\title{
Gemma
}

\section{¿FEMINISMOS CON MALA FOLLÁ?: UNA APROXIMACIÓN ETNOGRÁFICA A LOS TRANSFEMINISMOS DE LA CIUDAD DE GRANADA}

Diego Mendoza Albalat

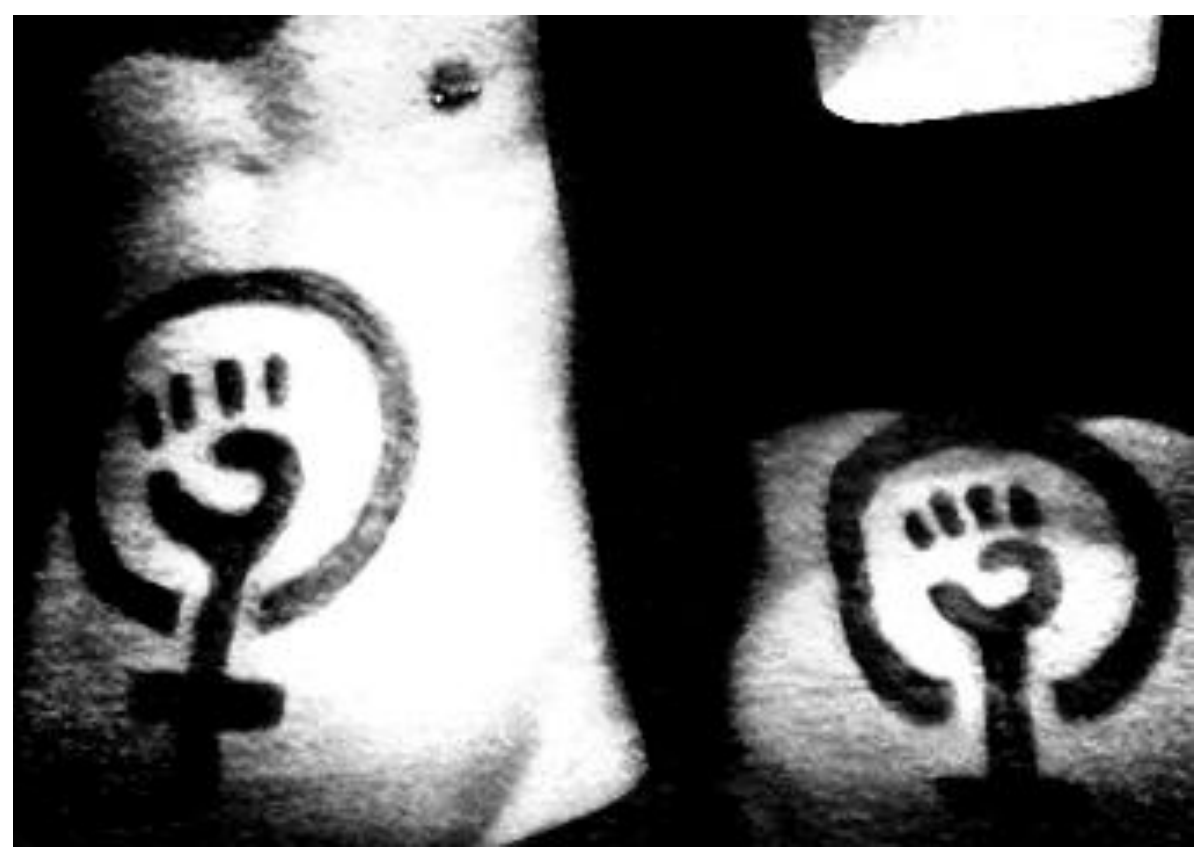




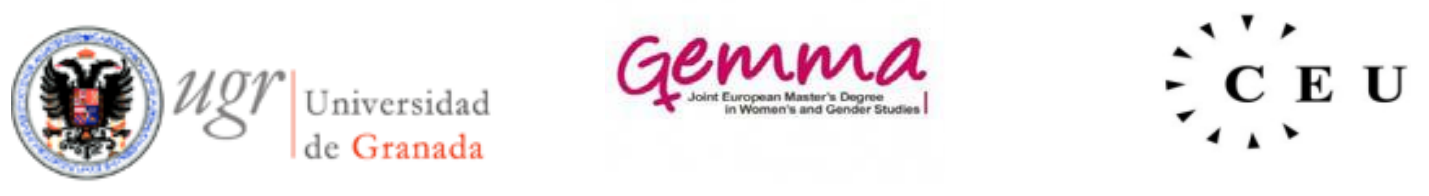

\title{
¿FEMINISMOS CON MALA FOLLÁ?: UNA APROXIMACIÓN ETNOGRÁFICA A LOS TRANSFEMINISMOS DE LA CIUDAD DE GRANADA
}

\author{
Diego Mendoza Albalat
}

\author{
Directora \\ Carmen Gregorio Gil \\ Profesora Titular de Antropología Social \\ Directora del Departamento de Antropología Social \\ Universidad de Granada \\ Directora de Apoyo \\ Eszter Timár \\ Department of Gender Studies \\ CEU of Budapest
}

Granada, Septiembre de 2015

Imagen Portada: Manifiesto PIGS

Carmen Fernández Moraga 


\title{
¿FEMINISMOS CON MALA FOLLÁ?: UNA APROXIMACIÓN ETNOGRÁFICA A LOS TRANSFEMINISMOS DE LA CIUDAD DE GRANADA
}

\author{
Diego Mendoza Albalat
}

\author{
Directora \\ Carmen Gregorio Gil \\ Profesora Titular de Antropología Social \\ Directora del Departamento de Antropología Social \\ Universidad de Granada \\ Directora de Apoyo \\ Eszter Timár \\ Department of Gender Studies \\ CEU of Budapest
}

Granada, Septiembre de 2015

Firma de Aprobación:

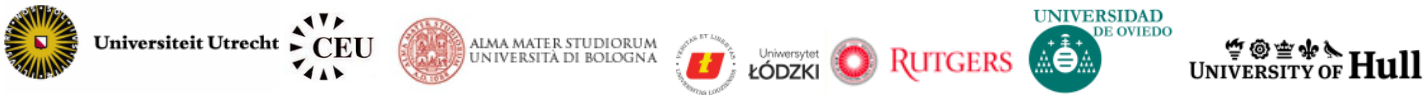




\section{RESUMEN}

El desarrollo de las teorías y prácticas queer han planteado nuevos interrogantes dentro de los movimientos feministas. Los temas relacionados con la deconstrucción de las identidades, la problematización del sujeto político de representación y reivindicación del feminismo o las políticas articuladas en torno a la no normatividad son algunos de los desafíos que lo queer introduce en el seno de los feminismos. El presente proyecto de investigación indaga sobre la recepción de las mencionadas teorías y prácticas en el Estado español, específicamente en el contexto de la ciudad de Granada. La lectura y contextualización de estas teorías y prácticas junto al creciente interés sobre las cuestiones Trans por parte de los feminismos han posibilitado el surgimiento del llamado transfeminismo. Un feminismo creativo, reivindicativo y cuestionador cuyas representaciones, como por ejemplo el pornoterrorismo, se alejan de prácticas feministas más clásicas.

A través de la metodología autoetnográfica me he aproximado a diferentes realidades transfeministas que están emergiendo en la ciudad de Granada con el fin de comprender las prácticas, discursos y producciones culturales que este movimiento está desarrollando. Asumiendo la hipótesis de conocimientos situados de Haraway, este proyecto contribuye al cuestionamiento de la supuesta objetividad positivista de la ciencia. Se asume, de esta manera, una objetividad feminista, situada, encarnada y parcial. Desde mi posición situada híbrida y junto a dos experiencias locales, Manada Salvaje y La Fábrika Crítica, he recogido diferentes aspectos que sirven como notas para acercarnos a una realidad compleja, alegre, rebelde y combativa como es la realidad transfeminista granadina.

\section{ABSTRACT}

The development of queer theories and practices has posed new questions within feminist movements. Issues related to the deconstruction of identities, to the problematization of feminism's political subject of representation and claim or to the policies articulated around the "non-normative", are some of the challenges that queer discourses and activisms have introduced into feminisms. This research project investigates the reception of these theories and practices in the Spanish state, specifically in the context of the city of Granada. Their readings and contextualization, together with feminisms' growing interest in Trans issues, have made possible the emergence of the so-called transfeminism. A creative, assertive and questioning feminism whose representations, as the pornterrorism, move away from the more traditional feminist practices.

Through the auto-ethnographical method I approached different transfeminist realities emerging in the city of Granada in order to understand the practices, discourses and cultural productions that this movement is developing. Assuming the hypothesis of situated knowledge of Haraway, this project contributes to the questioning of the supposed positivist objectivity of science. It is assumed, in this way, a feminist, situated, embodied and partial objectivity. From my situated and hybrid position, along with two local experiences, Manada Salvaje and La Fábrika Crítica, I collected different aspects that serve as notes to approach a complex, cheerful, rebellious and combative reality such as the transfeminist one in Granada. 


\section{AGRADECIMIENTOS}

"Gracias a Dios soy atea."

(Acción poética) $)^{1}$

Decía José Martí que "la gratitud como ciertas flores, no se da en la altura y mejor reverdece en la tierra buena de los humildes". Yo quiero comenzar este texto dando las gracias a todas las personas que han hecho posible que esté hoy aquí escribiendo esto y de esta manera.

Quiero agradecer a toda mi familia el apoyo recibido a lo largo de estos años. Gracias por esos valores que he aprendido con vosotrxs. Especialmente a mi madre, a mi padre y a mi hermana por comprenderme y por respetar cada decisión que he tomado en este periplo vital. Sé que no es fácil "entenderme" cuando vivimos en un contexto profundamente rural. Aunque la ciudad nos hace "libres", en lo rural yo he aprendido la solidaridad, el compartir y el respeto a las cosas simples de la vida.

Gracias también a todxs Ixs amigxs de mi tierra, por sus afectos, cuestionamientos, debates y críticas que me han hecho desarrollar argumentos para explicar, de una manera sencilla, la complejidad de la "burbuja perra" en la que vivo.

A mi familia "Charra", con ellxs y con la "perspectiva sociológica" que adquirí durante esos años, comencé a posicionarme más críticamente ante este sistema que regula nuestras existencias. Por nuestras fiestas, excursiones, diálogos y por el carácter contestatario, gracias.

A mi familia "Granaína", la de antes y la de ahora, por darme las alas para ser (estar) como soy, por llevarme a esos lugares "oscuros, lúgubres, electrónicos y hippyosos" fuera de esta realidad donde nos hemos dejado sentir en plena comodidad.

A mi familia "Checa", la Erasmus y la autóctona, por enseñarme que con locura esta vida merece más la pena. Por nuestras viajes balcánicos. Por acogerme cuando más precarix era, por la intensidad vivida. También a las gentes locas y rebeldes conocidas en Budapest.

A LA MANADA DE PERRAS por las revoluciones cotidianas, por las experiencias vividas, por las luchas que me han llevado a estar hoy aquí. A las "Marcelinas" por enseñarme a batallar cantando, por construir un común combativo desde las singularidades y las afinidades. A Las Perras Marcelinas, por todos esos momentos de charlas, cervezas, revoluciones, alegrías infinitas, Ilantos, gracias familia. A Manada Salvaje por ser un descubrimiento hermoso y enseñarme a luchar desde el amor y el deseo. A La Fábrika Crítica, a La Jimmy, por tantas y tantas cosas aprendidas, deconstruidas, por mostrarme cómo se construye performativamente lo impensable y lo pecaminoso.

Al caracol sureño y norteño que me acompaña, gracias por dejarte "queerizar", gracias por "agroecologizarme", por llevarme al trance con cada mirada, baile, cuerpo, escucha y cuidado.

\footnotetext{
${ }^{1}$ Frase de un grafiti en el mirador de San Miguel Alto en Granada.

2 José Julián Martí Pérez fue un político, escritor, pensador, filósofo, poeta y periodista cubano fundador del Partido Revolucionario Cubano y luchador por la independencia de Cuba.
} 
Y cómo no, gracias a mi directora, Carmen Gregorio Gil, por enseñarme a politizar las metodologías, por mostrarme "otras" formas de mirar y escribir, por su apoyo y valoración durante este tiempo. También al resto de profesorxs críticxs que se sienten en soledad. Nosotrxs también estamos ahí para revolucionar. 


\section{ÍNDICE}

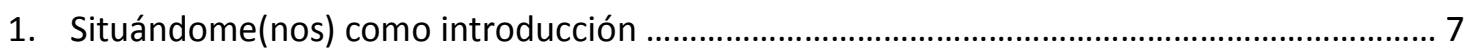

1.1 Autobigrafiar(se) para encontrar mi objeto de estudio ............................................. 9

1.1.1 La (de)construcción de mi género .......................................................... 10

1.1.2 Deviniendo Perra Marcelina .................................................................... 14

1.1.3 La manada como objeto de estudio ..................................................... 19

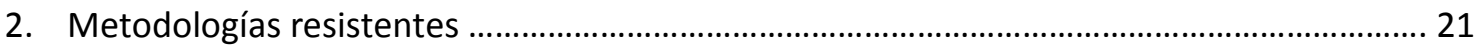

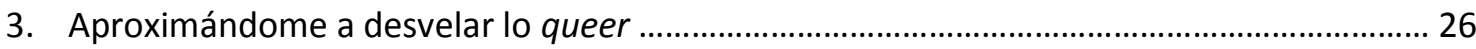

3.1 La resignificación como poder queer ………................................................................. 27

3.2 Sujetos y políticas queer .......................................................................................... 29

3.3 Recepción de las teorías queer en el Estado español: tejiendo genealogías transfeministas

4. Transfeminismos: desde lo escrito, escuchado, observado y experimentado. La teoría queer como base para la comprensión

4.1 Relectura transfeminista de lo queer 38

4.2 Sexo y género como procesos performativos: nuestra "madre" Butler 39

4.3 ¡Bollera, precaria y revolucionaria!: Wittig y la crítica transfeminista a la heteronormatividad

4.4 Bebemos de los fluidos de Foucault y Preciado: la politización transfeminista de la sexualidad y del cuerpo

4. 5 Inclusión de las cuestiones trans

4.6 Desarrollo de una perspectiva interseccional 46

4.7 Situando el pornoterrorismo y el postporno como políticas transfeministas 48

5. Pensando lo común en el contexto del capitalismo gore: la sostenibilidad de la vida y la vulnerabilidad del cuerpo 51

5.1 La vulnerabilidad del cuerpo en el centro del debate 52

6. Acercamiento a dos experiencias situadas: Manada Salvaje y La Fábrika Crítica. Mi construcción del discurso colectivo de la manada ........................................................................... 54

6.1 De lo personal a lo político o al revés: buscando las rutas hacia la Manada Salvaje.. 56

6.2 La construcción de una Fábrika (Crítica) que no aliena, no explota, no controla ni vigila 70

7. Reflexiones finales 81

8. Bibliografía 86 


\section{SITUÁNDOME(NOS) COMO INTRODUCCIÓN}

"Todos somos quimeras, híbridos teorizados y fabricados de máquina y organismo."

(Haraway, 1995, p. 254)

El presente texto es un híbrido como yo $\mathrm{mismx}^{3}$. Es o pretende ser la nueva mestiza de Anzaldúa, el cruce de las fronteras. Es el cyborg de Haraway o el becoming-intersectional assemblage de Puar. Es la combinación entre la escritura formal, la académica y la activista o la militante. Es o pretende ser la escritura de las revistas "científicas" y la de los blogs y manifiestos. La de las clases y tutorías y la de las asambleas, talleres y manifestaciones. Es o pretende ser la escritura de la observación y la de la participante. La de la investigación y la de la acción. Es o pretende ser la escritura de la reflexión y la de la materialización. La de la razón y la de la emoción. La de la energía y la calma. La iluminación y el bloqueo, el desvelo y la luz cegadora. Es o pretende ser la escritura del tránsito, el nomadismo y la mutación. La de lo personal y la de lo político. También la de lo teórico y lo pragmático. La de las idas y las venidas. La del ¿yo? Y el nosotrxs. La de lo colectivo y lo ¿individual? La del amor (no romántico) y la de la rabia. La lucha, la revolución, la memoria y la nostalgia. La del recuerdo, el presente y ¿̇el futuro? La de la pasión y la ternura. La del deseo y la represión. La de lo urbano y lo rural. La del sexo salvaje, el placer y el dolor. La de los encuentros y desencuentros. La de los cuidados y los descuidados. Alegrías y perdones. La del primer dildo y la del te quiero después de un polvo. La de la intensidad y el sosiego. La de la rave ${ }^{4}$, el trance y la de la lectura relajada con un café. La de las performances, los disfraces, los accesorios y complementos. La de las plumas. La de las becas y la precariedad.

Es o pretende ser un desafío a las concepciones binarias del mundo. El mestizaje siempre es hermoso. También pretende ser un cuestionamiento a una forma de producir conocimiento, la de la objetividad positivista.

\footnotetext{
${ }^{3}$ A partir de este momento utilizaré " $X$ " como estrategia de resistencia feminista que pretende desestabilizar y denunciar el uso del lenguaje sexista y heteronormativo. Esto constituye una negativa a utilizar el masculino genérico, el masculino como referente de lo universal; es una crítica al androcentrismo presente en nuestras sociedades. Otro de los objetivos de la utilización de " $X$ " es el de visibilizar e incluir a aquellas descripciones autoidentitarias que no se enmarcan dentro de los límites y categorías binarias de lo masculino y lo femenino. También utilizaré " $X$ " cuando hable de mí en los momentos en los que no me piense en masculino. En el caso de que se utilice el masculino o el femenino se debe a que Ixs sujetxs a Ixs que me refiero se sienten cómodxs con dichas identificaciones.

4 "Las raves o free parties son fiestas que se realizan en lugares fortuitos e insospechados y promueven una cultura hedonista alejada de las categorías ajustadas para el ocio consumista y uniforme de las metrópolis capitalistas" (Gil, 2011, p. 251).
} 
Sin anular mi cuerpo, mis deseos, mis intenciones, en este texto me desnudo y me visto varias veces. Me desnudan y me visten, me quitan la ropa y me abrigan mis compañerxs ${ }^{5}$ con sus reflexiones, afectos, cuestionamientos, críticas y cuidados.

Desde un lugar situado, me he aproximado a una realidad colectiva desde la que nos enunciamos, nos articulamos y nos constituimos como sujetxs rebeldes que nos negamos a vivir en un mundo que intenta oprimir y regular nuestros deseos, afectos $y$ formas relacionarnos con Ixs demás.

Para esta aproximación he tenido que mirarme, construirme y deconstruirme. Mirar a mis compañerxs, sentirlxs y dejar que sus discursos se incorporen y se mezclen con los míos.

Para comprendernxs, he tenido que "viajar" cientos de kilómetros con el objetivo de observar cómo ciertas prácticas y discursos se han expandido víricamente y nos contagiado con sus posiciones de resistencia ante los regímenes de lo "normal". Estoy hablando de las prácticas queer, que aunque no nacieron en nuestro contexto, se han asentado hibridándose con nuestra historia, nuestras genealogías, encarnándose en nosotrxs, cuerpos poco patrióticos y poco normativos.

Estas prácticas se han instalado para (esperemos) nunca más desaparecer dando forma a un movimiento que ha cambiado nuestra forma de estar y de comprender el mundo: el transfeminismo(s). A través de mi experiencia corporal, de mis vivencias y a través del sentir de mis compañerxs he intentado recoger diferentes contenidos a los que damos vida. Contenidos que se erigen como críticos ante un sistema heteropatriarcal y capitalista que pretende controlar nuestras vidas. Dos experiencias situadas: Manada Salvaje y La Fábrika Crítica me guiarán en la escritura y en la aproximación a este movimiento.

No están todxs Ixs que son, ni tampoco están todos los contenidos que este movimiento encarna. El espacio y el tiempo que se ajustan al formato de la tesina no me han permitido más. Quizá sea un texto poco teórico para lo que la Academia espera, y poco pragmático para lo que la militancia requiere. Pero desde mi posición situada híbrida, espero haber resuelto esta encrucijada en la que me encuentro, recogiendo diferentes aspectos que sirvan como notas para acercarnos a dicha realidad alegre, rebelde y combativa.

\footnotetext{
${ }^{5} \mathrm{~A}$ lo largo del texto me referiré con los términos compañerxs o nosotrxs al conjunto de sujetxs queer y transfeministas que juntxs hemos creado diferentes "micro manadas de perras" a través de las cuales articulamos nuestras luchas y nos han permitido desarrollar diferentes estrategias de resistencia y de empoderamiento. Cuando estos conceptos encarnen otros significados serán explicitados.
} 
Es el cierre (o así espero que sea) de un ciclo. Un ciclo intenso que da pie a la apertura de otros nuevos. Una ¿conclusión?, más bien unas reflexiones finales. Nada puede concluir. Todo (como yo $\operatorname{mismx}$ ) está en constante tránsito, en constante devenir. Hoy escribo esto, mañana ya veremos.

\subsection{Autobigrafiar(se) para encontrar mi objeto de estudio}

"No reivindico la feminidad de las chicas buenas, sino la de las perras malas. Una feminidad extrema, radical, subversiva, espectacular, insurgente, explosiva, paródica, sucia, nunca impecable, cabreada, despeinada, de rímel corrido, bastarda, desfasada, perdida, prestada, robada, extraviada, excesiva, exaltada, borde, canalla, viciosa barriobajera, impostora..."

(Itziar Ziga, 2009, pp. 34-35)

Recuerdo la primera vez que escuché hablar sobre las teorías queer. Estábamos descansando en la terraza de la cafetería de la facultad de Trabajo Social cuando un compañero dijo que iba a hacer un trabajo sobre las teorías queer, "aquellas que dicen que no existen hombres ni mujeres, que todo es una construcción social". A mí, me llamaron tanto la atención sus palabras que cuando terminé el café, me fui a la biblioteca de la facultad de Sociología y Ciencias Políticas, introduje en el buscador la palabra queer y encontré el libro El laberinto Queer. La Identidad en tiempos de neoliberalismo, de Susana López Penedo. En aquellos momentos no fui consciente de lo que esa palabra (queer), esas teorías y esas prácticas harían conmigo, de que acabarían por penetrar(me) y constituir mi cuerpo, mi manera de estar, habitar y entender el mundo.

Aquellos eran tiempos de ilusión, de rabia política, de ganas de cambio. El proceso de repolitización que estaba sufriendo durante el movimiento del 15M en Granada se cruzó con el proceso de mi propia revolución sexual. Asambleas, manifestaciones, debates, diálogos, charlas, okupaciones, reapropiaciones del espacio público (aquel que nos roban y privatizan). Deseos, fluidos, cuerpos otros, energías, movimientos, intensidad, dudas, cuestiones, se encarnan dando forma a mi cuerpo para nunca más desprenderse de mí.

En aquel momento, comencé a tener sexo con "tíos", bueno, con uno. Ahora ya no lo soy, él tampoco. $\mathrm{O}$ al menos no lo soy de la misma forma en que lo era antes. Ahora soy una perra. Perra salvaje en manada ${ }^{6}$. Pero hasta llegar aquí, mucho ha llovido, mucho ha cambiado, muchas horas de reflexión, conversaciones, cervezas, sexo... Quizás sea conveniente empezar por el principio.

\footnotetext{
${ }^{6}$ Para una interpretación política, subversiva, profunda de Perra y de La Manada véase Ziga (2009).
} 


\subsubsection{La (de)construcción de mi género ${ }^{7}$}

"Mi hombría es aceptarme diferente, ser cobarde es mucho más duro; yo no pongo la otra mejilla, pongo el culo compañero... y esa es mi venganza."

(Pedro Lemebel, 2000, p. $85^{8}$ )

Ya desde pequeño era un niño al que algunas personas definirían como no normativo, "un mariquita" para el resto de la sociedad. Además de disfrutar con los juguetes que tradicionalmente en nuestras sociedades occidentales se imponen a los niños, me gustaba jugar con muñecas, intercambiar hojas de papel y bailar las Spice Girls; yo era Mel B o "la negra" como decíamos en esos tiempos (ahora intuyo que empaticé con la performance desde muy joven).

En el seno de una familia de trabajadorxs del campo, (mis abuelxs lo fueron, mi madre y padre también lo son), crecí en un pueblo del norte de Extremadura de poco más de 500 habitantes donde los valores tradicionales, la religión, el conservadurismo se respiraba en todos los rincones, aun creyéndonos que porque la mayoría de los años de "democracia" los socialistas ostentaran la alcaldía del pueblo y el poder en la región extremeña, vivíamos en una tierra "progre". Quiero mencionar esto, pues mi relación con la política comenzó a desarrollarse incluso antes de que yo naciera, al igual que pasó con mi género. Mi madre, además de agricultora, ama de casa, me transmitió la conciencia social que ha perdurado hasta el momento, aunque se ha ido transformando y construyendo a lo largo de estos años. Mi padre fue el alcalde del pueblo desde antes de mi nacimiento y hasta no hace muchos años mantuvo ese cargo.

Mi relación con las "mujeres" ${ }^{9}$ ha sido siempre muy estrecha. Mi madre, mis abuelas, mis tías, primas, amigas y hermana han ocupado la mayor parte de mi tiempo y mis pensamientos a lo largo de la vida. Estos factores que configuran mi contexto social más temprano propiciaron mi interés por las cuestiones de género vinculado al interés por las desigualdades sociales y por la política ${ }^{10}$.

\footnotetext{
${ }^{7}$ Agradezco a la profesora Victoria Robles San Juan el espacio que nos permitió escribir desde la autobiografía, del cual extraigo algunos fragmentos de este texto.

${ }^{8}$ Esta frase pertenece al Manifiesto Hablo por mi diferencia y fue leído por primera vez en un acto político de la izquierda en Santiago de Chile en 1986. Puede consultarse en Lemebel (2000).

${ }^{9}$ Entiéndase por mujeres una categoría socialmente construida, no monolítica, ni cerrada, en la que intervienen diversos factores políticos, culturales, económicos, sexuales, etc. en su construcción, y que varía en el tiempo y en el espacio. Para una explicación más detallada de la construcción de la categoría mujeres véase Beauvoir (1998) [1949].

${ }^{10}$ Interesante definición de política aporta Kate Millett (2010) [1969] en Política Sexual. Ella entiende la política como "el conjunto de relaciones y compromisos estructurados de acuerdo con el poder, en
} 
No recuerdo exactamente el primer momento en el que algún niño me denominó (heterodesignó) "mariquita". Recuerdo que fueron varias ocasiones, unas más dolorosas, otras menos, pues yo simplemente hacía lo que en aquel momento me gustaba hacer, al principio sin cuestionarme si lo que hacía estaba bien o mal. Luego me vi obligado a repensar si estaba haciendo lo correcto, si debía cambiar y comportarme como el resto de la sociedad me estaba diciendo. Aunque en esos momentos no era consciente de la misma manera que ahora, puedo observar la violencia que la sociedad ejercía contra mí, y contra aquellxs que por alguna razón u otra se alejaban de la norma. Frases como "los niños no lloran", "eso de jugar con muñecas es de niñas", "si siempre estás con la niñas eres un mariquita" están cargadas de violencia. Considero que aquellas "inocentes" frases funcionarían como lo que Foucault (2009) entiende por dispositivo de control o disciplina ${ }^{11}$, maquinaria necesaria para el despliegue del biopoder o de la biopolítica de la población ${ }^{12}$. Pretendían que fuese dócil y útil para el sistema heteropatriarcal. Pero lo que yo voy a plasmar en estas líneas no es una historia victimista, ni de tristezas, ni pasividad (por suerte o qué sé yo por qué, no es la mía). Lo que yo voy a contar aquí es una historia (la mía) de reapropiaciones, resignificaciones y empoderamiento. Una historia que no sería posible contarla de esta manera sin la influencia de muchas personas con quienes he aprendido a politizarla y a dotarla de un sentido teórico y político.

Cuando nací, la institución médico-científica (el hospital de Plasencia) determinó mi sexo, mi futuro "ser", mi futuro "yo" en función de las diferencias sexuales percibidas visualmente con otrxs sujetxs $\sin$ "pene" ${ }^{\prime 13}$. De esta forma, me impusieron una identidad, construyeron mi cuerpo a partir de una simple frase como "ha sido niño". ¡Me encarcelaron sin pedir opinión! A

virtud de los cuales un grupo de personas queda bajo el control de otro grupo" (p. 67). Yo quiero entender la política en el sentido de transformación social, de transformación de las relaciones de poder; no en el sentido pervertido de la palabra. Entiéndase que esta perversión generada por quienes ostentan el poder se caracteriza por el bipartidismo y la creencia de que el voto es la única y deseable forma de participar políticamente.

${ }^{11}$ Entiéndase por disciplinas los "métodos que permiten el control minucioso de las operaciones del cuerpo, que garantizan la sujeción constante de sus fuerzas y les imponen una relación de docilidadutilidad" (Foucault, (2009) [1975], p. 141).

${ }^{12}$ Foucault señala que "las disciplinas del cuerpo y las regulaciones de la población constituyen los dos polos alrededor de los cuales se desarrolló la organización del poder sobre la vida" (1998 [1976], p.83). Sobre el concepto de biopoder me centraré más adelante.

${ }^{13}$ Siguiendo las ideas de Preciado, utilizo el término pene, y no el de falo pues este último pertenece a la retórica psicoanalítica y yo prefiero centrarme más en la materialidad de los cuerpos. Véase la entrevista a Preciado por Alejandro Jodorowsky en https://www.youtube.com/watch?v=M4k98oLXAml. En el mismo sentido que hablo de la institución médica, Nuria Gregori realiza un análisis crítico de los protocolos y tratamientos médicos que se aplican a las personas intersexuales. La autora no duda en afirmar que "la anatomía o la morfología genital será el marcador primero y principal para decidir el sexo futuro del recién nacido" (2006, p. 108). Esta construcción de los sexos responde a la lógica normalizadora de occidente que sólo concibe dos posibles sexos y patologiza aquello que se aleja de las categorías binarias. 
partir de ese momento, un conjunto de imposiciones condicionaron el resto de mi vida, se instalaron en mi cuerpo, el cual no sería inteligible en sociedad si no es a través de esta marca de género. Miles de años de opresión, de dominación, de estructuras económicas y políticas, de significados, de subordinación penetraron en lo más profundo de mi ser constituyendo mi alma ${ }^{14}$ de la cual será muy difícil escapar.

En los días y meses siguientes, el resto de instituciones (familia, estado, escuela, etc.) se encargaron del resto. A través del nombre, de los juguetes o de la ropa, continuaron "adiestrándome", imponiéndome una serie de normas que debería seguir el resto de mi vida si no quería sufrir los castigos de la penalidad disciplinaria. Además de construir mi sexo e imponerme un género, me enseñaron que eso era una cosa natural y biológica, contra la que no podía hacer nada si quisiera modificarla. Ahora sé que nada de esto es verdad, sino que es fruto del mandato de la matriz de inteligibilidad imperante en nuestra sociedad, la matriz heterosexual, la cual no permite entender mi cuerpo si no es a través de la marca del género. Gracias a unas cuantas lecturas feministas, descubrí que aquello que me enseñaron como natural, innato o biológico no lo es tanto como nos contaron.

Comencé a performar la masculinidad. Interioricé el ideal normativo y me consideré un niño. Esto me otorgó una serie de privilegios superiores al de mis compañeras ("sujetxs sin pene") que he utilizado en diversas ocasiones; en otras, los he rechazado de una manera consciente o inconsciente. Aún sigo trabajando en ello, en desaprender privilegios. También interioricé otro ideal normativo, el de "ser heterosexual", o mejor dicho, como señala Óscar Guasch el de "estar heterosexual" ${ }^{15}$ (2000, p. 34) que también me otorgó una serie de privilegios superiores al de mis compañerxs que "estaban homosexuales". Gracias a la educación de mi familia, en especial de mi madre, estas interiorizaciones no fueron tan profundas como la norma exige que sea.

Esta masculinidad que fui construyendo, que fui performando, quizá sea más preciso nombrarla como aquella que Conell describe como masculinidades subordinadas ${ }^{16}$; aun reconociendo que diversos mecanismos que utilicé para construirla fueron marcados por los códigos de género y de la heteronormatividad, como puede ser el asco, cuyo fin era conservar

\footnotetext{
${ }^{14}$ Para un análisis más detallado del alma véase Foucault (2009 [1975], p. 36).

${ }^{15}$ Desde un posicionamiento relativista donde las cosas no son en sí mismas, sino en función del contexto en el que se construyen, bajo la óptica de este autor sería más conveniente decir que las personas están heterosexuales, están homosexuales, etc. dando cuenta de la posibilidad de transformaciones.

${ }^{16}$ Entiéndase aquellas masculinidades "que quedarían ubicadas en la parte más baja de una jerarquía entre hombres, y respecto a las que suele darse una confusión simbólica con la feminidad, lo que puede suponer diferentes grados de exclusión social" Conell citado en Esteban (2003).
} 
de esta manera una identidad heterosexual. Como advierte Vendrell, lo interesante de este proceso es que "lo que nos daba asco puede que empiece a atraernos dado que casi todo lo que nos da asco es susceptible de erotización, introduciéndose así en otro registro emocional basado en otro tipo de reacción" (2003, p. 41). Puede que eso me haya pasado a mí. Doy fe de ello, me ha pasado.

Llegué a Granada para continuar los estudios de Sociología y esto hizo que siguiera profundizando en el camino de cuestionamientos personales, teóricos, políticos, sociales que había comenzado durante los primeros meses del estudio de esta disciplina en la Universidad de Salamanca. Coincidiendo con lo que yo vivencié como la revolución del $15 \mathrm{M}^{17}$ en Granada, experimenté lo que podríamos entender como una revolución sexual personal, rechazando así, una serie de privilegios y asumiendo las consecuencias que esto supone en diversos contextos (en otros no las asumí tan alegremente). Teresa del Valle hablaría en estos momentos de hitos (1995, p. 284). Dos grandes hitos que marcarán el resto de mi existencia.

El toparme con textos sobre las teorías queer durante esta misma época hizo que comenzase a entender mi sexualidad, mi género, mi cuerpo de una manera muy diferente a como los había entendido con anterioridad. Poco a poco iba profundizando en estos asuntos y me di cuenta que esas palabras estaban respondiendo numerosas cuestiones que yo tenía y que habitaban en mis pensamientos. Supuso un intersticio (Del Valle, 1995, p. 286) para mí, un momento de claridad, de clarividencia. ¡Qué pena no haberlo descubierto antes! A partir de ese momento, combinando el proceso del $15 \mathrm{M}$, el proceso de revolución sexual y lo que descubrí en las teorías queer, empecé a deconstruir conscientemente muchas de aquellas imposiciones, normas, reglas, conductas, saberes, relaciones de poder, formas de relacionarme con Ixs demás y conmigo mismx que había interiorizado los años anteriores.

Comencé a posicionarme críticamente sobre la construcción de mi identidad, a adoptar una mirada crítica ante los procesos de construcción de ficciones identitarias. De esta manera, entendí que mi género es algo plástico, maleable, transformable, corrompible. La esencia de mi género es precisamente su inestabilidad, su permeabilidad. Mi género ansía el cambio, la transformación. Es una performance de la que yo soy protagonista y de la que pretendo

\footnotetext{
${ }^{17}$ Yo entendí este proceso como una revolución pues consiguió entusiasmar, emocionar, el despertar de las conciencias, la creencia de que otra forma de organización es posible. La apropiación de los espacios públicos por parte de la ciudadanía, mostró que se exigía otra forma de hacer política a través de asambleas abiertas. Aún se me ponen los pelos de punta cuando recuerdo aquellos primero días en los que creímos que las cosas podían cambiar, "si no nos dejáis soñar, no os dejaremos dormir" quedará grabada en la memoria de muchas de las personas que en este proceso participamos.
} 
escribir el guión. Trascenderlo es el objetivo de este camino vital. Aún sigo en este proceso quizá inalcanzable.

Tras la aceptación de una beca Erasmus, fui a Praga a terminar mis estudios. Ciudad mágica, cuento de hadas que se transforma durante cada noche para albergar la máxima "oscuridad" en sus bares, pubs o discotecas. Fue un periodo poco intenso en cuanto a mi actividad política. Además de acudir a la universidad, me dediqué a viajar por Europa del Este con un grupillo de "Erasmus alternativxs", mi familia Erasmus. Yo seguía en mi proceso de (de) construcción personal.

Al final de ese mismo curso, comencé a conocer a la que posteriormente sería mi familia checa. Un grupo de lokxs festivalerxs y también disidentes sexuales cuyo lugar de reunión era el Wakata, nuestra segunda casa. Mi año fue tan emocionante y fructífero que una vez terminada la carrera, decidí quedarme en Praga para buscarme las habichuelas. Las cosas en el Estado español no estaban nada bien. Qué voy a contar que no sepamos. Desempleo, privatizaciones, represión, anulación de derechos conseguidos, etc. Un panorama que invitaba a pasar una larga temporada fuera del estado. Fueron meses duros durante la búsqueda de trabajo. Mi amiga Carmen quiso emprender esta experiencia conmigo y se vino a probar suerte. Durante esos meses encarnamos lo que es ser inmigrantes en búsqueda de trabajo. Gracias a esta familia checa todo fue un poco más fácil y ameno. Encontramos trabajo como relaciones públicas. Explotación y venta del cuerpo describirían esa experiencia laboral. Como lo conseguido no era suficiente para vivir, lo combinábamos con un currillo en un almacén.

\subsubsection{Deviniendo Perra Marcelina}

"Insértame los dedos hasta que me toques el corazón (comprobarás que no late). Dilátame, muéveme, empálame, hazme no distinguir la frontera entre el dolor y el placer..."

(Diana J. Torres, 2011, p. 166 ${ }^{18}$ )

Intentando salir de la precariedad absoluta en la que vivía en Praga, solicité la entrada en el máster GEMMA sobre estudios de las mujeres y de género. En aquel momento compartía cama con Carmen y con nuestra "madre" checa, Mondieu. Vivíamos en un pequeño apartamento (eufemismo) en el barrio de Zizkov. Un barrio obrero, habitado por inmigrantes, trabajadorxs y estudiantes. Éramos felices. Otras veces no tanto. La precariedad hacía que cualquier recurso que encontrara unx de Ixs tres, se compartiera entre nosotrxs: comida, cervezas, tabaco y demás víveres necesarios para nuestra supervivencia. Intensidad sería la

\footnotetext{
${ }^{18}$ Versos del poema Metasexual de Diana J. Torres que puede consultarse en Torres (2011).
} 
palabra que define mi última etapa en la ciudad de Bohemia. El suicidio de uno de nuestrxs amigxs, la falta de recursos, la explotación laboral, los litros de cervezas y todo tipo de fiestas me impulsaron a tomar la decisión de solicitar la entrada en el máster con el objetivo de seguir conservando mi salud emocional.

En septiembre comencé el máster. Los nervios del primer día de clase fueron desapareciendo tras la ronda de presentaciones de Ixs compañerxs. Desde el primer momento noté que había algo especial en ese grupo de feministas locas y diversas de todas las clases, nacionalidades, intereses y sexualidades. El descanso, el cigarro y el café sirvieron para que comenzase a hablar con la que iba a ser una de mis mejores compañeras y pieza fundamental de la manada, La Small Marce. Madrileña, con poderío y una presencia y discurso que no dejan indiferente a nadie. La compañera italiana se acercó a nosotrxs en cuanto encontró la oportunidad pues nos había echado el ojo durante la ronda de presentaciones ya que nosotrxs también habíamos expresado nuestro interés por las cuestiones queer. Descarada, reflexiva, crítica, grande por dentro y por fuera. Esta perra sería la Big Marce dentro de nuestra manada.

Durante los siguientes días se fue configurando una gran y diversa piña entre todxs Ixs compañerxs del máster. Hablábamos de violencias, opresiones, deseos, sexo, géneros, transgresiones, situándonos cada unx de nosotrxs a través de nuestras vivencias. De manera fluida y sin premeditarlo fuimos construyendo un sujeto político colectivo de reivindicación: Marcelina. "Marcelina somos todas, Marcelina no estás sola", gritábamos en cada momento de euforia, risas o reivindicación. Este sujeto múltiple, diverso e inclusivo surge de la resignificación de una canción mejicana que la compañera Andrea tarareaba con su pequeña jarana. Una contrafacta ${ }^{19}$ al queer style de la canción del Colás en la que Ixs sujetxs principales eran el travesti Nicolás y la bollera Marcelina ${ }^{20}$. Fue y sigue siendo nuestro himno principal. A partir de esa primera experiencia creativa, comenzamos a crear contrafactas de numerosas canciones.

Teníamos ganas de organizarnos políticamente. De conocer experiencias feministas que estaban trabajando en la ciudad de Granada y de sacar a la calle aquellos temas a los que dábamos mil vueltas durante las clases. De esta forma, constituimos la Asamblea Identidades en Tránsito con muy diversas subjetividades. Formada principalmente por Ixs compañerxs del máster, pero también por diferentes compañerxs que llevaban años militando en Granada.

\footnotetext{
${ }^{19}$ La contrafacta es una estrategia musical que consiste en transformar la letra de una canción manteniendo la melodía original. Diversos colectivos utilizan esta estrategia de resignificación como resistencia.

${ }^{20}$ La letra de la contrafacta puede verse en el anexo no5.
} 
Este es el caso de la que posteriormente sería La Marce Bio, perra, animalista, vegeta, bruja y energética aportaba la experiencia de 11 años habitando y militando en la ciudad granadina. Eran tiempos de lucha por la defensa de derechos como el del aborto, la educación pública o contra las medidas de represión impuestas por el gobierno reaccionario y conservador del Partido Popular.

Al terminar una de nuestras primeras asambleas fuimos al Sonho, un bar alternativo de calle Elvira donde el grupo de performances Manada Salvaje ${ }^{21}$ iba a realizar una performance pornoterrorista. Era la primera vez que veía una performance pornoterrorista en directo y me pareció brutal aquella forma de lucha política. Así, comencé a interesarme mucho más por este tipo de estrategias políticas y subversivas. Me entraron muchas ganas de utilizar mi cuerpo como herramienta política para de esta forma denunciar, criticar, cuestionar a todas las instituciones del poder que durante siglos de historia se habían apropiado de nuestras carnes. Iglesia, Estado, Ciencia, Mercados estaban en el punto de mira.

A los pocos días, un compañero feminista (Cato) me dijo que una amiga suya estaba preparando un proyecto fotográfico sobre parafilias y que necesitaba "tíos" para sus fotos pues le estaba siendo difícil encontrar "modelos con polla". La verdad que no me lo pensé mucho. Me dijo que apareceríamos juntxs en algunas fotos y que sería un gran favor para ella. Le dije que sí sin mucha reflexión. Durante los días previos a la sesión de fotos las dudas y cuestionamientos comenzaron a robarme pensamientos. Sería la primera vez que utilizaría mi cuerpo de esta manera y me preguntaba si estaría preparadx para ello. ¿Y si se me empalma durante el reportaje? ¿Y si no se me empalma y la fotógrafa necesita erecciones? Cuando conocí a la fotógrafa, La Fany, comenzaron a desaparecer aquellos nervios con los que me dirigía a la sesión. Su arte y acento sevillano me transmitieron la confianza que necesitaba. Me estuvo explicando el proyecto tranquilamente y las fotos en las que quería que apareciese.

En esa misma casa estaba el compañero Alex quien me enseñó las láminas de los dibujos eróticos que estaba preparando para su libro Haz el amor y también la guerra ${ }^{22}$. Para mí fue un proceso muy empoderante. Sí, empoderamiento es la palabra con la que definiría mis

\footnotetext{
${ }^{21}$ El audio con la voz de Diana (la pornoterrorista) reventaba los altavoces del lugar, sexo entre "mujeres", sexo entre bolleras, rosarios que salen del "coño" a la voz de "mi cuerpo es mío" no dejaron indiferente a nadie durante esa noche.

${ }^{22}$ El libro puede consultarse en http://trafikantedecolores.webnode.es/otrascreaciones/haz-el-amor-ytambien-la-guerra/
} 
sensaciones. Cuando el proyecto "Monstruos"23 salió a la luz, aluciné con la potencia política de aquellas fotos: cuerpos Trans ${ }^{24}$, fluidos, monjas que se excitan con la figura de Cristo, barbies que penetran vaginas, etc. Un coctel molotov que explotaba en las manos del heteropatriarcado.

Durante estos meses de militancia conjunta en Identidades en Tránsito, nos dimos cuenta de que teníamos múltiples y variados objetivos e intereses. Creímos que la publicación del libro Cásate y sé sumisa, editado por el arzobispado de Granada, merecía una respuesta. La nuestra fue una acción callejera, de las que más nos gustan. Hicimos pintadas por las calles de la ciudad con el lema "Sumisa ni en tu misa". Interpreto que la gestión de dicha acción fue el punto final de nuestra asamblea. Diferentes voces y pensamientos hicieron que decidiésemos disolver nuestra asamblea de manera amigable, pacífica, entre risas y cervezas. Algunx de nosotrxs decidió trabajar con la Asamblea Feminista Unitaria ${ }^{25}$ con la que habíamos colaborado estos meses anteriores. Cuatro de nosotrxs decidimos formar un colectivo queer-transfeminista: Las Perras Marcelinas ${ }^{26}$. La Big Marce, La Small Marce, la Marce Bio y la Marce Barbuda (yo) dispuestas a perrear por las calles de Granada. De esta manera, nos fuimos acercando a la realidad activista de la ciudad y conocimos a quienes serían nuestras mejores aliadas y compañeras de manada, las perras de la Fábrika Crítika $^{27}$ y Eskándalo Púbico ${ }^{28}$.

Con ellas hice mi primer taller postporno. "Mi sexualidad es una creación artística"29, "Pelea de perras" ${ }^{30}$ o "In the Wood" fueron varios de los vídeos sobre los que estuvimos reflexionando, cuestionando y repensando alternativas formas de la sexualidad, de las identidades, de los placeres o deseos. Gran ejemplo de cómo hacer postporno con útiles del hogar lo desarrolló unx de Ixs compañerxs sexualizando una fregona. La fregona, símbolo del patriarcado, fue resignificada en algo muy placentero y divertido. Poco a poco me iba metiendo más

23 El proyecto Monstruos puede consultarse en el blog de Estefanía García: http://nadaquerascar.webnode.es/proyectos/monstruos/ 0 en la revista feminista: http://www.pikaramagazine.com/2014/05/monstruos/

${ }^{24}$ Fernández y Araneta (2013) hacen una distinción entre las personas transexuales quienes creen que se encuentran en un cuerpo equivocado y pretenden transitar de un género a otro; y las personas trans que incluiría una serie más amplia de subjetividades que no se enmarcarían en los códigos binarios corporales ni de género.

25 Información sobre la Asamblea Feminista Unitaria puede consultarse en https://www.facebook.com/asamblea.feministaunitaria?fref=ts

${ }^{26}$ El Manifiesto en tránsito de Las Perras Marcelinas puede verse en el Anexo no1.

${ }^{27}$ La página web de La Fábrika Crítica puede consultarse en http://lafabrikacritica.com/

${ }^{28}$ El blog de Eskándalo Púbico puede consultarse en https://eskandalopubico.wordpress.com/

29 Información y resumen del documental puede consultarse en http://www.lucysombra.org/archives/category/pornologia/mi-sexualidad-es-una-creacion-artistica

${ }^{30}$ El vídeo "Pelea de perras" y otros videos postpornográficos pueden consultarse en la página web del colectivo Post-Op. http://postop-postporno.tumblr.com/videos 
profundamente en este mundo de la subversión transfeminista. La presentación de la revista digital Artillería para Trasnochadxs de Eskándalo Púbico en el centro social okupado Lxs 15 gatxs (actualmente resignificado en La Redonda) hizo que me diese cuenta de que verdaderamente esta era mi lucha y esta era mi manada. El trabajo detrás de la barra con La Jimmy, la perra con más arte de la manada, fue mi pequeña colaboración en esas jornadas. Con ellxs también conocí a Steffi y sus proyectos de resistencias visuales ${ }^{31}$, y a los colectivos Quimera Rosa ${ }^{32}$ e Ideas destroying muros ${ }^{33}$ quienes hicieron diferentes performances en el mismo centro social.

Fueron meses de mucha intensidad política. Asambleas, manifestaciones, talleres, acciones ocupaban la mayor parte de nuestros pensamientos ${ }^{34}$. Todas las semanas había múltiples actos de resistencia y reivindicación política. Otro de esos momentos emocionantes en los que participamos Las Perras Marcelinas fue el escrache a Gallardón que realizamos junto a las compañeras de la Asamblea Feminista Unitaria. Algunx de nosotrxs conseguimos colarnos en el acto en el que el ministro iba a participar y al grito de "Aborto libre y gratuito", "Mi cuerpo, mi vida, mi forma de follar no se arrodillan al sistema patriarcal", "Vamos a quemar la conferencia episcopal (...) por machista y patriarcal" irrumpimos con toda la rabia y fuerza que emanaban de nuestros cuerpos.

La militancia en Las Perras Marcelinas constituyó un antes y un después en mí. Hito constitutivo de quien soy ahora. Con ellxs aprendí, compartí, reí, lloré, me empoderé siempre acompañadxs de nuestras queridas cervezas como principal herramienta para la producción creativa. Horas de cervezas en el Cascabel, uno de nuestros antros preferidos, sirvieron de mucho. El taller que impartimos en las jornadas feministas organizadas por la CNT de Granada $^{35}$ fue una de nuestras mayores apuestas. Queríamos trabajar sobre las múltiples conexiones que encontrábamos entre el heteropatriarcado y el capitalismo ${ }^{36}$.

\footnotetext{
${ }^{31}$ Estos proyectos pueden consultarse en https://otraeskuelitadefoto.wordpress.com/

${ }^{32}$ Para más información sobre el colectivo véase http://quimerarosa.net/

${ }^{33}$ Información sobre el colectivo puede consultarse en: http://www.ideadestroyingmuros.info/

${ }^{34}$ Granada estaba viviendo una efervescencia política callejera contra los recortes, las privatizaciones, la represión, la defensa del aborto o la lucha por un proceso constituyente tras la abdicación del monarca (ver como la bandera españolista caía de la mítica rotonda del Triunfo y era sustituida por una gran bandera republicana, fue uno de los momentos más emocionantes de mi vida).

${ }^{35}$ Puede consultarse http://granada.cnt.es/

${ }^{36}$ Durante el taller al que llamamos "Mi cuerpo, mi vida, mi forma de follar: estrategias para la autodeterminación sexual y afectiva" desarrollamos colectivamente una perspectiva interseccional tratando diferentes sistemas opresores como la raza, el género, la sexualidad, la clase, la diversidad funcional que posibilitan la normatividad/no normatividad, inclusiones/exclusiones, privilegios y jerarquías que configuran nuestros cuerpos, nuestras vidas encarnadas. Cómo desarrollar estrategias de
} 
No sabíamos que ese sería nuestro último taller como Perras Marcelinas, pero esa es otra historia que no me interesa contar. Sólo señalo, siguiendo a Itziar Ziga, que "así somos la gente rebelde, no paramos nunca de escindirnos" (2009, p. 31).

Estas experiencias y vivencias hicieron que me sintiera cómodx al pensarme como queer. Soy hombre por imposición médica; soy queer por posicionamiento político, como estrategia de lucha. Al igual que lo personal es político, lo político es personal. Aun asumiendo y comprendiendo diferentes críticas que se desarrollan en torno al concepto queer en nuestro contexto, yo sigo encontrando mucha potencialidad política en describirme como tal. Hasta el momento, no quiero rechazar ese término. Todo esto está muy conectado con la historia que acabo de contar. Para mí, lo queer significó un punto de inflexión en mi vida. Estas teorías y prácticas me orientaron a explicarme quién soy (estoy) y quien quiero ser (estar). Desde mi óptica, siguen teniendo validez política y personal. Además considero que el pensarse como queer tiene un gran poder desestabilizador en la sociedad, en las mentes de Ixs demás. Les haces cuestionar qué es eso. “¿De qué estás hablando?”, “¿Estás un poco loco, no?”, “iEres un vicioso!", "No quieras que todo el mundo comparta tus paranoias", "Que interesante eso que dices, ¿me lo puedes volver a explicar?", "Tendremos que leer sobre eso que cuentas", son algunas de las contestaciones que yo me he encontrado al expresarme como queer.

\subsubsection{La manada como objeto de estudio}

"Porque nuestros deseos y afectos destruyen tu sistema heteropatriarcal y capitalista."

(Nota del diario de campo, 12 de mayo de 2015)

Tras el año en Granada cargado de rabia y fuerza política, me fui a Budapest a continuar los estudios del máster. Iba con dos de mis compañerxs, La Small y La Big Marce. Allí nos topamos con la $\mathrm{CEU}^{37}$, universidad privada fundada por George Soros, universidad al estilo yanqui. El choque cultural fue para Ixs tres brutal. La carga de trabajo impedía que pudiésemos militar fuera de la estructura y cada día unx de nosotrxs desesperaba. Encontramos poco espacio para desarrollar estrategias de resistencia. Uno de estos espacios, fue la creación del Manifiesto $P I G S^{38}$. Uno de los requisitos de la asignatura Intersectionality consistía en la elaboración de un

resistencia colectiva y de autodeterminación sexual y afectiva era el objetivo principal de nuestro taller. Fotos sobre este taller y sobre Las Perras Marcelinas pueden verse en el Anexo $\mathrm{n}$ ㅇ. 6 .

${ }^{37}$ Central European University of Budapest.

${ }^{38}$ El acrónimo P.I.G.S es utilizado por los países hegemónicos de la Unión Europea para describir a los países más afectados por la crisis financiera (Portugal, Italia, Grecia y España). En ocasiones también se incluye a Irlanda (P.I.I.G.S). 
vídeo $^{39}$ tratando temas relacionados con la interseccionalidad. Desde el principio lo teníamos claro. Queríamos expresar cómo nuestra subjetividad PIGS se había fortalecido como consecuencia de nuestra estancia en dicha universidad. Claro está que lo teníamos que hacer de una manera creativa, ¿̇qué mejor que una performance utilizando nuestro cuerpo como herramienta política?

Ante esta situación, poco a poco iba surgiendo una necesidad personal y política de reconectarme con la militancia y el activismo de la ciudad de Granada. Quería seguir en el proceso de deconstrucción y empoderamiento que había sido tan profundo el año anterior. ¿Qué mejor manera que volver a conectarme con el activismo transfeminista que haciendo el trabajo final del máster sobre el propio movimiento?

Todo lo que en estas páginas he contado es lo que me ha llevado a elaborar mi objeto de estudio fundado en intereses políticos, personales y teóricos sobre el activismo transfeminista granadino, mi propio activismo. El objetivo principal de esta tesina es la recogida de diferentes experiencias transfeministas; discursos, prácticas y producciones culturales que se vienen desarrollando desde los transfeminismos en la ciudad de Granada. ¿Qué entendemos por transfeminismos? ¿Cómo se analiza el término queer, sus teorías y prácticas desde estas experiencias? ¿Nos sentimos cómodxs con este concepto? ¿Qué motivaciones nos han llevado a militar en este movimiento? ¿Sobre qué ejes se articula el activismo? ¿De qué manera lo hacemos? ¿Qué lugar ocupamos dentro de los feminismos? ¿Qué problematizamos del movimiento? ¿Qué estrategias de resistencia desarrollamos? ¿Cuáles son nuestras alianzas? ¿Qué herramientas políticas utilizamos? ¿Cuáles son sus representaciones? ¿Qué subjetividades encarnan este movimiento? ¿Qué importancia tiene el cuerpo en nuestras prácticas? ¿Qué lugar ocupa el pornoterrorismo dentro del movimiento? ¿Cuáles son nuestras reflexiones sobre las problemáticas comunes que el sistema heteropatriarcal y capitalista genera?

Estas son algunas de las preguntas con las que inicialmente comienzo esta investigación. El resto de interrogantes fueron apareciendo durante el propio proceso, pues he pretendido que fuese una investigación abierta y colaborativa, múltiple y fluida, con el objetivo de no forzar hipótesis, sino dejar que sean Ixs propixs informantes protagonistas de este proyecto.

\footnotetext{
${ }^{39}$ El video del Manifiesto PIGS puede consultarse en https://www.youtube.com/watch?v=F69KFgC0h7s. Es fruto de intensos debates y diálogos entre lxs compañerxs Big Marce, Small Marce, Laura, Maddy y Tom (compañerxs transfeministas de Italia). La grabación y montaje del vídeo se realizó por la compañera italiana Paola. A través de este video pretendíamos resignificar el concepto P.I.G.S, reapropiarnos de él y utilizarlo como estrategia de resistencia. La traducción del Manifesto PIGS puede verse en el anexo no 3. Fotos sobre el Manifiesto PIGS pueden verse en el Anexo no 7.
} 
Por tanto, es un proyecto que emerge desde los márgenes. Considero que escuchar a los márgenes es un acto político de gran importancia. Siguiendo a Sedgwick, el autor Steven Epstein (1996) señala que las teorías queer pretenden analizar los márgenes, experiencias situadas en lo contra hegemónico con el objetivo de interpretar de manera profunda la sociedad en su conjunto, cómo funciona y qué mecanismos utiliza. Este trabajo se apoya en dicha filosofía. Los márgenes serán quienes desvelen diferentes mecanismos sociales y cómo operan en la realidad social.

El visibilizar discursos y prácticas no normativas, subversivas del orden establecido me pone de la misma manera que me interesa teórica y políticamente. Este proyecto trata sobre resistencias, sobre activismo y militancia, sobre posicionamientos contra-hegemónicos. Si lo personal es político, también es teórico (Gregorio, 2006). Pretendo producir conocimiento construido desde lo subjetivo y lo colaborativo. Conocimientos encarnados, que surgen desde las entrañas, desde los cuerpos. Cuerpos inapropiados, cuerpos otros, cuerpos abyectos, terroristas y monstruosos serán mi principal herramienta de trabajo.

De esta manera, será un proyecto situado, parcial, encarnado y transgresor de la supuesta objetividad cientificista y positivista que peca de patriarcal y colonialista. No pretendo extraer leyes universales, ni verdades absolutas. Quiero aproximarme a una realidad emergente y combativa que subvierte los límites de lo normativo, formal o lo políticamente correcto. Esta será mi aproximación sobre dicha realidad, acercamiento construido colectivamente. Puede haber más aproximaciones, tantas como investigadorxs sociales o personas que presten su interés en dichas experiencias. Esta es la mía.

\section{METODOLOGÍAS RESISTENTES}

Con todo lo anteriormente dicho, considero que la metodología más apropiada para aproximarme a mi objeto de estudio es la etnografía con perspectiva feminista. Dicha metodología me proporciona las herramientas epistemológicas, teóricas, conceptuales y técnicas necesarias para este acercamiento al activismo, a una realidad social que es múltiple y diversa. Desde mi perspectiva deconstruccionista, soy consciente de la importancia del lenguaje a la hora de construir la realidad. Asumo que será mi óptica la que construya la realidad a la que pretendo acercarme ${ }^{40}$.

\footnotetext{
40 Una postura antirrealista según la distinción de modelos epistemológicos desarrollada por Hammersley y Atkinson (1994 citado en Ferrándiz, 2011).
} 
Por ello, he comenzado aproximándome a esta realidad social desde la autobiografía, haciendo un recorrido sobre los hitos y demás acontecimientos personales que me han llevado a militar en este movimiento, pues siguiendo a Teresa del Valle, encuentro gran potencialidad política en hablar y escribir desde lo "auto" puesto que "en la manera que revela muchos datos e interpretaciones que en general se escapan de los relatos considerados científicos, la autobiografía es una fuente excelente para un nuevo conocimiento y de ahí su importancia" (1995, p. 281). Entiendo con la autora "la autobiografía como un género subversivo" (Del Valle, 1995, p. 281) sobre el que la antropología feminista y la historia de las mujeres tienen mucho que aportar, mucho que extraer, mucho que desvelar, mucho que decir, muchas historias que visibilizar, mucho que ganar. Harding (1987) hablaría en estos momentos de rescatar las experiencias de las mujeres, yo prefiero hablar de rescatar las experiencias de las periferias ${ }^{41}$.

Es especialmente reveladora para mí la afirmación de José Antonio Fernández de la Rota y Monter cuando señala que "Nancy Scheper-Hughes sitúa su postura antropológica y su trabajo dentro del contexto de su propia vida" (2012, p. 132). Al igual que la antropóloga, pretendo que la propia militancia sea objeto de interés teórico, político y personal. Algo sobre lo que pensar, reflexionar y problematizar; algo sobre lo que aprender. De esta manera, suscribo la idea de Gregorio, Hernández y Apaolaza (2011) cuando entienden la etnografía como resistencia al concebirla como "un proceso de aprendizaje (interactivo) en el que el antropólogo o antropóloga aprende con otras personas" ${ }^{\text {"2 }}$.

De esta forma, entenderé la etnografía como un proceso interactivo de cuestionamientos constantes sobre aquello que parece obvio, que ha sido naturalizado, que ha sido somatizado. En este proceso se erige como fundamental una mirada especial a la hora de acercarme a la realidad social. Siguiendo a Del Valle entiendo por mirada:

Un conjunto de dispositivos, de habilidades y recursos que ponemos en práctica para conocer a través de la experiencia y mediante una actitud de apertura, la

\footnotetext{
${ }^{41}$ Afín a estos postulados Boaventura de Sousa Santos (2010) propone una nueva epistemología (del Sur) que se distancie de la del Norte global y que él describe como la doble sociología transgresiva de las ausencias y de las emergencias. A través de la sociología de las ausencias "se trata de transformar objetos imposibles en objetos posibles, objetos ausentes en objetos presentes" (2010, p. 22). Y a través de la sociología de las emergencias se pretende investigar "las alternativas que caben en el horizonte de las posibilidades concretas" (2010, p. 25). Frente a la lógica eurocéntrica, capitalista y colonialista, De Sousa Santos plantea una "ampliación simbólica de los saberes, prácticas y agentes que se identifiquen en ellos la tendencia de futuro" $(2010$, p. 26). El objetivo de las mismas es el aproximarse a "las versiones subalternas, silenciadas, marginalizadas de modernidad y de racionalidad, tanto occidentales como no occidentales" (2010, p. 21).

${ }^{42}$ Véase Simposio: Etnografiando resistencias, en el XII Congreso de Antropología: Lugares, Tiempos, Memoria. La Antropología Ibérica en el siglo XXI.
} 
diversidad de datos, interpretaciones, emociones, contradicciones, extrañezas, interrogantes como parte de lo que ofrece la inmersión en la situación elegida. $(2012)^{43}$

Es decir, esta mirada nos exige un ejercicio de extrañamiento, de problematización de lo que estamos observando, un ejercicio de distanciamiento, de interrogación persistente ante aquello que se presenta como normal. Esto implicaría dejar a un lado mis creencias, prejuicios, valoraciones culturales, ideas previas para llevar adelante una observación continuada en el tiempo.

En este proceso interactivo de extrañamiento yo seré objeto de mi propia interrogación, de ahí que la Autoetnografía sea específicamente la metodología más adecuada para este proyecto de investigación. Siguiendo el trabajo de algunas etnógrafas, he pretendido que el ejercicio de mirarse, de cuestionarse, de dejarse sentir a lo largo del proceso me orientara a la hora de delimitar mi objeto de estudio ${ }^{44}$. Como ya he señalado con anterioridad, mi pretensión es elaborar un proyecto abierto y en diálogo, flexible y permeable. La Autoetnografía me permitirá desarrollar debates teóricos y políticos en función de la interacción entre mis compañerxs y yo mismx.

Deseo que la reflexividad sea uno de los pilares fundamentales sobre el que se asiente esta investigación. Reconozco la influencia recíproca entre "mis sujetxs de estudio" y yo mismx. Esto implicará escribir la tesina en primera persona pero a varias voces. Al hacer una investigación sobre la propia militancia, no puedo escapar de "etnografiarme", de cuestionarme durante este proceso y de hablar desde mí. Con el objetivo de evitar ciertos cuestionamientos éticos, como puede ser la creencia de que encarno la portavocía del movimiento al registrar los diferentes discursos de estas experiencias transfeministas, pretendo que Ixs sujetxs de estudio jueguen un papel fundamental en el desarrollo de la investigación, y sean sus voces, sus gritos lo que se plasme en estas líneas.

Pretendo que mi enfoque se sitúe dentro de una perspectiva feminista de crítica y transgresión. Este enfoque implica dar voz a Ixs sujetxs de estudio para que ellxs sean creadorxs de sus propios discursos. Implica romper con las dicotomías entre sujeto/objeto y tratar a Ixs informantes como "sujetxs de conocimiento". Supone entender a nuestro objeto de estudio como sujetx de estudio con capacidad de crear prácticas, significados y sentido, con

$43 \mathrm{El}$ documento en línea puede consultarse en http://www.gazeta-antropologia.es/wpcontent/uploads/GA-28-3-10-TeresadelVallel.pdf

${ }^{44}$ Véase por ejemplo Wekker (2006), Espinosa (2010), Gregorio (2014). 
agencia y resistencia. El objetivo es diluir esta barrera, estas dicotomías y asumir que este proceso se desarrolla bajo un entramado de relaciones de poder que son fluidas, móviles y diversas.

Supone contextualizar y comprender el conocimiento que estamos construyendo tomándolo como un conocimiento histórico y asumiendo que existe una serie de relaciones de poder en función del género, la clase, la sexualidad, la edad, la raza, la etnia o la diversidad funcional entre otros ejes opresores que atraviesan las identidades de las personas en intersección. Sigo las ideas de Gregorio quien indica que:

La crítica feminista -en donde tendrán un papel protagonista las epistemólogas de las ciencias naturales - se señalará que el saber científico se construye en un espacio y tiempo determinado y, como consecuencia de su legitimidad para conceptualizar de forma universal la verdad y lo significativo, contribuye a justificar las relaciones de poder. (2006, p. 28)

Así, este proyecto de investigación pretende contribuir, en la misma senda que numerosos textos críticos, al cuestionamiento de la objetividad positivista. Idea reveladora para el feminismo es la que desarrolla Haraway cuando apuesta por "una doctrina de la objetividad encarnada que acomode proyectos de ciencia feminista paradójicos y críticos: la objetividad feminista significa, sencillamente, conocimientos situados" (Haraway, 1995, p. 234). De ahí deriva mi pretensión de no intentar extraer leyes universales que se extrapolen a otros contextos, sino generar un conocimiento contextual, parcial, situado, encarnado y producido desde los márgenes; en definitiva, un proyecto con objetividad feminista.

Con el objetivo de solventar de la mejor manera posible la cuestión de los diferentes puntos de vista y del análisis de los temas que he tratado con mis compañerxs, he tenido muy en cuenta la distinción emic-etic ${ }^{45}$.

Durante el período de estudio del máster GEMMA he tenido lo oportunidad de conocer diferentes trabajos y personas que en su afán por escuchar a los márgenes y producir conocimiento desde "otros" lugares me han conducido a optar por el uso de técnicas de

\footnotetext{
${ }^{45}$ Como señala Matilde Fernández Montes "Ios trabajos emic utilizan en su interpretación de los fenómenos estudiados categorías (conscientes o inconscientes) que son significativas para el sujeto o la colectividad que proporcionan los datos, mientras que el análisis etic parte de conceptos o categorías elaborados por el investigador o la colectividad a la que pertenece y por tanto no tienen por qué coincidir con las experiencias de tipo emic. (2010, p. 308)
} 
investigación participativas. Gracias a diferentes clases, tutorías y conversaciones con mi directora, Carmen Gregorio, he aprendido que la metodología es "política" y que un trabajo que pretende encarnar las características mencionadas implicaría la necesaria colaboración de mis compañerxs en la delimitación del proyecto. Por este motivo, y además inspirándome también en trabajos como el realizado por Precarias a la deriva, he pretendido que mis técnicas de obtención de datos hayan posibilitado la participación de mis compañerxs y su inclusión en la demarcación de los contenidos y las temáticas del proyecto.

Debido a diversas lecturas y reflexiones con algunas profesoras y compañerxs he comprendido que la forma de acercarnos a la realidad social, las herramientas que utilicemos, los compromisos adquiridos y la manera de relacionarnos con lxs demás tienen gran importancia en el resultado de la investigación. Así, los cambios metodológicos y conceptuales realizados durante el proceso investigador han sido dialogados con las personas que participan en la misma y la información obtenida ha sido devuelta a Ixs compañerxs antes de su defensa y publicación con el fin de consensuar lo que a continuación expondré.

He considerado interesante que la observación participante se constituyese como uno de los ejes principales del proceso metodológico puesto que el estar presente en el campo social facilita las condiciones necesarias de extrañamiento y reflexividad que exige la metodología etnográfica. Mirar, observar, capturar, reflexionar, interrogar(me) se establecen como procesos fundamentales dentro de mi investigación. Así, he pretendido que la observación participante, la combinación entre observar e interactuar, posibilite el surgimiento de nuevos interrogantes que han ido orientando el proceso de investigación.

Del Valle encuentra fundamental la importancia de los símbolos dentro del arte de observar. De este modo, señala que "el poder de los símbolos responde a los contenidos que se les asigne y al poder evocador que generen" (Del Valle, 2012) ${ }^{46}$. Por esta razón, fotografías, carteles, blogs, páginas web de diferentes colectivos transfeministas han tenido un importante valor a la hora de obtener significados de sus prácticas y discursos.

La observación se ha realizado principalmente en el espacio físico de La Fábrika Crítica puesto que es el lugar de encuentro por excelencia de las redes transfeministas de la ciudad. Han sido numerosas las asistencias a dicho espacio donde entre todxs hemos contribuido a generar un conocimiento colectivo a partir metodologías participativas: talleres, charlas, debates, cine-

${ }^{46} \mathrm{El}$ documento en línea puede consultarse en http://www.gazeta-antropologia.es/wpcontent/uploads/GA-28-3-10-TeresadelVallel.pdf 
forums, performances, jornadas, exposiciones, son algunos ejemplos de actividades sobre las que se nutre esta investigación.

Con el objetivo de profundizar sobre diferentes ámbitos donde la observación participante no me permitía llegar, he optado por realizar diversas entrevistas en profundidad (también recomendadas por mi directora). La principal pretensión de las mismas ha sido el intentar conocer diversos contenidos pertenecientes al terreno de lo subjetivo, de lo personal, de lo emocional de mis compañerxs. La politización y teorización de diversas experiencias personales son una constante en los movimientos feministas y el utilizar las entrevistas en profundidad con carácter abierto me ha permitido acercarme a los mencionados lugares personales intentando que las personas entrevistadas pudiesen expresarse libremente, prestando importancia a aquellos aspectos que ellxs mismxs quisieran enfatizar y así otorgarles el mayor protagonismo.

\section{APROXIMÁNDOME A DESVELAR LO QUEER}

"We are here, we are queer, we riot."

No tendría mucho sentido que pretendiese ofrecer una definición cerrada y estable del concepto queer cuando uno de los objetivos de esta investigación es seguir reflexionando sobre el significado de esta y otras palabras (como transfeminismo); seguir interrogando a los propios conceptos. Puesto que son creaciones lingüísticas, performativas, activistas que se resisten a la normalización y a la categorización, mi objetivo no es establecer una definición fija de la palabra. Sí que es cierto, que pretendo aproximarme a los contenidos, a los significados que dicho concepto encarna a través de diferentes teóricxs y activistas que han performado, escrito y hablado sobre lo queer. Algunx de ellxs participaron en los primeros colectivos queer $^{47}$ que surgieron en Estados Unidos durante finales de los años ochenta y los años noventa. Otras de las referencias que utilizaré son propias de nuestros contextos hispanos pues parte de la investigación se basa en entender cómo estas prácticas y teorías han aterrizado a este lado del océano.

\footnotetext{
${ }^{47}$ Como ejemplos significativos de estos colectivos podemos nombrar a ACT UP y a Queer Nation. EI primero de ellos, surge en Nueva York durante la crisis del sida con el objetivo de denunciar la homofobia y cuestionar las "medidas" del gobierno sobre la cuestión del sida. Unen arte y política a través de una postura radical. Sus prácticas inspirarán a numerosos colectivos queer de todo el mundo. Queer Nation surge en Nueva York en 1990. Sus prácticas críticas y radicales serán analizadas en el siguiente epígrafe. Estos colectivos estaban formados por disidentes sexuales, trabajadorxs sexuales, negrxs y otras minorías.
} 


\subsection{La resignificación como poder queer}

"Sí, QUEER puede ser una palabra brusca, pero es también una astuta e irónica arma que podemos robar de las manos de la homofobia y usarla contra ella."

(Queers leed esto ${ }^{48}$ )

Hasta no hace muchos años, queer era simplemente un insulto. Era la peor y más dolorosa palabra con que las sociedades angloparlantes pretendían describir a aquellxs que de una manera u otra se alejaban de la norma, principalmente de la norma sexual (la hetero). También era usual adjetivar con esta palabra a aquellxs que no se les podía encasillar en las identidades normativas binarias de género.

En castellano, queer se podría traducir como marica, tortillera, travelo, puta, mariquita, bollera, sarasa, camionera, bujarrón, palomo cojo, pierde aceite, sadomasoquista, fetichista, etc. Englobaría a una serie de sujetxs que por su disidencia sexual o de género no pueden escapar sin consecuencias de las técnicas de normalización del cuerpo y de la identidad de nuestra sociedad heterocentrada y androcéntrica. Más tarde profundizaremos sobre las consecuencias, logros y desventajas de esta traducción. Si etimológicamente queer quiere decir extraño, aquello que es raro, diferente, el insulto hizo que se relacionase con lo anormal, con lo desviado o lo torcido. La ideología dominante utiliza la injuria como un mecanismo de control de las subjetividades, como una tecnología de normalización. Todo aquel que se aleje de sus mandatos será golpeado por el contenido peyorativo de la palabra:

la palabra servía en realidad para trazar un límite al horizonte democrático: aquel que llamaba a otro "queer" se situaba a sí mismo sentado confortablemente en un sofá imaginario de la esfera pública en tranquilo intercambio comunicativo con sus iguales heterosexuales mientras expulsaba al "queer" más allá de los confines de lo humano. (Preciado, 2009, p. 16) ${ }^{49}$

Pero ¿qué ha pasado con esta palabra? Algo tan esperanzador que merece la pena ser explicado. Durante finales de los años ochenta, coincidiendo plenamente con la crisis del sida; con la crisis del feminismo blanco, heterosexual y de clase media que empieza a ser cuestionado por lesbianas, chicanas, feministas negras y transexuales; y con las políticas

\footnotetext{
${ }^{48}$ Queers leed esto (Queers read this) es un panfleto de autoría anónima que se repartió en la manifestación del orgullo de Nueva York de 1990 y se constituyó como el texto fundacional del grupo Queer Nation. Puede consultarse en Mérida (Ed.) (2009) o en el blog de la distribuidora Peligrosidad Social: https://distribuidorapeligrosidadsocial.wordpress.com/

${ }^{49}$ Este texto aparece en el número 1 de la revista digital Parole de Queer. Puede consultarse en https://www.scribd.com/fullscreen/79992238?access key=key-2164jancgcgodxmcd3jir
} 
integracionistas del movimiento $\mathrm{LGTB}^{50}$, un conjunto de micro grupos desobedientes del género y de la sexualidad en Norte América comienza a reapropiarse de la palabra queer para enunciarse desde ese lugar. Aquello que había servido como instrumento de control, de represión, de violencia y de opresión fue resignificado por diversos sujetxs y colectivos que se situaban en los márgenes de la sociedad heterocentrada. Al enunciarte desde estas posiciones, aquellxs que utilizaban dicha palabra con el objetivo del control y del dolor no pueden continuar con la misma estrategia, puesto quien se enunciaba como queer estaba completamente orgullosx de serlo. Decirte queer era (o es) un acto político. Un acto de rebeldía y un posicionamiento crítico, una forma combativa de estar en el mundo.

¿Qué supuso para estos microgrupos de sujetxs abyectos la resignificación de esta palabra? Sin duda alguna, empoderamiento. A través de deconstruir el contenido peyorativo de la palabra queer y dotarla de otros significados, el mismo hecho de reapropiación y resignificación supuso un empuje empoderante para estos microgrupos. Un lugar desde donde articular sus luchas frente a un sistema que les oprimía y les violentaba.

Butler señala que esto es posible debido a la "brecha entre el contexto original o la intención con la que un enunciado es dicho y los efectos que produce" $(1997, \text { p. } 14)^{51}$. Queer es un ejemplo de resignificación de manera positiva a través del tiempo de una injuria (hate speech). $Y$ es precisamente esta resignificación la que conduce al empoderamiento de aquellos grupos que se situaban en los márgenes. Este mecanismo "muestra cómo las palabras pueden, con el tiempo, disociarse de su poder para herir y ser recontextualizadas en modos más afirmativos" (Butler, 1997, p. 15) ${ }^{52}$. La autora continúa señalando que queer es un "recurso crítico en la lucha por rearticular los propios términos de la legitimidad simbólica y la inteligibilidad" (Butler, 1997, p. 3) 33 $^{53}$ He considerado oportuno comenzar explicando brevemente el proceso de transformación de significados que ha sufrido esta palabra porque dicha estrategia de resistencia, de apropiación y de resignificación será desarrollada en numerosas ocasiones por los colectivos queer y transfeministas en nuestro contexto como iremos viendo a lo largo del texto.

\footnotetext{
${ }^{50}$ Para un análisis exhaustivo del contexto del surgimiento de las prácticas y teorías queer véase Sáez, J. (2005). Sobre la crisis del sida y las estrategias de resistencia desarrolladas por el activismo véase Crimp (2003), Crimp (1987) y Bersani (1987). En el libro Otras inapropiables. Feminismos desde las fronteras (VV.AA, 2004) se recogen varios textos críticos del feminismo chicano y negro.

${ }^{51}$ Traducción propia.

52 Traducción propia.

${ }^{53}$ Traducción propia.
} 


\subsection{Sujetos y Políticas queer}

"La crisis del sida puso de manifiesto que la construcción social de los cuerpos, su represión, el ejercicio del poder, la homofobia, la exclusión social, el colonialismo, la lucha de clases, el racismo, el sistema de sexo y género, el heterocentrismo, etc., son fenómenos que se comunican entre sí."

(Javier Sáez, 2005, p. 69)

Un texto que ha sido clave para mí, para comprender lo queer, es la compilación de ensayos Fear of a Queer Planet: Queer Politics and Social Theory recogida por el teórico y activista Michael Warner. En la introducción a este texto, Warner (1994) señala como característica principal de lo queer la resistencia a los procesos de normalización y la extensión del significado de este concepto, indicando que abarca más allá de la disidencia sexual. Comenzando este escrito con la pregunta What do queers want? (1994, p. 7), Warner no duda en afirmar que no quieren sólo sexo, sino que:

toda persona quien se autodenomina como queer sabe de una forma u otra que su estigmatización está conectada al género, a la familia, a las nociones de libertad individual, al estado, al discurso público, al consumo y deseo, a la naturaleza y a la cultura, a la madurez, a las políticas reproductivas, a la fantasía racial y nacional, a la identidad de clase, a la verdad y a la confianza, a la censura, a la vida íntima y la exhibición social, al terror y a la violencia, al sistema de salud, y a las profundas normas culturales que constituyen el cuerpo. Ser queer significa luchar sobre estos asuntos todo el tiempo, localmente y poco a poco pero siempre con consecuencias. Esto significa ser capaz, más o menos articuladamente, de desafiar el entendimiento común de lo que significa la diferencia de género, o para qué está el estado, o lo que la "salud" implica, o lo que define la justicia, o lo que sería una buena relación con el medio ambiente del planeta. Los queers hacen un tipo de práctica social reflexiva justamente en encontrar las formas de ser queer. $(1994, \text { p.13) })^{54}$

De esta manera, se desmonta el mito de que la única preocupación queer es la sexualidad, aunque por supuesto, sin obviarla. Lo queer toma la sexualidad como pieza angular para formular y comprender los mecanismos sociales de control, normalización y opresión sobre los que se rigen nuestras sociedades. La sexualidad desde un punto de vista queer tendría repercusiones en la construcción de diferentes espacios de la vida social, de las instituciones y las normas sociales.

\footnotetext{
${ }^{54}$ Traducción propia.
} 
Debido a esta interpretación, "las luchas queer reclaman no sólo tolerancia o igualdad de estatus sino que desafían esas instituciones y valores" (Warner, 1993, p. 13) $)^{55}$ ya que el orden (hetero)sexual configura o condiciona las diferentes áreas de la vida social. En este sentido, Abelove $(2003)^{56}$, señala que alejándose de la lógica de la tolerancia y del interés específico por los derechos civiles para gays y lesbianas, las políticas queer, o las acciones queer son una respuesta a los incidentes homófobos, prestan atención a la visibilidad de prácticas, discursos y cuerpos no normativos y afirman no la marginación, sino la centralidad. El autor realiza un interesante paralelismo entre Walden ${ }^{57}$ y las políticas queer para señalar que Walden podría entenderse como la primera acción queer ya que se aleja de los discursos de la familia, el amor romántico, el matrimonio o los discursos conservadores.

En el mismo texto, el autor afirma que una acción "es una forma de hacer lo que es políticamente relevante contestando, a menudo sensacionalmente, el hastío producido por la disrupción de los discursos de familia, el amor, y el matrimonio, y también performando o actuando una reclamación de centralidad" $\left(2003\right.$, p. 40) ${ }^{58}$. Abelove (2003) señala que las acciones están muy conectadas con las performances. Así, considero que lo que el autor trata de decir es que una acción es una forma queer de actuar, de hacer, de performar.

En la misma línea, Epstein insiste en que lo queer hace referencia a una "política de la provocación, en la que los límites de la tolerancia liberal son constantemente empujados" $(1993, \text { p. } 153)^{59}$. Es decir, desde lo queer no se actúa desde una posición políticamente correcta que reclama la tolerancia, sino que se busca escandalizar, alborotar, perturbar, desconcertar, visibilizar(se $)^{60}$. Acciones cargadas de humor e ironía como estrategia de resistencia en contra de los regímenes de lo normal. Lo carnavalesco, la parodia, la sátira, la deconstrucción serán características constitutivas de las políticas queer (Gamson, 2002).

\footnotetext{
${ }^{55}$ Traducción propia.

${ }^{56}$ Henri Abelove es teórico y fue activista de Queer Nation.

${ }^{57}$ Walden es un libro escrito por Henri David Thoureau en 1854. Tuvo importante repercusión en la prensa estadounidense de la época y debido a sus contenidos que se alejaban de los ideales conservadores del amor, la familia o el matrimonio fueron tachados, tanto el libro como el autor, de excéntricos y de que promovían una filosofía del egoísmo. Una vez más, los discursos hegemónicos pretenden normalizar a través del hate speech o de la injuria marcando así a aquellas personas o discursos que se desvían de la norma.

${ }^{58}$ Traducción propia.

${ }^{59}$ Traducción propia.

${ }^{60}$ Tanto Epstein (1993) como Abelove (2003) indican que muchas de aquellas acciones que hacían los primero grupos queer consistían en acudir a locales, bares, restaurantes frecuentados altamente por heterosexuales o de claro carácter heterocentrado y comenzar a darse besos entre personas que en apariencia mantienen el mismo género, es decir, prácticas Kissing. Otra de las prácticas usuales en los grupos queer era el Outing, que consiste en revelar la homosexualidad de alguna figura pública.
} 
Siguiendo a Epstein (1996), lo queer podría recoger a aquellas subjetividades no normativas, gays, lesbianas, bisexuales, drag Queens/Kings, transexuales, etc. Un término inclusivo que pretende aglutinar formas de estar en el mundo subversivas y politizadas. De esta forma, lo queer haría referencia a una compleja política "co-sexual" en la que todxs participarían en igualdad de condiciones (Epstein, 1996). Queer se opone y cuestiona el término gay por referirse al sujeto blanco homosexual de clase media (Gamson, 2002), categoría excluyente que homogeniza e invisibiliza otras formas habitar el mundo.

Lo queer funcionaría como un marcador diferencial generacional (Epstein, 1996; Gamson, 2002). Muchas de las establecidas comunidades de gays y lesbianas no se sentían cómodas con el uso de este término por considerarlo la expresión del opresor. Señalaban que la juventud no había sufrido el dolor, la exclusión, la violencia de la misma manera que la generación anterior (Gamson, 2002). Sin embargo, la juventud queer se apropia de este término injurioso y peyorativo con el objetivo de deconstruirlo y llenarlo de otro contenido; un contenido rebelde, transgresor y combativo.

En relación con la característica anterior, podemos señalar que lo queer se constituye como un posicionamiento antiasimilacionista en el sistema heteronormativo y capitalista. La posición política queer es un rechazo a las estrategias de inclusión en el sistema por parte de los grupos mainstream de gays y lesbianas (Epstein, 1996). En este sentido, José Esteban Muñoz (2009) realiza una interesante distinción entre el queer time (tiempo queer) y el straight time (tiempo hetero) con el que se relacionarían las políticas de los grupos de gays y lesbianas mainstream. El autor conceptualiza el straight time a partir de su relación con el presente. El explícito pragmatismo de las reivindicaciones de los actuales colectivos LGTB de Norte América y las políticas de identidad, como la lucha por el matrimonio homosexual, conducen a Esteban Muñoz a entender este movimiento y su agenda política dentro del straight time ${ }^{61}$.

El autor indica que el objetivo de la pragmática performance del matrimonio es el acceso al capital y al reconocimiento. Esta naturalización del tiempo presente es caracterizada por la ausencia de una crítica sobre las desigualdades sociales. Grupos activistas queer como Gay Shame manifiestan una "oposición a la homormatividad del activismo gay y lesbiano pro derechos rechazando el matrimonio como el penúltimo logro en la carrera por la igualdad de

\footnotetext{
${ }^{61}$ La filosofía que podemos leer detrás de esta agenda es la lógica del "aquí y ahora". La lógica asimilacionista que esta agenda encarna es la lógica de la inclusión en el sistema capitalista y heteronormativo. Para Esteban Muñoz (2009) el principal símbolo de estas reivindicaciones es la performance del matrimonio.
} 
derechos" (Weiss, 2008, p. 88) ${ }^{62}$. Weiss muestra como estos grupos afirman que "el matrimonio es la institución central del misógino y racista sistema de dominación y opresión conocido como heterosexualidad" (2008, p. 88). En contraste con la reivindicación del derecho al matrimonio del movimiento LGTB, "Ias voces queers se oponen totalmente a esta ruta argumentando que permitir al estado entrar en sus vidas privadas significa la aceptación de la heteronormatividad y sus instituciones de poder y control" (López, 2012, p. 249) ${ }^{63}$.

Por otro lado, Esteban Muñoz define el queer time a través de su lógica de futuridad. Lo queer "no es todavía conocido" (2009, p. 21) , $^{64}$ es el horizonte utópico que podemos seguir. Lo queer como utopía ${ }^{65}$ supone una crítica a la naturalización del presente. Lejos de los pragmáticos y antiutópicos discursos de las lesbianas y gays sobre el matrimonio, en su imaginario, Esteban Muñoz conceptualiza el potencial de lo queer como horizonte. Imagina el tiempo queer como un trabajo colectivo sobre el futuro cuyo objetivo es crear una lógica colectiva de futuro alejándose de la individualista lógica del presente. Así, lo queer constituye una crítica al proceso de mercantilización de las políticas gays y lesbianas, una crítica a lo que se viene conociendo como "capitalismo rosa".

Estas asunciones constituyen un cuestionamiento de las políticas de identidad entrando de lleno en lo que Gamson (2002) teoriza como el "Queer dilemma". Lo queer cuestiona la estabilidad, la naturalización y fijeza de las categorías sociales. Gamson indica que "el reto por excelencia que plantean las prácticas queer no es sólo el cuestionamiento del contenido de las identidades colectivas, sino el cuestionamiento de la unidad, la estabilidad, la viabilidad y la utilidad política de las identidades sexuales" (2002, p. 154). Las políticas queer pretenden deconstruir las categorías esencialistas de mujer/hombre, hetero/homo y atraviesan el debate contemporáneo sobre las políticas de identidad. ¿Cómo desarrollar políticas y reivindicaciones cuestionando y deconstruyendo las identidades sociales? Como Gamson muestra "las categorías de identidad fijas son tanto la base de la opresión como del poder político" (2002, p. 143).

Desde una perspectiva queer, las identidades son construcciones sociales, fruto de procesos históricos y culturales que se fraguan bajo un entramado de relaciones de poder. Lo queer insiste en que la fluidez sería una característica principal de las identidades sexuales y de

\footnotetext{
${ }^{62}$ Traducción propia.

${ }^{63}$ Traducción propia.

${ }^{64}$ Traducción propia.

${ }^{65}$ Existen diferentes posiciones entre lxs teóricxs queer sobre la futuridad, la utopía o el queer time. Para una revisión profunda de dichos debates véase Caserio; Edelman; Halberstam; Esteban Muñoz; Dean (2006).
} 
género (Epstein, 1996). No tiene sentido organizar el mundo en categorías binarias y dicotómicas (hombre/mujer, homosexual/heterosexual, etc.) pues no daría cuenta de la multiplicidad de formas de estar en el mundo. Lo queer critica la lógica cartesiana del pensamiento binario, puesto que esta lógica implica necesariamente jerarquía y exclusiones. Los binarismos de género son opresivos (Gamson, 2002), cuyo objetivo es la normalización, el control y orden social. ¿Qué tipo de estrategias de resistencia al poder podríamos desarrollar desde estos postulados? Las prácticas queer "nos informan de que las fronteras seguras y las identidades estables no son necesarias en general, sino de forma específica" (Gamson, 2002, p. 165).

Siguiendo a Preciado (2005), lo queer no niega la identidad en sí misma, sino que pretende desontologizarla, desnaturalizarla, implementando diferentes estrategias de resistencias a los procesos de normalización. Preciado habla de multitudes para referirse a Ixs sujetxs queer, y sin negar la influencia del poder en la construcción de las identidades, señala la capacidad de Ixs mismxs para "intervenir en los dispositivos biotecnológicos de producción de subjetividad sexual” (2005, p. 161). De esta forma, algunas de las estrategias políticas que llevan a cabo estas multitudes son:

"Des-identificación. Surge de las bolleras que no son mujeres, de los maricas que no son hombres, de los trans que no son ni hombres ni mujeres" (Preciado, 2005, p. 161). Las multitudes queer hacen una lectura de las ideas de Wittig cuando señala que "las lesbianas no son mujeres", e implementan estrategias de des-identificación con el objetivo de construir diferentes formas de habitar el mundo al margen de las identidades normativas de hombre y mujer.

"Identificaciones estratégicas" (Preciado, 2005, p. 162). Injurias, insultos, palabras peyorativas van a ser apropiadas por las multitudes queer, van a ser resignificadas, dotadas de nuevos contenidos y significados resistentes a la norma con el objetivo de enunciarse desde esas posiciones abyectas. Preciado afirma que las multitudes queer "hacen un uso radical de los recursos políticos de la producción performativa de las identidades desviadas" (2005, p. 162) para oponerse al sujeto universal privilegiado por excelencia blanco, colonial, burgués y heterosexual. Marica, bollera, negra, precaria, migrante, trans serán posiciones estratégicas desde donde enunciarse y resistir. Preciado recalca que "estas multitudes no comparten la desconfianza -insistimos en ello- de Foucault, Wittig y Deleuze hacia la identidad como lugar de acción política, a pesar de sus diferentes formas de analizar el poder y la opresión" (2005, p. 162). 
“Reconversión de las tecnologías del cuerpo: Los cuerpos de las multitudes queer son también reapropiaciones (...) de los discursos de la medicina anatómica y de la pornografía, entre otros, que han construido el cuerpo hetero y el cuerpo desviado modernos" (Preciado, 2005, p. 163). La multiplicidad de cuerpos no normativos muestra la diversidad de estrategias corporales resistentes a la normalización: travestis, trans, bolleras-camioneras, maricas emplumadas y llenas de purpurina, cuerpos cyborg son ejemplos de un largo etcétera de corporalidades subversivas.

"Desontologización del sujeto de la política sexual" (Preciado, 2005, p. 164). A partir de los años 90, esta multitud pone en entredicho las concepciones esencialistas de los anteriores movimientos identitarios, cuestionan la unidad, la estabilidad, la fijeza, la naturalidad de los sujetxs de reivindicación del feminismo o del movimiento homosexual afirmando la diversidad de factores que construyen las subjetividades en intersección, cuestionando las nociones de género o identidad sexual como única base para la acción política.

Una vez aproximadxs a las políticas, acciones, estrategias de resistencia que llevan a cabo Ixs sujetxs o multitudes queer, considero necesario centrarnos en analizar cómo estas prácticas subversivas "aterrizan" en nuestro contexto, para así comprender la influencia que posteriormente tendrán en el seno de los movimientos feministas y de liberación sexual.

\subsection{Recepción de las teorías queer en el Estado español: tejiendo genealogías transfeministas}

"Ni lo queer nació en la universidad, ni nunca entrará en sus aulas de forma pacífica."

(Paco Vidarte, 2005, p. 77)

Durante la década de los noventa, el feminismo del estado se ve influenciado por los postulados de las teorías y prácticas queer. Los primeros grupos que empiezan a utilizar este término son La Radical Gai (LRG) y las LSD (Lesbianas sin duda) ${ }^{66}$. Será en el número 3 de la revista De un plumazo del grupo LRG cuando por primera vez el término queer aparezca en nuestro territorio (Solá, 2012) y también en el fanzine Non Grata de las LSD. De esta forma, teóricxs como Butler, De Lauretis, Wittig o Sedgwick serán traducidxs al castellano por estos colectivos. Son múltiples las temáticas que comienzan a trabajar, así como las alianzas que tejen entre los mismos. La identidad comienza a ser cuestionada por dichos grupos de

\footnotetext{
${ }^{66}$ LRG surge en 1991 como una escisión del COGAM y LSD en 1993 (Trujillo, 2005; Gil, 2011; Solá, 2012). Se inspiran en los colectivos queer de Norteamérica como Act up y Queer Nation y en sus revistas y fanzines comienzan a traducir textos de teóricxs queer así como a difundir este tipo de prácticas en nuestro contexto.
} 
activistas. La desnaturalización de la identidad de género y sexual será la base de las acciones políticas de los grupos queer. Gracia Trujillo afirma que:

Los grupos queer españoles van a cuestionar las representaciones, los espacios y los discursos normativos sobre las minorías sexuales, haciendo hincapié en la necesidad política de nombrarse, "contarse» y representarse a ellos y a ellas mismas. Frente al lenguaje normativo, utilizan la autodenominación que se adelanta al insulto. (...) Frente a las representaciones, de, por un lado, la cultura dominante cargada de puritanismo, prejuicios o «tolerancia» hacia las minorías sexuales, y, por otro, de un movimiento de gays y lesbianas que busca la integración social y la obtención de derechos - y que presenta, en general, una imagen normalizadora, integradora, pulcra, asexuada, homogeneizadora de la diversidad sexual- los grupos queer sacan a la palestra la multiplicidad de prácticas y cuerpos que reclaman su espacio y cuestionan la heterosexualidad como norma obligatoria. (2005, pp. 33-34)

Es decir, los nuevos colectivos queer del contexto español comparten con los primeros grupos queer nacidos en Norte América muchas características. Las cuestiones referentes al sida constituyen un pilar fundamental sobre el que trabajar de una manera diferente a los colectivos más oficialistas, "en gran parte surge como respuesta radical y llena de rabia a la crisis" (Trujillo, 2005, p. 35) y posibilita diferentes alianzas entre los colectivos más radicalizados, no desde identidades fijas, sino más bien desde afinidades, objetivos y proyectos políticos comunes.

Durante esta década, el feminismo también estaba siendo penetrado por los diferentes cuestionamientos que durante la década de los ochenta feministas autónomas, radicales, lesbianas, grupos de transexuales y trabajadorxs sexuales estaban desarrollando sobre la autonomía, la politización de la sexualidad o del cuerpo ${ }^{67}$. La década de los noventa también vio nacer a grupos como Rosa Que Te Quiero Rosa, muy activxs en la lucha contra el sida y en el fomento de una cultura de sexo seguro o La Casa Okupada de Mujeres La Eskalera Karakola quienes trabajan en las diversas intersecciones de opresiones y privilegios que nos constituyen: sexualidad, género, condición de migrante, condición de precaria, trabajo doméstico, etc.

\footnotetext{
${ }^{67}$ Para un análisis exhaustivo de las genealogías feministas del Estado español y las diversas temáticas sobre la autonomía, la independencia, la politización de la sexualidad, el trabajo sexual o la pornografía véase Gil (2011).
} 
Todas estas cuestiones y cambios a la hora de entender el género, el sexo, la sexualidad, los cuerpos o las formas de resistencia se van a consolidar en la primera década del siglo XXI a partir de diferentes colectivos como GtQ, Medeak, Guerrilla Travolaka, Maribolheras Precarias, La Acera del Frente, Transblock, Lilas, Post-Op, Girslwholikeporno, Ningún Lugar, Ex Dones, Panteras Rosas o La Asamblea Stonewall:

Colectivos feministas que, por un lado, ponen en cuestión que el sujeto político del feminismo sean solo "las mujeres", entendidas como una realidad biológica predefinida. Mientras que por otro, desarrollan una serie de discursos y de prácticas políticas dirigidas a la transformación social del sistema de género sin la necesidad de establecerse sobre la base de la determinación de una identidad cerrada. (Solá, 2012, p. 264)

Los diversos cuestionamientos, replanteamientos, críticas, reformulaciones que estamos tratando hacen que el movimiento feminista en el estado ya no sea uno, sino que sea diverso, múltiple, disperso, fragmentado. Lejos de tristezas, esto se ve por muchos sectores como oportunidades para la creación y expansión de estas nuevas formas de acción y lucha política. Silvia L. Gil señala las mutaciones que sufre el movimiento feminista, las cuales se constituyen como la base de lo que ella teorizará como Nuevos feminismos ${ }^{68}$.

Los Nuevos Feminismos no suponen una ruptura total con el movimiento sino que posibilitan las diversas transformaciones tanto en las temáticas como en las formas de organización. La multiplicidad, la diversidad, la dispersión serán señas características de las nuevas prácticas feministas que se empiezan a desarrollar en el estado. Desde otros lugares teóricos estas transformaciones se han conceptualizado como feminismos queer, feminismos postidentitarios, postfeminismos o transfeminismos. Más que centrarnos en discutir sobre el nombre o la etiqueta acerca de qué es o puede ser cada cosa, desde mi perspectiva lo

\footnotetext{
${ }^{68}$ Gil afirma que "aparecen, efectivamente, otras temáticas: la construcción de la identidad de género a través del movimiento transexual (desde 1987 con AET-Transexualia); la pornografía y la sexualidad, debatidas desde los colectivos de feministas lesbianas en los años ochenta; los derechos de las trabajadoras del sexo (con la fundación de Hetaira en 1995); las reflexiones sobre la identidad de mano de los primeros grupos queer (LSD y la Rádical Gai); el activismo lesbiano, la crítica a la institucionalización del movimiento gay y lésbico y las luchas contra el sida; el problema del cuerpo y la salud ambiental; la cuestión de la autonomía; el movimiento de resistencia global y las nuevas formas de expresión política; la construcción de la ciudadanía en las ciudades globales; las luchas y resistencias cotidianas de las mujeres migrantes y sin papeles organizadas a través de redes diversas; la crítica a la precarización de la existencia en el marco de la globalización, la crisis de los cuidados y los flujos migratorios; o la actualización de los discursos antimilitaristas a través de grupos como Mujeres de Negro." (2011, p. 38)
} 
interesante es rescatar las prácticas y discursos que se vienen desarrollando por estas colectividades y sujetxs políticos. A lo largo del texto yo utilizaré el término transfeminismo para referirme a todas estas mutaciones y formas de lucha que se dan dentro del movimiento feminista debido a mi propia vivencia, a mi experiencia como militante en dicho movimiento.

Sandra Fernández y Aitzole Araneta (2013) señalan dos procesos históricos en la constitución reciente del transfeminismo: un primer periodo que englobaría el surgimiento y la consolidación del movimiento trans prodespatologización (2006-2010) y un segundo período que se constituye con la consolidación del movimiento transfeminista (2010-2013) ${ }^{69}$.

Las autoras indican como hito fundamental de la historia reciente del movimiento las Jornadas Feministas Estatales de Granada (2009) donde diversxs activistas lanzan una serie de reflexiones al feminismo:

1) La interpelación al feminismo para que participase e hiciese suyas las demandas trans en torno a la despatologización. 2) La interpelación mutua en torno al discurso y las agendas: los silencios de los feminismos en torno a lo trans y los vacíos no pensados en el movimiento trans que comenzaban a cuestionar sus raíces feministas. 3) La reafirmación de un "transfeminismo" ante un tipo de feminismo tradicional basado en el pensamiento binario, condensada en la elaboración y la lectura del Manifiesto para la insurrección transfeminista. (Fernández y Araneta, 2013, pp. 52-53)

\section{TRANSFEMINISMOS: DESDE LO ESCRITO, ESCUCHADO, OBSERVADO Y EXPERIMENTADO. LA TEORÍA QUEER COMO BASE PARA LA COMPRENSIÓN}

"Todas las formas de feminismo que se han hecho después del feminismo convencional."

(Carmen, Manada Salvaje)

Es complicado ofrecer una definición clara sobre qué es el transfeminismo puesto que la propia esencia del movimiento es la pluralidad, la multiplicidad, la mutación, la diversidad de discursos, prácticas políticas y producciones culturales. Tampoco es la meta de este trabajo. Quizás sea más conveniente hablar de transfeminismos o enfatizar que no existe una definición monolítica sobre este movimiento. Partiendo de la premisa de que dichos conceptos son fluidos y permeables, de que se dejan penetrar por nuevas experiencias, trayectorias y vivencias parece necesario reflexionar sobre los contenidos que las palabras encarnan de

69 Para una comprensión en profundidad de dichos períodos, del movimiento trans prodespatologización, de las diversas temáticas, los retos, los desafíos, las rupturas y encuentros entre el movimiento Trans y el feminismo véase Fernández y Araneta (2013). 
manera situada. Para ello, haré uso de de las teorías e ideas que diversxs académicxs y activistas han desarrollado, así como de las interpretaciones que mis compañerxs realizan sobre los mismos; haré uso de cómo viven y experimentan ellxs (y yo) estos conceptos con los que nos enunciamos para acercarnos a una realidad compleja como es la transfeminista.

Como hemos visto en el apartado anterior, el transfeminismo surge de la proliferación de diferentes micro grupos de lesbianas, de feministas radicales, de feministas autónomas, de colectivos trans, de sujetos homosexuales no normativos y trabajadorxs sexuales en el contexto del Estado español. Estos grupos comienzan a desarrollar alianzas y a articularse tras la redacción y publicación del Manifiesto para la Insurrección Transfeminista ${ }^{70}$ durante las Jornadas Feministas Estatales de Granada en 2009.

Los discursos de estos colectivos aparecen en dichas jornadas con diferentes críticas y desafíos a algunos postulados del feminismo dentro de los debates sobre la identidad. Varios de estos desafíos giran alrededor del sujeto político clásico del feminismo, sobre la necesidad de realizar una crítica radical a la heteronormatividad y sobre el interés por las cuestiones Trans, pero enfatizando sus genealogías feministas. Itziar Ziga indica que ella prefiere "formular el transfeminismo como una actualización más, aquí y ahora, de la radicalidad del feminismo. Una actualización efervescente, bulliciosa, prometedora, ilusionante, que está sucediendo y, por tanto, podemos presenciar y vivir" (2013, p. 83).

El transfeminismo no niega su influencia feminista, no es una superación del feminismo, sino que extiende las formas y los discursos del feminismo clásico desarrollando temáticas y perspectivas diferentes sobre las que organizarse.

\subsection{Relectura transfeminista de lo queer}

"Al principio, los primeros momentos fue un poco de rechazo con tanto término academicista. (...) Luego te das cuenta de que está dentro de ti."

(Marina, Manada Salvaje)

"Cuando hablas de teorías queer nadie ve que detrás de queer hay un insulto ¿no? O es muy difícil que lo vea aunque te diga que queer en inglés es marica, bollera, tal... es difícil, es difícil."

(Kris, La Fábrika Crítica)

El transfeminismo realiza una lectura y una contextualización de las teorías y prácticas queer en el Estado español, y de esta manera, desarrolla una crítica radical al sistema binario sexo/género y a la estabilidad de las categorías sociales. En este sentido, Miriam Solá indica

\footnotetext{
${ }^{70}$ El Manifiesto para la Insurrección Transfeminista puede verse en el Anexo № 4.
} 
que "un conjunto de microgrupos han reclamado esta palabra que suena mejor en castellano que el término queer. Algo más tangible, más contextualizado, más local, cargado de potencia y de frescura, y que parece contener una importante fuerza movilizadora" (2013, p. 20).

El movimiento transfeminista asume las diferencias con los contextos donde dichas políticas y teorías han emergido. Nunca es fácil que el contenido de cualquier "traducción" consiga su instauración en otros contextos de manera plena, sin fisuras, dificultades o debilidades. Y eso ocurre con el concepto queer. Aun reconociendo lo positivo que el desarrollo de estas prácticas y teorías han aportado a diferentes personas y a diferentes luchas políticas, no son pocxs Ixs activistas que señalan diversas críticas a lo queer debido principalmente a su origen anglosajón, lo que hace que este concepto pierda parte de su potencial político, su historia, su memoria, su contenido:

Si tenemos en cuenta que la eficacia política del término "queer" proviene precisamente de ser la reapropiación de una injuria y de su uso disidente frente al lenguaje dominante habrá que aceptar que ese desplazamiento no se opera cuando la palabra "queer", desprovista de memoria histórica en castellano, català o valencià, se introduce en estas lenguas. Escapamos entonces al brutal movimiento de descontextualización, pero nos privamos también de la fuerza política de ese gesto. (Preciado, 2009, p. 17) ${ }^{71}$

Es imposible negar la influencia de lo queer en el movimiento, pero para muchxs activistas el concepto transfeminismo recoge mejor el contenido de las prácticas políticas y discursos que desarrollamos en nuestro contexto situado.

\subsection{Sexo y género como procesos performativos: nuestra "madre" Butler}

"En el taller que hicimos de Drag King/Queen/Queer trabajamos el género mucho como identidad desde la performatividad corporal, desde la modificación corporal, viendo un poquito, bueno, a través de algunas dinámicas cómo se construye y materializa esto del género."

(Lola, La Fábrika Crítica)

Piedra angular de nuestras prácticas y discursos transfeministas es la teoría desarrollada por Butler sobre la performatividad del género. Muchas de nuestras políticas y prácticas giran en torno a la concepción butleriana sobre el género y el sexo.

\footnotetext{
${ }^{71}$ Este texto aparece en el número 1 de la revista digital Parole de Queer. Puede consultarse en https://www.scribd.com/fullscreen/79992238?access key=key-2164jancgcgodxmcd3jir
} 
Siguiendo la teoría de los actos del habla (speech act) del filósofo Austin ${ }^{72}$ y varios postulados incorporados por Derrida ${ }^{73}$, Butler (1990) asegura que el género se produce de una manera performativa. La teoría de los del habla, entre otras cosas, señala que una característica fundamental del lenguaje es producir un efecto; no sólo el lenguaje describe, sino que tiene la capacidad de crear. Los enunciados performativos del lenguaje desarrollados por Austin se definen por la facultad de la acción más que de la descripción. El lenguaje no es simplemente descriptivo, sino que crea aquello que pretende describir. Lo que es necesario en ese proceso performativo es la iteración, la cita, la repetición. Así la importancia que dichxs autorxs le conceden al lenguaje reside en su capacidad realizadora. Butler asume esta lógica para descifrar el proceso en el que los géneros son producidos.

Butler (2007) [1990] afirma que el género se produce por la repetición de gestos, movimientos, discursos y prácticas, aunque el individuo lo experimente de una manera natural, como efectos ontológicos. Esto se debe precisamente al proceso constante de cita y repetición. Dentro de la matriz heterosexual de inteligibilidad, los efectos ontológicos de la identidad sexual y de género son producidos por un proceso performativo de imitación y repetición. Butler (2004) señala que a través de este proceso performativo de imitación y repetición, la heterosexualidad obligatoria se constituye en sí misma como lo normal, como lo auténtico, como lo verdadero. Pero la heterosexualidad, como las otras sexualidades, es producida de manera performativa. Los efectos naturalizados de la heterosexualidad se deben a que "la imitación es la que produce la noción misma del original como efecto y consecuencia de la propia imitación" (2004, p. 127) ${ }^{74}$. Ella argumenta que el original necesita la copia para constituirse en sí misma como original. Esto significa, que no hay original a priori de la copia sino que la heterosexualidad obligatoria necesita establecer a las otras sexualidades como la copia, como derivaciones, con el objetivo de establecerse como la original. De esta forma, Butler indica que esto es un efecto homófobo de la matriz heterosexual y argumenta que ambas categorías (original y copia) son mutuamente constitutivas; el original necesita la copia para existir, así, la heterosexualidad necesita la homosexualidad para emerger en un proceso de diferenciación y exclusión.

Asumiendo estos postulados, Butler rompe con la idea de que el género es la extensión cultural del sexo biológico y señala que es una práctica discursiva que se configura a través de la noción de heterosexualidad. La matriz heterosexual requiere consistencia entre el sexo, el

\footnotetext{
${ }^{72}$ Para una comprensión más profunda de dicha teoría véase Austin (1962).

${ }^{73}$ Para más información véase Derrida (1982).

${ }^{74}$ Traducción propia.
} 
género, el deseo y la práctica sexual, pero ella cuestiona esta afirmación afirmando que "la coherencia y la continuidad de la persona no son rasgos lógicos o analíticos de la calidad de persona sino, más bien, normas de inteligibilidad socialmente instauradas y mantenidas" (2007, p.71).

Este cuestionamiento lo fundamenta en la aparición cultural y proliferación de "seres con género incoherente o discontinuo que aparentemente son personas pero que no se corresponden con las normas de género culturalmente inteligibles mediante las cuales se definen las personas" (Ibíd., p.72). Así, demuestra los límites y las ansias de control de la matriz de inteligibilidad abriendo las posibilidades para la extensión de las fronteras de la misma.

Años más tarde, Butler se interesa por la materialidad del cuerpo y pretende explicar cómo el sexo es encarnado a través del proceso de reiteración de normas señalando que "las normas reguladoras del sexo trabajan de una manera performativa para constituir la materialidad de los cuerpos y, más específicamente, para materializar el cuerpo sexuado, para materializar la diferencia sexual al servicio de la consolidación del imperativo heterosexual" $(1993, \text { p. } 2)^{75}$. Así, expone como el sexo es producido en un proceso de materialización en el cuerpo dentro de la matriz de inteligibilidad haciendo posible la emergencia del sujeto.

Incorporando esta perspectiva sobre cómo el sexo, el género y el cuerpo se producen de manera performativa, el transfeminismo desarrolla diferentes estrategias de resistencia y de subversión de los parámetros de la norma heterosexual y de las categorías binarias de sexo/género como veremos más adelante cuando profundicemos con las experiencias del postporno o del pornoterrorismo.

\section{3 ¡Bollera, precaria y revolucionaria!: Wittig y la crítica tranasfeminista a la heteronormatividad}

"El tema de la sexualidad como régimen político heterosexual y coitocentrista lo curramos desde los discursos médicos, psiquiátricos, desde La historia de la sexualidad como dispositivo de poder."

(Lola, La Fábrika Crítica)

Siguiendo a autoras como Monique Wittig o Adrienne Rich, desde el transfeminismo entendemos la heterosexualidad como un régimen político y económico. Sus teorizaciones nos dan pie a conceptualizar a dicho régimen como el régimen de la heteronormatividad.

Rich problematiza la heterosexualidad obligatoria señalando que "la heterosexualidad, como la maternidad, necesita ser reconocida y estudiada como una institución política" (1980, p.

\footnotetext{
${ }^{75}$ Traducción propia
} 
$182)^{76}$. De esta manera, se asume que la heterosexualidad no es simplemente una práctica sexual sino que es un régimen que se apoya en diferentes instituciones, discursos y mecanismos para imponer una sexualidad obligatoria. Para la autora, la heterosexualidad obligatoria es el pilar fundamental sobre el que se sustenta la dominación masculina sobre las mujeres, es la base para el poder masculino. Ella se centra en analizar los diversos mecanismos con los que la heterosexualidad obligatoria oprime a las mujeres y concretamente a las lesbianas dificultando su existencia.

Desde un punto de vista materialista y en términos de conflicto de lucha de clases (hombres vs mujeres) Wittig entiende la heterosexualidad como un régimen político y económico que oprime a las mujeres a través de diferentes mecanismos. La autora nos deja una herencia de afirmaciones iluminadas como "no hay sexo. Hay pero un sexo oprimido y un sexo que oprime. Es esta opresión la que crea el sexo y no al contrario" (Wittig, 1992, p. 2) ${ }^{77}$. Esta conceptualización es tan potente que nos lleva a vislumbrar cómo no es el sexo el que precede al género, sino que es la opresión la que crea el sexo. Al igual que las ideas de Butler, estas premisas desafían años de historia de dominación que se basaban en la concepción binaria del mundo de los sexos y en la distinción tan radical entre el sexo como lo natural y el género como lo cultural.

En la misma línea, el pensamiento del feminismo materialista francés de Christine Delphy continua desafiando la idea de que el sexo precede al género cuando señala "la jerarquía como elemento constitutivo del género" $(1996, \text { p. } 35)^{78}$. Es decir, es la opresión, es la jerarquía, es la estructura la que configura los géneros, y no al revés. Como precisamente es la relación entre la mujer y el hombre en la estructura heterosexual lo que constituye a ambxs, Wittig no duda en afirmar que "las lesbianas no son mujeres" (1992, p. 32) puesto que se escapan de esta relación y además apuesta por ellas (la sociedad lesbiana) para destruir la noción del mito de la mujer como natural.

Interiorizando estos supuestos, no estamos demonizando las prácticas heterosexuales (iqué nadie se asuste!) sino que vamos más allá y realizamos un cuestionamiento sobre cómo la heterosexualidad es institucionalizada y cómo es esta estructura la que produce géneros, opresiones y dominación. Esto nos conduce a desnaturalizar la sexualidad y a politizarla.

\footnotetext{
${ }^{76}$ Traducción propia.

77 Traducción propia.

${ }^{78}$ Traducción propia.
} 


\subsection{Bebemos de los fluidos de Foucault y Preciado: la politización transfeminista de la sexualidad y el cuerpo}

"Para mí también lo que me trae el transfeminismo es que le da a la sexualidad una centralidad."

(Kris, La Fábrika Crítica)

Desde nuestras posiciones transfeministas otorgamos una centralidad a la sexualidad en nuestras prácticas, discursos, experiencias, críticas y estrategias de resistencia. Además de nuestro cuerpo, para ello, nos servimos de las teorías de Foucault y Preciado, entre otrxs.

Si Foucault afirma que a partir de las transformaciones producidas en el siglo XVIII se pasa de un "régimen soberano" de poder a una "sociedad disciplinaria", Preciado (2008) entiende que Foucault no toma en cuenta las transformaciones producidas tras la Segunda Guerra Mundial que nos llevarían a poder hablar de un "régimen farmacopornográfico" de poder y control de los cuerpos.

A partir de los postulados de Foucault, Preciado describe el Biopoder como "una nueva forma de poder productor, difuso y tentacular que desborda así el dominio de lo jurídico, del ámbito punitivo, para volverse una fuerza que penetra y constituye el cuerpo del individuo moderno" (2008, p. 57), el cual se apoya en nuevas arquitecturas disciplinarias como son las prisiones, los hospitales o las escuelas basadas en la estructura del Panóptico de Bentham ${ }^{79}$, además de nuevos textos científicos, estadísticas, recomendaciones de expertos, entre otras cosas, donde el sexo y la sexualidad poseen una centralidad fundamental (Preciado, 2008). Este régimen moderno ya no se caracteriza por las técnicas de dar la muerte, sino que su objetivo es la normalización, la producción y el control del sujeto. Preciado, tras tomar ideas de Foucault, Butler y Wittig, entiende la Sexopolítica como "una de las formas dominantes de esa acción biopolítica que emergen con el capitalismo disciplinario" (2008, p. 58) donde el "sexo entra a formar parte de los cálculos del poder, de modo que el discurso sobre la masculinidad y la feminidad y las técnicas de normalización de las identidades sexuales se transforman en agentes de control y modelización de la vida" (2008, p. 58).

De esta manera, a partir del siglo XIX dos instituciones, la ciencia (con la medicina a la cabeza) y el derecho, acaparan el poder y determinan lo normal y lo perverso, lo válido y la desviación configurando así la diferencia sexual como verdad anatómica, sentando las bases de la patologización de aquellas sexualidades que por alguna razón u otra no siguen la norma heterosexual a través de una serie de dispositivos sexopolíticos disciplinarios. Preciado señala

\footnotetext{
${ }^{79}$ Una descripción más detallada puede verse en Foucault (2010, p. 203).
} 
que en estos momentos "nos encontramos frente a sistemas duros y extremos de producción de la subjetividad" $(2008$, p.63) a través de los cuales se produce una naturalización del sexo y la sexualidad.

Pero tras la II Guerra Mundial, Preciado advierte de nuevas transformaciones en los sistemas económicos, políticos, simbólicos de creación de subjetividades (que Foucault pasa por alto) que nos llevarían a un tercer sistema de saber-poder a partir de nuevas tecnologías del control de los cuerpos y las subjetividades. Este tercer régimen lo denomina "Farmacopornográfico" y se configura a través de "nuevas tecnologías del cuerpo (biotecnología, cirugía, endocrinología, etc.) y de la representación (fotografía, cine, televisión, cibernética, etc.) que infiltran y penetran la vida cotidiana como nunca lo habían hecho antes" (Preciado, 2008, p.66). Así, el poder ya no vigila y controla desde fuera, desde el exterior, sino que lo hace desde dentro del mismo cuerpo confundiéndose con él. Se crea una nueva articulación política del sexo, y del cuerpo a partir de estas nuevas tecnologías.

Tomando las tesis de Butler y De Lauretis ${ }^{80}$ y queriendo incluir "el conjunto de técnicas fotográficas, biotecnológicas, quirúrgicas, farmacológicas, cinematográficas o cibernéticas que constituyen performativamente la materialidad de los sexos" (Preciado, 2008, p. 86), Preciado apuesta por el uso de un nuevo concepto, Tecnogénero ${ }^{81}$. Así, no existe una certeza real de ser hombre o mujer. Los cuerpos se construyen a través de un conjunto de tecnologías cargadas de símbolos, de significados de control y vigilancia, que se somatizan de tal manera que el individuo se entiende a sí mismo como algo natural, como algo trascendental. El género no es sólo performativo, sino que es prostético puesto que se materializa en el cuerpo (Preciado,

\footnotetext{
${ }^{80}$ Teresa de Lauretis, quien habla por primera vez sobre teorías queer, desarrolla el concepto de "tecnología de género" señalando que "podríamos así decir que el género, como la sexualidad, no es una propiedad de los cuerpos o algo que existe originariamente en los seres humanos, sino que es "el conjunto de los efectos producidos en cuerpos, comportamientos y relaciones sociales" como dice Foucault, debido al despliegue de "una compleja tecnología política". Pero debe decirse antes que nada, y de ahí el título de este trabajo, que pensar el género como el producto y el proceso de una serie de tecnologías sociales, de aparatos tecno-sociales o bio-médicos, significa haber superado ya a Foucault, pues su concepción crítica de la tecnología del sexo olvida la solicitación diversificada a la que esta somete a los sujetos/cuerpos masculinos y femeninos". (De Lauretis, 2000, p. 35). En el mismo texto, De Lauretis muestra los límites de la diferencia sexual y afirma que "la construcción del género es al mismo tiempo el producto y el proceso de su representación" (2000, p. 36). Estos postulados sirven de base para el desarrollo de las teorías queer y de diferentes experiencias de resistencia política.

${ }^{81}$ Beatriz Preciado (2008) diferencia entre bio-mujer/bio-hombre y trans-mujer/trans-hombre (o tecnomujer/tecnohombre), para diferenciar a aquellos sujetos que se identifican con el sexo asignado al nacer y a aquellos que no se sienten cómodos y pretenden modificarlo a través de procedimientos técnicos, prostéticos, performativos y/o legales.
} 
2002). Pero más allá de estas tecnologías de constitución de los cuerpos no podemos decir que existe un hombre o una mujer. Estas categorías son ficciones políticas vivas ${ }^{82}$.

La heterosexualidad concebida como tal es un invento médico burgués del siglo XIX que tiene el objetivo de homogeneizar, normalizar a la sociedad posibilitando de esta manera un control más fácil ${ }^{83}$. Preciado (2008) encuentra en la invención de las hormonas sexuales nuevas posibilidades de configuración de los géneros, nuevas formas de incoherencia entre el sexo asignado en el momento del nacimiento, el género y las prácticas sexuales:

Los biocódigos de producción de subjetividad (tanto performativos como farmacológicos, del Viagra a la testosterona, pasando por la estética gay o las prácticas sexuales con órganos sintéticos) circulan en el mercado farmacopornográfico sin que sea posible fijar completamente los procesos de producción de subjetividad que estos desencadenan. (Preciado, 2008, p.97)

Para Preciado, la reapropiación de estas tecnologías de construcción de los cuerpos posibilita la base para las estrategias de resistencia, ofreciendo impensables configuraciones de subjetividades. Es decir, el poder no sólo nos configura, sino que existen posibilidades de resistencia a partir de la reapropición de dichas tecnologías de control y producción que cuestionen la diferencia sexual y el sistema binario de género. Un ejemplo de ello sería el cuerpo cyborg $^{84}$, el cual sirve de base para varias experiencias de resistencia transfeminista ${ }^{85}$.

\subsection{Inclusión de las cuestiones Trans}

"Pues de inclusividad de otras voces, de otros cuerpos, otras sexualidades... eso es para mí el transfeminismo. (...) Es la articulación de muchas luchas."

(Lola, La Fábrika Crítica)
82 Véase la conferencia de Preciado
en
Hay
Festival,
Cartagena
2014:
https://www.youtube.com/watch?v=R4GnRZ7 -w4
${ }^{83}$ Para un análisis más exhaustivo del origen de la heterosexualidad véase Guasch (2000).
${ }^{84}$ Desde un lugar irónico Haraway desarrolla la metáfora del cyborg con el objetivo de rechazar premisas esencialistas, los dualismos y el pensamiento binario que rige occidente. Entiende el cyborg como el espacio para la resistencia y la subversión. La autora describe el cyborg como una criatura postgenérica, "un organismo cibernético, un híbrido de máquina y organismo, una criatura de realidad social y también de ficción. La realidad social son nuestras relaciones sociales vividas, nuestra construcción política más importante, un mundo cambiante de ficción” (1995, p. 253). (...) “El cyborg es materia de ficción y experiencia viva que cambia lo que importa como experiencia de las mujeres a finales de este siglo. (...) las fronteras entre ciencia ficción y realidad social son una ilusión óptica" (2005, p. 253). (...) "El cyborg elude el paso de la unidad original, de identificación con la naturaleza en el sentido occidental. Se trata de una promesa ilegitima que puede conducir a la subversión de su teleología en forma de guerra de las galaxias" (1995, p. 255). Esta metáfora sirve para el desarrollo de diversas experiencias políticas de resistencia queer y transfeministas.
${ }^{85}$ Véase por ejemplo el trabajo realizado por el colectivo Quimera Rosa que se nutre de la filosofía del cyborg, del postporno y de los transfeminismos: http://quimerarosa.net/ 
"El simple hecho de ponerle la palabra Trans delante... se abre mucho más a la hora de acoger ese movimiento, o esa estrategia de lucha."

(Marina, Manada Salvaje)

El transfeminismo entiende que la lucha trans es una lucha feminista y encuentra al menos cuatro puntos afines para la convergencia y la generación de alianzas. El primero de ellos gira en torno al derecho de autodeterminación del propio cuerpo (Missé, 2009; Platero, 2011). Derechos como el aborto o la reivindicación de tratamientos gratuitos para las personas trans en el sistema de salud pública son apuestas con una clara base feminista, la cual pretende liberar al cuerpo del dominio de la ciencia, de la medicina, del estado o de la religión. El segundo de estos ejes sobre el que articular alianzas es la reclamación de la retirada del sexo/género de los documentos nacionales (Missé, 2009; Platero, 2011). El tercero tiene relación con las operaciones quirúrgicas que se les realiza a las personas intersexuales durante los primeros días de vida. (Missé, 2009; Platero, 2011). Estas operaciones muestran cómo el sexo se construye bajo los parámetros binarios hombre/mujer. Y el cuarto punto de encuentro se centra en la crítica a la patologización de diferentes subjetividades no normativas y en la reclamación de la retirada del transtorno de identidad de género de los manuales psicológicos y psiquiátricos mundiales (Missé, 2009; Platero, 2011).

Estas reivindicaciones constituyen una fuerte crítica a los diferentes sistemas de normalización y de opresión que constituyen los cuerpos; suponen un cuestionamiento al heteropatriarcado. El transfeminismo lucha contra estas instituciones de control repensando el estatus del cuerpo. Asumiendo las concepciones foucaultianas sobre el poder y sobre las técnicas que el mismo utiliza en la construcción del cuerpo, desafía la idea del cuerpo normal y el cuerpo anormal, el cuerpo sano y el cuerpo patologizado.

\subsection{Desarrollo de una perspectiva interseccional}

"Nuestra identidad está formada por muchas casillitas ¿no? Desde el transfeminismo yo creo que se agrupan esas casillitas."

(Elena, Manada Salvaje)

"Claro, creo que es necesario. Creo que es urgente y necesario que hagamos alianzas porque no se trata de que yo tenga una opresión diferente a la tuya, se trata de que todas están interconectadas."

(Kris, La Fábrika Crítica)

Los discursos y prácticas del transfeminismo tienen un marcado carácter interseccional ${ }^{86}$. La perspectiva interseccional no sólo se centra en la opresión de género, sino que asume la

\footnotetext{
${ }^{86}$ El concepto de interseccionalidad fue introducido por Kimberlé W. Crenshaw en la teoría feminista con el objetivo de visibilizar las opresiones específicas que sufrían las mujeres negras. Para profundizar
} 
interacción de los diferentes sistemas de opresión y normalización como la sexualidad, la clase, la raza, la diversidad funcional, entre otras, en la construcción de exclusiones, discriminaciones, reconocimiento, redistribución, violencias o privilegios que cruzan las identidades (Lykke, 2011).

De esta forma, el tranfeminismo no se enuncia desde el sujeto político feminista clásico (mujeres) sino que se articula a partir de un(xs) sujetx(s) múltiple, diverso, complejo. Si el feminismo descentró el sujeto cartesiano privilegiado por excelencia de la Modernidad (Hall, 1992) visibilizando el androcentrismo que configura la realidad social, el transfeminismo opera de manera similar descentrando al sujeto feminista clásico y mostrando el carácter excluyente de la categoría fija y naturalizada mujer. El transfeminismo pretende desarrollar alianzas entre aquellxs que están en los márgenes del sistema configurándose como un movimiento inclusivo.

Platero señala que "todos vivimos atados por normas sociales heterosexualizantes, occidentalizantes, coitocéntricas y capitalistas, de efectos interseccionales" (2013, p. 220). El transfeminismo pretende desarrollar discursos y prácticas que presten atención a la interacción entre los diferentes sistemas de opresión y normalización, y a cómo estas interacciones producen vulnerabilidades diferenciales en los sujetos en relación con los contextos sociales ${ }^{87}$. Las alianzas políticas que el transfeminismo pretende generar se basan en un proyecto político común y en objetivos afines, pero no en identidades naturalizadas.

Dentro del debate sobre cómo desarrollar políticas sin identidades fijas, el transfeminismo enfatiza que es posible luchar contra los sistemas de opresión sin monolíticas y esencialistas subjetividades asumiendo que la construcción de los sujetos pueden ser producidas a partir de procesos jerárquicos y excluyentes (Medeak, 2013). Así, transgrede los límites de las políticas de identidad, pero apelando a ella cuando sea necesario, asumiendo el esencialismo estratégico desarrollado por la crítica postcolonial.

en los contenidos de la teoría de la interseccionalidad véase Crenshaw (1989), Brah y Phoenix (2004), Puar (2012).

${ }^{87}$ Un ejemplo de este enfoque interseccional es encarnado por el colectivo Post-Op ${ }^{87}$, quienes han participado en el proyecto Yes we fuck que trabaja las conexiones políticas entre la diversidad funcional y las sexualidades no normativas. El trabajo de este grupo de artivistas transfeministas y postporno puede consultarse en http://postop-postporno.tumblr.com/. Información sobre el proyecto Yes We fuck puede consultarse en http://www.yeswefuck.org/. Otro ejemplo de ello, es el colectivo Migrantes Transgresores quienes desde sus diversidades sexuales y de género, su condición de migrantes y precarixs trabajan dichas articulaciones. Más información sobre este colectivo puede consultarse en http://migrantestransgresorxs.blogspot.com.es/p/quienes-somos.html 


\subsection{Situando el Pornoterrorismo y el Postporno como políticas transfeministas}

"Es una perspectiva que viene a deconstruir el sistema binario de género, a deconstruir que no sólo hay hombres y mujeres. (...)Lo que me lleva a mí a deconstruir el sujeto feminista, es decir, el feminismo no es para las mujeres."

(Kris, La Fábrika Crítica)

El pornoterrorismo ${ }^{88}$ es una experiencia política y artística que desarrolla sus fines utilizando el cuerpo como el elemento más poderoso para la resistencia; es acción y estrategia. Sus objetivos están conectados con la desestabilización del sistema heteronormativo y con el cuestionamiento de cualquier régimen de control de nuestros cuerpos, deseos y existencias. Como acción, el pornoterrorismo es intrínsecamente performance ${ }^{89}$. En conexión con estas características, Diana J. Torres, la creadora del concepto Pornoterrorismo señala que:

Nuestras armas vienen integradas dentro de nuestros cuerpos, no necesitamos una industria que nos avale y nuestro sexo, nuestro deseo y nuestro amor-odio están ahí para ayudarnos a conseguir cambiar las cosas. Hay que darse cuenta del poder que pueden aportarnos nuestras entrepiernas y nuestros corazones liberados, quizás entonces podremos pasar a la acción. Podremos «tomar partido hasta mancharnos». (Torres, 2011, p. 123)

La performance pornoterrorista está inspirada en las políticas y teorías queer puesto que intentan cuestionar la autenticidad y la verdad de los géneros y la sexualidad a través de las acciones performativas. Lxs sujetxs que constituyen esta experiencia se conectan con lo queer

\footnotetext{
${ }^{88}$ Más información sobre esta experiencia puede consultarse en http://pornoterrorismo.com/

${ }^{89}$ Siguiendo el Manifiesto Pornoterrorista algunos de los elementos que esta experiencia utiliza son: poemas y palabras hablando sobre el terror, sobre el amor, el sexo, sobre los deseos prohibidos. Así constituyen una provocación y una subversión de la heteronormatividad. Otro de los elementos que ocupan gran importancia en la elaboración de estas performances es la descontextualización de imágenes sobre guerras, muertes o violencia con el objetivo de hacer llegar a la audiencia las tragedias del mundo, rompiendo los mecanismos con los que los medios de comunicación nos convierten en seres pasivos e insensibles sobre estas violencias. De esta manera, la estética gore y snuff son características de estas performances. Imágenes sobre géneros, sexualidades, pasiones prohibidas son piedras angulares de este arte político. A veces, la música y el ruido guían la performance cuando no hay palabras en la escena. Otras veces, la audiencia es partícipe de la performance, así, el pornoterrorismo rompe los límites entre Ixs performers y Ixs espectadores. El sexo en vivo es un elemento fundamental del pornoterrorismo: BDSM, fistings (anales o vaginales), squirting, masturbaciones, dildos, látigos, lubricantes, arneses, microcámaras. Sexo bizarro, sexo no normativo, sexo desgenitalizado muestran alternativas prácticas sexuales, cuerpos no normativos, deseos no normativos. Fluidos, semen, vómitos, lágrimas, sangre abundan en la performance pornoterrorista. Todos estos elementeos configuran el cuerpo pornoterrorista. El Manifiesto Pornoterrorista puede consultarse en http://pornoterrorismo.com/lee/manifiesto-pornoterrorista/
} 
al describirse como montruxs, perras, putxs, precarixs, transfeministas, desviadxs, terroristas ya que:

cualquier persona etiquetada por la sociedad como monstruosa, peligrosa o molesta puede ser llamada terrorista. Y si el tema del sexo o el género está por medio entonces hay motivos mayores, porque son conceptos que provocan temblores (cuando se salen de los límites establecidos) en la estructura del sistema con mayor facilidad que otros. (Torres, 2011, p. 53)

Encuentro en esta formulación conexiones con las hipótesis de Jasbir K. Puar y José Esteban Muñoz cuando teorizan sobre el queer terrorist ${ }^{90}$ y el drag terrorist. Puar muestra la tradicional conexión entre queer y terror. Estos cuerpos son considerados perversos, traidores de la nación, monstruos, etc. porque "lo queer (lo raro, lo extraño) está siempre instalado en el proyecto de nombrar al terrorista; el terrorista no aparece como tal sin la entrada simultánea de la perversión, la desviación, deformidad" (Puar, 2005, p. 127) ${ }^{91}$. Así, lo queer es un elemento constitutivo de la idea de terrorista.

De manera similar, José Esteban Muñoz (1997) describe a la performer Vaginal Davis ${ }^{92}$ como terrorist drag ya que ella transgrede el sexo, el género y la raza performando los miedos nacionales sobre dichas categorías ${ }^{93}$. Acorde con estas ideas, las performances pornoterroristas también están inspiradas en la filosofía del postporno ${ }^{94}$ y en las teoría de la performatividad de Butler puesto que una de las metas de estas experiencias es el cuestionamiento de las representaciones tradiciones de los cuerpos, los géneros y las

\footnotetext{
${ }^{90}$ A través del concepto de queer terrorist, Puar pretende extender el significado de queernes para entender diferentes corporalidades no normativas y rechazar la idea de que lo queer es una identidad fija. Explora varios ejemplos y señala que dichas corporalidades son terroristas porque el cuerpo queer cuestiona la noción de nación, raza, género y sexualidad. La performance pornoterrorista trabaja en el mismo sentido cuestionando el género, las sexualidades normativas, las corporalidades normativas y las prácticas sexuales normativas.

${ }^{91}$ Traducción propia.

${ }^{92}$ Información sobre esta performer puede consultarse en http://www.vaginaldavis.com/

${ }^{93}$ Tanto Vaginal Davis, como la performance pornoterrorista desestabilizan las ideas de rigidez sobre el género, la sexualidad o los cuerpos. Ambos tipos de performances constituyen un acto terrorista puesto que cuestionan la coherencia y la continuidad de las identidades; además, utilizan el deseo para desarrollar sus objetivos políticos. La desidentificación del género como estrategia es usual en dichas experiencias. Ambos tipos de performance están cuestionando los discursos y la ideología dominante y en numerosas ocasiones utilizan el humor y la parodia como una estrategia de crítica cultural.

${ }^{94}$ El postporno fue popularizado por la activista pro-sex y artista Annie Sprinkle durante la década de los noventa. Sus performances deconstruyen la heterosexualidad naturalizada y las representaciones de la misma en la pornografía mainstream. Annie Sprinkle enunció la frase "si no te gusta el porno que hay, hazlo tú misma", posibilitando el surgimiento de la cultura Do it yourself (DIY), la cual inspira a numerosas estrategias de resistencia postpornográficas y transfeministas.
} 
sexualidades en la pornografía mainstream asumiendo el poder de la performatividad para hacer visibles y producir otras realidades.

El postporno pretende subvertir las normas regulatorias de la matriz de inteligibilidad desestabilizando las nociones normativas de género, sexualidad y corporalidad mostrando diferentes sujetxs que no se ajustan a estos cánones y cuestionando el origen biológico de la diferencia sexual. La activista transfeminista Lucía Egaña indica que:

La performance, así como es llevada a cabo por AS (Annie Sprinkle), se pone al servicio de la creación de un espacio político, donde cuestiona los códigos del género, de la pornografía y del sexo. A través de sus performances cuestiona el estatuto del cuerpo dentro del imaginario pornográfico. (2009, p. 8)

Siguiendo las tesis de Teresa de Lauretis, la pornografía constituiría una potente tecnología que produce género. Por el contrario, la postpornografía podría constituir una anititecnología de género, puesto que pretende cuestionar los dualismos, visibilizar nuevas identidades y representar deseos y placeres alternativos y desviados de la norma ${ }^{95}$.

Alberto García describe el postporno como "aquellas producciones audiovisuales nacidas como crítica y cons-trucción de representaciones de sexualida-des no dominantes, en una etapa avanzada de movimientos homosexuales, feministas pro-sexo y queer" (2011, p. 362). García (2011) indica como fundamentales dos características del postporno: la apropiación y el empoderamiento.

El postporno se apropia del lenguaje de la pornografía mainstream con el objetivo de producir otras realidades y esto supone una estrategia de empoderamiento para quienes lo realizan. Así, empoderamiento y apropiación trabajan en la misma línea que la resignificación explicada por Butler (1997).

Lo que fue un estigma (queer) y pasó a convertirse en un lugar de resistencia, en el postporno ${ }^{96} \mathrm{y}$ en el pornoterrorismo ocurre de la misma manera. El estigma de perra, de puta, de marica, de bollera, de viciosx, de perversx, de inmoral, de desviadx, a través de un proceso

\footnotetext{
${ }^{95}$ En este sentido, María LLopis señala que el postporno es "la apropiación de un género, el de la representación explícita del sexo, que ha sido hasta ahora monopolizado por la industria. El postporno es una reflexión crítica sobre el discurso pornográfico. Como dice Tim Stüttgen, teórico alemán del postporno y performer, mientras que la pornografía convencional genera un tipo de placer o de goce conocido, el postporno crea una ruptura: rompe esa estructura convencional y nos obliga a reconstruir nuestro deseo bajo nuevos parámetros". (2010, p. 38)

${ }^{96}$ Una tesina sobre el postporno desarrollada desde Granada puede verse en Flores (2012).
} 
performativo puede ser resignificado, reapropiado y posibilita la base para el empoderamiento de dichxs sujetxs. Pero este proceso es sólo posible de manera colectiva. El poder de la manada de perras permite la apropiación, la resignificación y el empoderamiento de estxs montruxs.

\section{PENSANDO LO COMÚN EN EL CONTEXTO DEL CAPITALISMO GORE: LA SOSTENIBILIDAD DE LA VIDA Y LA VULNERABILIDAD DEL CUERPO}

"Lo peor que le puede pasar al capitalismo es la lucha Ecotransfeminista pues desestabiliza el heteropatriarcado y el consumo."

(Nota del diario de campo, 11 de mayo de 2015. "Conversaciones con Julito y Turbi")

Orozco y Lafuente afirman que "el sistema capitalista es heteropatriarcal en tanto se basa en una comprensión dicotómica y heteronormativa del mundo" (2013, p.99), es decir, se asienta en la lógica binaria cartesiana de la Modernidad y en la concepción de una heterosexualidad obligatoria entre los géneros y su complementariedad. Como se ha denunciado desde diversos posicionamientos esta comprensión dual y dicotómica de la realidad social produce diferentes tipos de jerarquías, explotaciones o violencias, otorgando privilegios diferenciales a sujetxs en función de las características que conforman sus identidades.

Siguiendo a Orozco y a Lafuente, "no podemos entender cómo funciona la economía si no atendemos a las relaciones de género porque, además del capitalismo, el heteropatriarcado también regula la organización de recursos y trabajos" (2013, p. 92). Ambos sistemas, capitalismo y heteropatriarcado, construyen dos esferas diferenciadas entre sí, la esfera productiva y la reproductiva y/o de cuidados cuyas fronteras son permeables y no se pueden entender la una sin la otra. Para un análisis exhaustivo de la relación entre ambas esferas de la vida económica y social algunas autoras como Mạ Ángeles Durán han planteado la metáfora del lceberg ${ }^{97}$ (Orozco, 2006).

Esta configuración se rige bajo los mandatos del sistema de sexo/género. De esta manera, la esfera productiva (monetizada) se relaciona con lo vinculado a la masculinidad, y la esfera reproductiva (no remunerada e invisibilizada) se asocia a lo femenino. Esto supone un reparto diferente de recursos, prestigio, poder y reconocimiento social privilegiando a aquellos sujetos que se posicionan en la esfera productiva del sistema económico. Además del género, son

\footnotetext{
${ }^{97}$ La metáfora del iceberg "permite recuperar algunas nociones claves hace tiempo señaladas por la crítica feminista a la división sexual del trabajo (...), así como plantear una nueva perspectiva que no sitúe a las esferas visible e invisible en el mismo plano de análisis y de relevancia social, sino que muestre cómo la segunda es la base de toda la estructura económica" (Orozco, 2006, p. 237).
} 
otros los ejes que intervienen en esta construcción de la estructura como la clase, la raza, la etnia, la sexualidad, la geografía o la diversidad sexual.

Sayak Valencia va más allá al describir ciertas dinámicas económicas actuales conceptualizando este fenómeno como capitalismo gore. ${ }^{98}$ La autora entiende a la violencia extrema como el eje transversal que configura el sistema económico, como la columna vertebral del capitalismo gore $e^{99}$ y concibe estas dinámicas "como herramienta de empoderamiento y de adquisición de capital" (2010, p. 90), generadoras de plusvalía que hacen de las mismas "una forma de vida, de trabajo, de socialización y de cultura" (2010, p. 93). La lógica sobre la que se sostiene el capitalismo es la lógica de la acumulación de capital, lo que supone otorgarle una centralidad a los mercados frente a la vida.

Esta lógica de acumulación "conlleva una amenaza constante sobre la vida, lo que hemos llamado el conflicto entre la acumulación de capital y la sostenibilidad de la vida" (Orozco \& Lafuente, 2013, p. 101). En este conflicto capital - vida, la economía feminista ha sacado a la luz diversas cuestiones que visibilizan dónde se sostiene la vida si no es en los mercados, quiénes son las personas encargadas de ello y quiénes son los sujetos privilegiados de este conflicto.

\subsection{La vulnerabilidad del cuerpo en el centro del debate}

"Preguntarse por el buen vivir es también preguntarse por la sexualidad y el deseo sexual."

(Amaia P. Orozco, 2014, p. 232)

Desde posicionamientos transfeministas planteamos estas cuestiones con una mirada especial. Sobre el objetivo central de la sostenibilidad de la vida se señala que debemos pensar esta vida no de una forma abstracta sino de una manera encarnada (Orozco \& Lafuente, 2013). Así, se entiende la vida encarnada como cuerpos vulnerables, interdependientes y ecodependientes señalando la necesidad de pensar las “desesidades hechas carne" (Orozco \& Lafuente, 2013, p. 98). Valencia (2010) señala la centralidad de la política corporal al indicar que:

\footnotetext{
${ }^{98}$ Valencia se refiere al capitalismo gore como el "derramamiento de sangre explícito e injustificado (como precio a pagar por los tercermundizados de todo el orbe, quienes se aferran a obedecer las lógicas del capitalismo, cada vez más exigentes), al altísimo porcentaje de vísceras y desmembramientos, frecuentemente mezclados con la economía del crimen, la división binaria del género y los usos predatorios de los cuerpos, todo esto por medio de la violencia más explícita como herramienta de necroempoderamiento." (2013, p. 109)

99 Asumiendo las premisas de los conocimientos situados de Haraway (1995), Valencia señala que no se puede asegurar "que la categoría de capitalismo gore sea válida e idéntica en todos los contextos. Sin embargo, esta forma de entender la violencia como herramienta de enriquecimiento se encuentra de forma creciente en distintos espacios geopolíticamente lejanos y está siendo globalizada" (2013, p. 110).
} 
La vigencia de la política corporal se basa en el hecho de que nuestros cuerpos son depositarios de todas las acciones, son relacionales y pueden ser entendidos como partes integrales, activas, de los acontecimientos, como vehículos y vínculos de socialización, enclaves últimos y primigenios que todos compartimos. (p. 196)

Desde estas perspectivas no esencialistas no se entienden los cuerpos como simples entes naturales, sino como construcciones sociales que pueden cuestionar la lógica dicotómica que jerarquiza y constriñe libertades, deseos, prácticas o formas de relacionarse con Ixs demás. Los cuerpos son entendidos como productos de discursos y prácticas sociales y a la vez productores y reproductores de discursos y prácticas (Spargo, 2004; Butler, 2011). Butler señala que "cada uno de nosotros se construye políticamente en virtud de la vulnerabilidad social de nuestros cuerpos -como lugar de deseo y de vulnerabilidad física, como lugar público de afirmación y de exposición - (Citado en Valencia, 2010, p. 196). En este sentido, Orozco y Lafuente afirman que "las dimensiones sexuales de la vida (en interrelación con el resto de dimensiones) deben estar en primer plano del debate" (2013, p. 98).

Al señalar la interdependencia, la ecodependencia y la vulnerabilidad de la vida en un sentido más holístico, y de la vida encarnada específicamente, debemos asumir la vulnerabilidad de nuestros cuerpos como lo indiscutible (Valencia, 2013). Esto implica reconocer la violencia que se ejerce por parte del sistema contra el cuerpo, lo que supone un proceso de vulnerabilización y de precarización de existencias. Valencia afirma que "la vulnerabilidad y la violencia obedece a cuestiones geopolíticas, pero esa distancia o cercanía geopolítica no nos exime de tomar responsabilidad por la vida física de los otros" (2010, p. 197).

Todas estas aportaciones nos llevan a reflexionar sobre cómo el género atraviesa y da existencia al actual sistema económico y social y cómo todo ello está muy vinculado a la producción de dicotomías, dualismos y posiciones binarias regidas por la lógica de la matriz imperante. Valencia (2010) sostiene que incluso más fuerte que la producción de petróleo o energías por parte del sistema, es la producción de subjetividades pero encuentra desde ahí una posible vía para la resistencia micropolítica. Plantea una desvirilización de la sociedad, pues afirma que estas dinámicas violentas están muy vinculadas a la producción de la masculinidad hegemónica ${ }^{100}$.

\footnotetext{
${ }^{100}$ Valencia afirma que "es necesario que las inundaciones y agenciamientos de los sujetos que buscan ofrecer una crítica y una resistencia ante el sistema dominante pasen por la conciencia del devenir mujer, devenir negr@, devenir indi@, devenir migrante, devenir precari@ en lugar de reificar su pertenencia a un único género o a un grupo social para demarcarse dentro de una lucha sectorial;
} 
Como podemos observar, estas violencias y opresiones nos afectan a todxs aunque de manera diferencial, como ya hemos señalado, debido a la intersección que configura nuestras subjetividades. Desde diferentes lugares teóricos y activistas se pretende rescatar, repensar, reflexionar sobre estas cuestiones comunes que nos afectan. Se pretende posicionar en el centro la reflexión sobre dichas problemáticas comunes y se apuesta por organizarnos políticamente desde estas premisas:

Lo común como punto de partida y lo común como punto de llegada; a dos niveles: una noción común sobre qué vida merece ser vivida y sobre cómo hacerla posible; y a dos bandas, elaborar propuestas inmediatas que den soluciones urgentes a la vez que permitan transformaciones radicales. (Orozco, 2014, p. 224)

En la misma línea, Silvia L. Gil nos invita a repensar aquellas cuestiones y problemáticas sociales en las que de alguna forma todxs nos vemos inmersas: precariedad (no sólo laboral, también existencial), mercantilización de todas las esferas de la vida, privatizaciones, movilidad, dificultad para tejer redes afectivas, de cuidados y de apoyo debido precisamente a las anteriores dinámicas del capitalismo heteropatriarcal:

El reto es construir lugares comunes, imaginarios y nombres que expresen situaciones compartidas, sin abandonar la complejidad, la singularidad y la multiplicidad existentes. (...) Se trata de escuchar y potenciar lo que hay en cada vida atomizada que consigue hacer resonar y vibrar lo común; se trata de desafiar la lógica del individualismo y de la separación dándole un nuevo sentido a nuestra experiencia; se trata de elaborar problemas conjuntamente. $(2011$, p. 314)

Seguiremos reflexionando sobre estas cuestiones en el siguiente apartado a partir de las reflexiones de dos experiencias transfeministas de la ciudad de Granada: Manada Salvaje y La Fábrika Crítica.

6. ACERCAMIENTO A DOS EXPERIENCIAS SITUADAS: MANADA SALVAJE Y LA FÁBRIKA CRÍTICA. MI CONSTRUCCIÓN DEL DISCURSO COLECTIVO DE LA MANADA

"A las quemadas en la hoguera, a las vivas y a las muertas..."

(Texto del aquelarre de Manada Salvaje)

debemos trabajar la resistencia como un proceso que se interrelaciona con otros procesos minoritarios". (2010, p. 180) 
Lo que a continuación presentaré será una especie de diálogo imaginado, al menos, a seis voces, cuerpos y pensamientos. La mía, la de tres integrantes del grupo de performances Manada Salvaje y las de dos compañeras de La Fábrika Crítica. Digo al menos seis, puesto que aunque lo que aquí está escrito emana de estas seis corporalidades, la materialización de los discursos en nuestros cuerpos recoge las cientos de reflexiones compartidas con muchxs compañerxs que a lo largo de este tiempo nos han construido. Por eso, como cualquier encarnación, es una encarnación de algo colectivo que se inscribe en el cuerpo que enuncia.

Ya hemos escuchado algunas de sus reflexiones, pero sus vivencias, trayectorias y experiencias se irán mostrando a continuación y serán las que me permitan cumplir mi pretensión, la cual ha sido elaborar dos discursos colectivos a partir de cinco entrevistas individuales. Siempre intentando respetar lo personal, lo subjetivo, lo emocional de cada una de ellas pero aspirando a llegar a lo colectivo, a lo político, a lo comunitario. Para mí ha sido fundamental hacer visibles aquellas posiciones emocionales individuales de cada unx de nosotrxs pero con el objetivo de construir un común.

He intentado acercarme a los discursos y prácticas políticas y artísticas de estos colectivos desde una posición situada como entiendo haber dejado claro a lo largo del texto. El objetivo, a la vez que el reto, ha sido el de mantener en la medida de lo posible sus palabras, sus discursos, sus gritos y aullidos ${ }^{101}$. De ahí, que gran parte de este escrito posea una perspectiva emic. Claro está que han sido mis manos las que lo han desarrollado, ha sido mi visión la que ha construido estos discursos colectivos y no está demás reconocer que también existen interpretaciones, análisis, observaciones, notas, apuntes y (de)construcciones personales.

Aprendizajes, desvelos, constataciones, sorpresas, desafíos, retos, alegrías, uniones, acercamientos, entendimientos, rupturas, desestabilizaciones, emociones, pensamientos, pasiones, incitaciones, recuerdos, recorren las líneas siguientes que pretenden aportar algunos granitos de arena más para comprender una realidad que se erige como combativa, subversiva, no complaciente ni pasiva, transgresora, cuestionadora y rebelde como es la realidad transfeminista granadina.

Que estas palabras sirvan de introducción de lo que a continuación se narra.

\footnotetext{
${ }^{101}$ Utilizo los términos palabras, discursos, gritos y aullidos para dar cuenta de la hibridez que compone este texto que se nutre de diversas experiencias e interacciones con mis compañerxs, perras de la manada, en manifestaciones, talleres, entrevistas, performances y fiestas.
} 


\subsection{De lo personal a lo político o al revés: buscando las rutas hacia la Manada Salvaje}

"Tenía la necesidad de salir a la calle y de romper..."

(Marina, MS)

Manada Salvaje, también conocidas como Perras Callejeras, es un colectivo formado por compañeras, amigas, amantes que surge en Granada en el año 2013 con el objetivo de aunar arte y política. Como cualquier fenómeno social, colectivo o grupo político está formado por diversas trayectorias, genealogías, estirpes, antecedentes que posibilitan el asentamiento de algo nuevo, algo diferente pero que se enraíza en su pasado, en sus historias. Para llegar a Manada Salvaje primero debemos prestar atención a un conjunto de personas diversas que formaron un grupo de debate donde reflexionaban y teorizaban sobre distintos aspectos de la realidad social atravesados por el sistema de género, cuestionándose privilegios, opresiones, inquietudes, identidades, sentimientos y emociones.

A algunas integrantes de este grupo les surgió la necesidad de salir a la calle, de sacar todo aquello que estaba en el interior, en el pensamiento y romper barreras en las mentes normativas de la ciudad. Nadie sabía que esa primera acción sería el germen de lo que posteriormente devendría en una manada, Manada Salvaje. El 8 de marzo de 2012 con motivo del día internacional de la mujer trabajadora, diversas compañeras de ese grupo de debate y reflexión decidieron actuar en la facultad de Medicina. La elección de este espacio no fue casual ya que en esos momentos la crítica principal de su performance iba dirigida al DSM IV $V^{102}$ y a las patologías acerca de las mujeres y de otras identidades de género no normativas que este manual recogía. Pasamontañas, desnudos, manchas de regla, frases escritas en los cuerpos y un texto del libro Pornoterrorismo engendrado por Diana J. Torres hicieron temblar los pilares del gran templo del saber científico.

Ese mismo día, tras la euforia por el éxito de este acto de rebeldía, decidieron repetirlo en la facultad de Ciencias Políticas y Sociología y en la cafetería de Trabajo Social con resultados similares. En tres horas cargadas de energías y ebullición tambalearon cimientos mentales de quienes les vieron. Algo estaba cambiando en la ciudad. Una "manada de perras" comienza a articularse para reapropiarse de espacios robados, de cuerpos usurpados, de saberes silenciados por el heteropatriarcado.

\footnotetext{
${ }^{102}$ El DSM es el Manual diagnóstico y estadístico de los trastornos mentales de la Asociación Americana de Psiquiatría. La edición actual es el DSM V, publicada en mayo de 2013. Históricamente este manual ha recibido numerosas críticas por parte de la comunidad LGTBIQ o por el movimiento feminista debido a su carácter patologizador de todo aquello que se aleja de la normatividad.
} 
Tras el parón estival que sufren los movimientos sociales y políticos en nuestro hábitat, la ciudad de Granada, algunas de aquellas que participaron en la primera acción habían dejado la ciudad el curso siguiente. Granada, ciudad de tránsito, de transición, de cambios y rotación, despide cada año a muchas personas para dar paso a otras nuevas cargadas de energías, motivaciones y ganas de experiencias; en el fondo personas ingenuas de la transformación personal, identitaria y subjetiva que conlleva el habitar este contexto. Nos ha pasado a todxs.

Las que permanecieron en la ciudad seguían con la necesidad de sacar todo aquello que llevaban dentro, de gritar, de aullar, de materializar los sentimientos que surgían de sus entrañas. Elena lo cuenta así:

"Manada, sí, surgió de redes afectivas, y de una necesidad de hacer acciones de cara a la gente, de sacar afuera lo que nosotras habíamos pensado el año anterior con un grupo de género que teníamos... donde nos cuestionábamos muchas cosas. Y era como materializar todos esos pensamientos y esos sentimientos que teníamos."

Algo que, en un primer momento, surgió de diferentes subjetividades, de diversos objetivos, de múltiples intereses. Algo que nace de la necesidad de expresar, de crear, de enunciar emociones y sentimientos, de materializar teorías y pensamientos ¿En qué se ha transformado?

"Eso fue el principio. Y ahora claro, ya Manada, no es sólo algo, algo formal, artístico, con ese objetivo personal, es como mi red de apoyo aquí en Granada. Entonces se ha transformado en algo super emocional, algo que partió un poco de... que partió de algo mucho más político ¿no? o... sí, desde algo que nacía un poco individual desde muchas, lo hemos construido en algo unitario de todas ¿no? (...) Es, sí, mi familia también." (Carmen, MS)

Al igual que me pasó a mí con mi propia manada de perras, les ha ocurrido a ellas. Entiendo que este tipo de militancia que parte tanto de lo personal, de los subjetivo, de lo emocional, de nuestras vivencias hace que a través de este proceso de lucha política mute en algo más, hace que se creen vínculos, lazos, redes afectivas, hace que se conforme una nueva familia, distinta a la familia de origen, una familia elegida con la que compartir alegrías, tristezas, llantos, sexo, amor, cuidados, luchas, música y fiesta.

\section{Hitos que nos conducen al (Trans)feminismo}

"Yo encontré en el feminismo las alas para echar a volar..."

(Elena, MS)

A lo largo de este período de investigación una de las cuestiones con las que me estoy acercando a mis compañerxs, algo que me agita y que no paro de preguntarme es ¿qué nos 
mueve a crear este tipo de manadas? ¿Qué ha pasado con nosotrxs a lo largo de nuestras vidas para construir estas jaurías? Vuelvo a suscribirme a la idea de que lo personal es político y a su vez teórico y esta consideración guía mis inquietudes, interrogantes y aproximaciones.

Elena, almeriense, quien describe su ciudad como árida para el desarrollo de los movimientos sociales señala dos aspectos diferentes de su vida que le conducen a la Manada. Por un lado, la participación en el 15M hizo revitalizar aquellas aspiraciones políticas y sociales que habían habitado sus pensamientos a lo largo de su vida. Esta pertenencia al movimiento que a tantas personas nos ha cambiado, nos ha penetrado, nos ha llevado a ser quienes somos, fue dibujando y conformando el contorno del cuerpo rebelde que habita.

No sabe y no quiere saber exactamente dónde situarse. La fluidez, el tránsito, las no etiquetas, el dejarse afectar y conformar por sus experiencias vitales van construyendo su identidad múltiple que va cambiando en cada contexto. Es su proceso vital:

"¿Quién soy? Yo creo que eso es la pregunta, o más bien la respuesta que yo llevo buscando a lo largo de mi vida, que es quién soy. Porque sé las cosas que me han ido construyendo, pero en realidad no llego a situarme en algo en concreto porque siempre voy cambiando, en realidad. $Y$ de hecho, es una cosa que ahora mismo yo estoy trabajando un montón, que es el no cerrarme a nada, y por eso también me gusta tanto el transfeminismo. (...) Ahora mismo, yo creo que Elena es sus emociones y sus capacidades."

Como veremos a continuación, la importancia que Elena le otorga a las emociones será una constante en las integrantes del grupo. Lo afectivo, lo emocional, el cuidado, la ternura son piedras angulares de los itinerarios biográficos que componen Manada Salvaje y que pretenden reivindicar a través de sus performances. Lo emocional, siempre vinculado a la naturaleza y a la feminidad, entendido históricamente como algo inferior a lo racional vinculado al espacio simbólico masculino, será reapropiado de manera positiva por parte de Manada Salvaje para enunciarse desde estos postulados, para revalorizar aquello que estaba despreciado en nuestras sociedades heteropatriarcales occidentales.

Otro de los factores que le llevaron a militar en la Manada, en los feminismos fue marcado por experiencias personales. La politización de lo personal, la politización de violencias, de dependencias, de opresiones, de dominios, el llevar lo personal a lo político a través del feminismo le hicieron romper las cadenas que le impedían volar:

"Lo que me ha llevado a actuar desde ahí... la verdad que mí contexto personal. No sé en qué momento yo me decido por el feminismo, no me acuerdo realmente. Ya que ha sido un proceso tan fluido que no recuerdo el momento exacto. Pero sí que, bueno, yo en mi casa he vivido malos tratos. O sea, no de palos, pero sí un maltrato psicológico, de mi padre a mi madre muy 
fuerte, de mi padre a nosotras también. Mis padres se separaron finalmente cuando yo tenía siete añitos... y luego también a medida que yo iba creciendo pues me iba dando cuenta de que todas mis amigas, todas tío, habían tenido una relación jodida en la que un tío le estaba machacando, incluso yo ¿no? Entonces yo creo que fue... que yo encontré en el feminismo las alas para echar a volar y romper con esa relación..."

El feminismo nos enseña a entender las relaciones personales de una manera completamente diferente a la que la sociedad y la cultura patriarcal nos ha inculcado. A través del feminismo, Elena muestra cómo ha aprendido a politizar sus relaciones, sus emociones y sentimientos.

Como he señalado con anterioridad, el lugar que ocupan las emociones a la hora de enunciar la lucha política de Manada Salvaje es central. De esta forma, Carmen señala que:

"Hablo desde muchos sitios, pero sobretodo hablo desde las emociones siempre. Intento hablar desde las emociones. Intento que nunca pase nada mental por mi cuerpo, aunque pasa y vivo con ello lo más cómoda posible. (...) Las relaciones afectivas es una cosa que me han marcado a lo largo de mi vida y la forma en la que he crecido, en la que he aprendido... eh... en la que soy un poco. Yo creo que soy un poco a través de las personas. Esa es mi teoría ¿no? Como que yo no existo. $Y$ entonces soy un poco lo que he vivido con mis relaciones afectivas, sexuales y no sexuales..."

Emociones, sentimientos, relaciones afectivas van conformando la identidad relacional de Carmen quien expresa en estas líneas como su identidad se construye en relación a Ixs otrxs. De esta manera, entiendo que Carmen muestra cómo su género, entre otros elementos constitutivos de las identidades, se construye en función de nuestra interacción con Ixs demás, en función de nuestra interacción en diferentes contextos, negando de esta forma cualquier premisa esencialista constitutiva de los géneros.

Otro de los aspectos fundamentales que han Ilevado a Carmen a construir Manada Salvaje son las ganas de crear, las ganas de interpretar. Su objetivo es transformar la realidad social desde la creación artística. Arte y política van da la mano. La función del arte que encontramos en el discurso de Carmen es la función de crítica social, de denuncia, de cuestionamiento de los parámetros normativos de nuestra sociedad:

"A mí siempre me ha encantado interpretar y hacer cosas... A nivel creativo siempre he tenido muchas ganas de hacer teatro. Es más, he estado siempre en teatro en mi pueblo. Y hasta que no encontré Manada no encontré un sitio donde poderme expresar, y además justo en la línea que yo quería ¿no? Que era... sí, con una perspectiva feminista."

La necesidad de expresarse y de sentirse cómoda haciéndolo es lo que Carmen consigue satisfacer en la Manada. A través de la expresión artística pretende no sólo mostrar sus emociones sino realizar una crítica al orden social establecido. 
Marina habla de tres puntos clave en su vida que le llevaron a desarrollar una militancia política desde estas posiciones y no desde otras. Tres principales factores, tres vivencias personales que le conformaron y le condujeron a interesarse por las cuestiones transfeministas:

"Hubo un punto muy clave en mi vida que fue en la Erasmus, y ahí me encontré yo por primera vez. Salí de mi espacio de confort y de mi historia, de mis roles establecidos en mi ciudad de origen ... por fin rompí con eso, y ahí por primera vez en un espacio completamente nuevo, con gente completamente nueva, yo empecé a mirarme hacia adentro y... iguau! empecé a encontrarme de alguna manera. Sí, quiero puntualizar que en la Erasmus me enamoré por primera vez de una chica... que creo que es super importante también ¿no? A parte de las luchas, de... establecerme un poco más. A nivel de identidad sexual fue super importante para mí."

El salir del lugar de origen, el conocer otras culturas, otras personas, le llevaron incluso a cruzar la frontera de la normatividad sexual y de género. Marina señala que el comenzar a tener relaciones con personas de su mismo género le guiaron a transformar su identidad sexual. Una vez más, podemos observar cómo de esta manera tanto la identidad de género y sexual muta o se transforma a lo largo de los procesos vitales. Del discurso de Marina se puede extraer la idea de la desnaturalización de la sexualidad puesto que como ella muestra ha ido cambiando a través de su interacción con otras personas. Así, podemos volver a afirmar que tanto la sexualidad como el género son construcciones sociales, fruto de procesos históricos y culturales.

Marina coincide con nosotrxs cuando interpreta el movimiento $15 \mathrm{M}$ como hito constitutivo de su subjetividad. El desarrollo de la conciencia política y social y la creencia en otras prácticas organizativas de acción, lucha y resistencia fueron tomando forma a partir de su militancia en el movimiento:

"Otro punto clave fue con el 15M y tal, que para mí son los dos momentos clave de mi vida y siempre los comento ¿no? Porque son los que a mí me han conformado; son dos experiencias clave de lo que hoy soy. Dos vivencias bastante importantes y bueno, pues seguí haciendo la carrera pero yo no encajaba. (...) Y ahí ya, entraron mis primeras reivindicaciones, mis primeras luchas ¿no? (...) En el 15M me volví a enamorar y después... como mi primera relación seria ¿no? Además fue de la portadora number one del 15M de allí en Jaén. Por eso son dos puntos clave. Realmente a la chica la conocí en Ecologistas en Acción, pero me enamoré el 15M, el 15 de mayo."

Además de la conciencia feminista que se iba fraguando en estos tiempos, Marina mantiene una clara conciencia ecologista, al igual que me han comentado sus compañeras. Comparten luchas por la defensa del medio ambiente y simpatizan con las propuestas decrecentistas. El 
"vivir mejor con menos", el respeto por la naturaleza y a los seres del planeta atraviesa las conciencias de Manada Salvaje como veremos más profundamente en el análisis de alguna de sus performances.

La llegada de Marina a Granada transforma su manera de estar en el mundo. Granada vuelve a actuar fuertemente en la construcción identitaria de quienes la habitan. Granada le permite tomar contacto con posiciones transfeministas y el hecho de estudiar un máster sobre migraciones, desarrollo e intervención social le brindan la oportunidad de acercarse a la crítica postcolonial. De esta manera, Marina comienza a forjar una conciencia ecologista, anticolonial y antiheteropatriarcal que expresará a través de sus performances con Manda Salvaje:

"Me vengo para aquí, para Granada, hago el máster del MEMDIS y tal... rompo con la relación anterior a distancia. Y aquí vuelve a ser otro punto importante en mi vida porque doy otro paso más allá. Que es a nivel más de transfeminismo ¿no? Aquí es cuando empiezo a conocer realmente... o a vivir más intensamente el tema de la deconstrucción del género, el tema Trans, etc. etc. Lo que podríamos denominar así a groso modo el Transfeminismo. $Y$ en el máster tengo la posibilidad de conocer a algunas profesoras como Ana Alcázar, que también me marcan mucho. (...) Empiezo a conocer ese mundo postcolonial que también en mi vida es super importante porque hasta ahora era el feminismo blanco, occidental el que había llevado yo un poco por bandera..."

\section{Lo que nos ha dado el (Trans)feminismo}

"Como ganas de... otra vez, de exponerme desnuda, de hacer cosas sexuales en público..."

(Carmen, MS)

Hasta el momento y siguiendo las pautas que nos ofrece Teresa del Valle (1995) para la realización de investigaciones centradas en lo auto, me he interesado en conocer cuáles han sido aquellos hitos o acontecimientos más importantes en nuestras vidas que nos han acercado a los feminismos, al transfeminsimo. Pero ¿Qué supone conformar un grupo con estas particularidades? ¿Qué supone la militancia en Manada Salvaje?

Elena lo tiene claro, encontró en el feminismo y en su manada respuestas, aperturas, nuevas miras. En definitiva, Elena señala que este tipo de activismo ha supuesto para ella un proceso de empoderamiento:

"O sea, encontrar en el feminismo respuestas a preguntas que yo estaba teniendo, o a situaciones que yo estaba viviendo. O sea, cuando yo empecé a leer sobre feminismo y empecé a ver como maltrato de libro ¿no? Yo decía: ihostia! Esto me está pasando a mí, que es super común ¿no? Es decir, ihostia! Que te digo yo, pues no sé... las típicas actitudes que tienes en una relación insana, pues dependencia, que te aparta de tus amigas, que no le gusta que 
salgas... ¿no? Esas cosas, yo empecé a leerlas y dije: ihostia! Es que a mí esto me está pasando y entonces me empezó un poco a abrir la mente. Y sí yo encontré en el feminismo alas, sí..."

Marina comparte ciertas sensaciones con Elena acerca de este proceso de militancia feminista:

"También yo creo que tenía muchos prejuicios internos que tenía conmigo misma, con mi cuerpo... cómo te lo explico... bueno con los parámetros normativos de cómo debe ser un cuerpo y yo pues siempre... creo que no había un momento que decía iqué cuerpo tan bonito tienes, quilla! De tenerlo super interiorizado... entonces era una manera también de romper con eso. (...)Y eso me ayudó a empoderarme de mí misma porque nos quedábamos completamente desnudas y decir ime da igual! iSoy preciosa!"

Empoderamiento vuelve a ser la clave para comprender la pertenencia a Manada Salvaje. EI transgredir los prejuicios sobre unx misx, el subvertir los parámetros de la normalidad, el estar a gusto con el propio cuerpo es fundamental a la hora de entender la militancia de Marina en Manada Salvaje. Sus acciones con la Manada le conducen a desaprender aquellos cánones de belleza tan estrictos y opresivos con los que el sistema heteropatriarcal penetra, específicamente aunque no sólo, a las mujeres.

Para Carmen ha supuesto retos, inquietudes, desafíos. Afirma que ella es muy sexual y que siempre ha tenido ganas de desnudarse, de ser observada sexualizada. Con sus ganas de interpretar, encontró en Manada Salvaje el lugar perfecto para la combinación de sexualidad, arte y política:

"Sí, como ganas de... otra vez, de exponerme desnuda, de hacer cosas sexuales en público, tenía muchas ganas de descubrir eso ¿no? De cómo me sentiría yo sexualizada y que mucha gente me mirase en público. Me apetecía mucho explorar eso. Y me sentí super bien.

Carmen transgrede, de esta manera, el rol patriarcal tradicional asignado a las mujeres, subvierte la imagen de mujer pasiva y sin deseos sexuales. Transgrede la idea de mujer objeto sexual cuando se desnuda en público y encuentra en ello placer, satisfacción, fantasías y cosas positivas. Subvierte la idea de la "buena mujer" aquella que es recatada y que no muestra sus deseos sexuales en público.

\section{Aproximación al contenido de las performances de Manada Salvaje}

"Porque la historia la escribe nuestro deseo. Somos manada, Manda Salvaje."

¿Qué lleváis dentro? ¿Qué queréis sacar? Este tipo de performances transgresoras, chocantes, desobedientes de lo normal tienen la capacidad de afectar tanto a quienes la desarrollan como 
a quienes la presencian. En ocasiones, rompen la frontera entre Ixs espectadorxs y lxs performers y así ocurrió esa noche de otoño granadino:

“Performance Pornoterrorista” (En el bar Sohno)

“Entonces lo único que puedo hacer es decir... Insumisión."

(Elena, MS)

Las primeras performances de Manada Salvaje surgen en el contexto del intento de reforma de la ley del aborto. Durante esos meses, el movimiento feminista vuelve a organizarse para oponerse firmemente a dicha reforma. A todxs nos pareció impensable que proclamas y reivindicaciones que había desarrollado el movimiento en décadas anteriores, tuvieran que revivir para resistir al ataque del neomachismo y conservadurismo encarnado en el gobierno del Partido Popular.

"Dijimos: ihostia! tenemos que seguir haciéndolo, que es que nos van a ilegalizar el aborto... Entonces ahí teníamos mogollón de rabia, mucha rabia, yo sentía mucha rabia, y mucha impotencia y mucha frustración. Entonces lo único que puedo hacer es decir... Insumisión ¿sabes? Y me pareció super simbólico lo de sacarnos los rosarios del coño que ya lo habíamos visto por internet, no fue nuestra idea. Pero eso de lanzarlo también ¿sabes? Eso, eso me encanta. Y me acuerdo de las caras de la gente al lanzarlo que fue como icoño!" (Elena, MS)

El discurso de Elena está cargado de rabia, de ira, de frustración, de impotencia y eso conduce a Manada Salvaje a actuar desde dichas posiciones emocionales. La performance que termina cuando todas comienzan a sacarse los rosarios del coño y al grito de "mi cuerpo es mío, donde yo mando" representa simbólicamente una resistencia a la apropiación por parte de la Iglesia o del Estado del cuerpo de la mujer. La rabia funcionaba como el motor de la lucha.

\section{“Performance Ole tu coño"103 (En la sala Bottom)}

"No follamos para reproducirnos, follamos porque nos encanta follar. (...) Decíamos que nos gusta meternos las manos, los puños, que nos chupamos, que nos encantan los flujos..."

(Carmen, MS)

La segunda performance de Manada Salvaje también se sitúa en el contexto de dicho intento de reforma patriarcal ${ }^{104}$. La rabia, el cabreo, la ira, la necesidad de expresarse en contra de las instituciones patriarcales salía de lo más profundo de la Manada:

"En la de la Bottom es que era la época del aborto. Entonces ahí yo estaba muy cabreada. $O$ sea, yo creía realmente que se iba a prohibir el aborto y yo recuerdo que llorábamos un

\footnotetext{
${ }^{103}$ El vídeo de esta performance puede consultarse en https://vimeo.com/88169415

${ }^{104}$ Fotos sobre la performance "Ole tu coño" pueden verse en el Anexo nำ.
} 
montón. Yo estaba asustada, pero asustada, asustada. Tenía rabia. (...)Entonces, ese momento fue una forma como de salvarme en ese proceso de tres o cuatro meses que me cagaba en todo..." (Carmen, MS)

En esta ocasión, Manada Salvaje combinó su crítica a dicha reforma con su crítica a la Iglesia, pilar fundamental para la reproducción del heteropatriarcado y grupo de presión para que este atropello contra la libertad de las mujeres saliese adelante. Esta performance consistía en una representación un tanto peculiar de la tradicional Semana Santa granadina. Cirio en mano, todas vestidas de mantilla ven aparecer a la virgen María sobre el escenario. Algo ocurre de repente, la virgen comienza a sangrar ¿pero qué pasa? Los allí presentes asistimos aquel día al aborto del niño Jesús delante de nuestras narices. Lejos de tristezas, la virgen María comienza una especie de orgía con el resto, quienes se quitan las mantillas para disfrutar de la ocasión y pasárselo estupendamente al ritmo de Putin lights up the fires del grupo de punk feminista Pussy Riot:

"Era más como empoderarnos de nuestra sexualidad, de nuestra... El control de nuestros cuerpos... el control de mi cuerpo, y el control de mi sexualidad y la libertad de hacer lo que me da realmente la gana." (Marina, MS)

"La idea era como intentar escapar de la imagen productiva de una mujer, o sea, relacionándolo con el aborto... decíamos no follamos para reproducirnos, follamos porque nos encanta follar ¿no? Porque nos gusta hacer tal, tal, tal... y al final reivindicábamos... no me acuerdo lo que decíamos pero... que nos gusta meternos las manos, los puños, que nos chupamos, que nos encantan los flujos, no sé, como muchas prácticas sexuales..." (Carmen, MS) $)^{105}$

La reivindicación del control de los propios cuerpos, la reivindicación de la propia sexualidad, de una sexualidad no normativa, grupal, combativa, transgresora... dejó bien claro que la sexualidad femenina va mucho más allá de la reproducción; la constituyen placeres, deseos, perversiones, inmoralidades, vicios, goces y desenfrenos.

\section{“Performance El aullido de las brujas” (En el Mini Club y en La Fábrika Crítica)}

"Nos pintábamos la cara con la sangre de la otra, la sacábamos del coño y nos pintábamos..."

(Elena, MS)

\footnotetext{
${ }^{105}$ El texto completo que escribieron para dicha performance es el siguiente: "Nosotras las mujeres follamos, nos comunicamos y creamos sexo. Por placer y con amor. A nosotras las mujeres nos gusta saborear, bebernos los fluidos vaginales, corridas y semen. Por placer y con amor. A nosotras nos gusta oler a sexo sucio, salvaje, en la cama o fuera de ella. Por placer y con amor. Nos gusta penetrar agujeros, bocas, ojetes y coños. Y también nos gusta que nos penetren con manos, dedos, puños y pollas de plástico. Amamos los cuerpos, nos follamos las mentes. La historia la escribe nuestro deseo. Somos manada, Manada Salvaje."
} 
Pasado un tiempo, las integrantes de Manada Salvaje transitan hacia otras posiciones tanto a nivel personal como a nivel artístico y este cambio se ve plasmado en la representación de su última performance:

Esta es ya más mística, más brujil. (...) Está un poco inspirada en el libro Mujeres que corren con los lobos. (...) Ella es feminista también, pero más mística. $Y$ está un poco inspirada en esta historia. $Y$ bueno, un poco contando que en el principio de los tiempos las mujeres y las lobas eras hermanas, y la luna pues las regía, entonces, pues llegó el sol como símbolo del patriarcado y rompió como los lazos que unían estas relaciones. Y rompían un poco pues la afectividad, el cariño, la empatía, todas las cosas que nosotras consideramos que hay que reivindicar, vaya. (...) Y sacábamos todo lo malo, nos poníamos como embrujadas y luego en una parte de la perfo quemábamos cosas como la sexualidad normativa, la educación sexista, los cánones de belleza y el miedo. Lo quemábamos todo. Y luego de la pócima les dábamos de beber a todas las hermanas que había en la sala. (Elena, MS)

Pretendían rescatar el papel de las brujas, resignificar la imagen negativa de las brujas, rescatar el conocimiento popular arrebatado por el patriarcado y el capitalismo y denunciar la opresión que naturaleza y personas (concretamente mujeres) sufren por parte del patriarcado y del capitalismo. La frase feminista y combativa que resumiría el contenido de esta performance sería la de "somos las nietas de todas las brujas que no pudisteis quemar". Al mismo tiempo que resignifican historias, figuras e imágenes, Manada Salvaje reivindica otros valores como el afecto, la emotividad, los sentimientos, la ternura, la empatía y se ve reflejado en el tránsito de sus posiciones vitales como veremos a continuación.

\section{Transitando a otras posiciones (Trans)feministas}

"Y esa rabia la tenemos que sacar de alguna forma."

(Carmen, MS)

Carmen me cuenta que ella ya no habla ni actúa desde la rabia, puesto que su discurso le había hecho discutir con sus familiares y amigxs. Prefiere hablar con las personas de lo que les une (ella lo describe como política del amor), ya no necesita provocar ni convencer a nadie, se centra en fomentar la empatía y lo vive como un proceso madurativo por el que no todas las personas tienen que pasar:

"Creo que no se trata la empatía en ciertos sitios, o el entender miradas diferentes... Al final de todo, creo que siempre es lo mismo, la rabia. $Y$ yo lo entiendo perfectamente, vamos, yo cuando he tenido rabia, no podía... y creo que muchas de nosotras tenemos rabia; es una putada ... por causa de este sistema de mierda que nos ha hecho acumular rabia desde muchos sitios desde la educación, desde la familia, desde ... Y esa rabia la tenemos que sacar de alguna forma. Entonces, ahora mismo yo no me siento ahí..." 
Al igual que Carmen, Elena apunta que no le hace bien el seguir con la rabia, no quiere herir sensibilidades y se sitúa desde la empatía. Realizan una crítica a ciertos sectores del feminismo por su dogmatismo e intolerancia y ambas prefieren intentar entender a las personas sin realizar juicios de valor. Han sufrido un proceso de cambio, han transitado desde la rabia hacia la empatía pues esta posición les hace estar mejor consigo mismas y con quienes les rodean:

"Bueno, porque he empezado a ver que hay una cosa de mí que a mí no me hace bien y que es el dogmatismo y la intolerancia. Entonces intento alejarme de los ambientes donde esas cosas están. (...) Pero es verdad que a veces como que se tocan fibras y sacan chispas, pues eso, de dogmatismo e intolerancia. $Y$ como muy desde la rabia. $Y$ ya te digo. A mí en este momento, y es por mí, no es por la gente que lo hace mal, sino porque yo tengo eso dentro de mí y no me gusta ni vivirlo ni sacarlo..."

Marina señala que en estos momentos lo que le interesa es la ternura, el reencontrarse con sus orígenes y buscar lo que nos une, aunque firmemente señala que sus prácticas no han cambiado; sí su perspectiva hacia Ixs demás puesto que ya no quiere imponer sino reflexionar y aprender con Ixs demás. Pretende buscar lo común con las personas y no centrarse tanto en lo que nos diferencia:

"Y tengo otro cambio importante que es que ya no estoy con el discurso político tan violento, sino que me vuelvo, o sea, pretendo reencontrarme con mi origen, y en vez de ir dando el discurso político pretendo reflexionar con las personas que quieren hacerlo conmigo ¿no? Cambió un poco mi forma de... a lo mejor de afrontar la vida ¿no? Con la gente que quiero porque me había distanciado mucho. Mi forma de pensar, mi forma de actuar, mi forma de ver las cosas me habían distanciado de familiares, amigas y amigos de toda la vida, que obviamente viven en un mundo más normativo y tienen unas prácticas que yo consideraba que esa no eran las prácticas que había que llevar, claro."

La rabia, aquel sentimiento que en tantas ocasiones nos ha servido a muchxs para empujarnos hacia la lucha, para crear, para producir, para desarrollar políticas y estrategias de resistencia, que ha guiado nuestra forma de estar en el mundo, que ha sido un factor fundamental para entender nuestras subjetividades, que tantas cosas positivas nos ha dado... puede mutar. En el caso concreto de Manada Salvaje se ha desvanecido en cierta medida para dejar paso a otras posiciones emocionales como la empatía, la exploración de lo que nos une con otras personas y la búsqueda de lo común.

\section{Situando los cuidados en el centro (del Transfeminismo)}

"Cuando vemos los cuidados en construcción colectiva vemos lo poco o lo nada o lo cero que cuida el sistema en el que vivimos."

(Marina, MS) 
A lo largo de este tiempo de investigación y de compartir experiencias y militancia política con mis compañerxs me he dado cuenta de que hay una cuestión central en nuestras interacciones: los cuidados. Este apartado pretende ofrecer algunas notas acerca de los cuidados desde nuestras posiciones transfeministas, pretende sumarse a los trabajos ya realizados que sitúan los cuidados en el centro. No es fácil llegar a un consenso colectivo sobre lo que significa esta palabra. Considero que está en constante devenir y en constante interrogación. Tampoco es fácil cuidar ni considero positivo que se mitifiquen los cuidados como algo solamente positivo que no cuesta trabajo ni esfuerzo. Pero sí que entiendo que los cuidados, a veces olvidados por nosotrxs, ocupan una posición central en nuestros discursos y se intenta que sean la base de nuestras prácticas diarias y políticas, de nuestra cotidianidad, de nuestra forma de relacionarnos con Ixs demás:

"Estoy, bueno, ya no, pero hace un par de meses que tuve una crisis bestial porque me di cuenta que a veces, nosotras mismas dejamos los cuidados de lado... y vamos te puedo poner de ejemplo el poliamor y tal. Me da coraje que somos feministas pero me enrollo con quien me da la gana y a veces no pienso en cuidar. (...) Por tanto, priorizo más que cualquier otra cosa, ahora mismo priorizo en mi vida el cuidado y la ternura y afecto."(Marina, MS)

Marina muestra cómo en ocasiones los cuidados son dificultosos y nada fácil de llevar a la práctica, pero enfatiza que deben ser la piedra angular de nuestras vidas tanto a un nivel más personal como a un nivel más político. Tienen que ser la base de nuestras estrategias de lucha, no podemos dejarlos solamente en el discurso, sino que deben guiar nuestras relaciones personales y nuestra militancia política. Continúa su discurso señalando que los cuidados son fundamentales para crear redes y concienciar:

"Creo que es una herramienta y una manera de ver las cosas que llega además a la gente, que es lo mejor de todo esto ¿no? (...)Y además cuando vemos los cuidados en construcción colectiva vemos lo poco o lo nada o lo cero que cuida el sistema en el que vivimos. Somos más conscientes de lo que realmente... de la opresión que vivimos cada día ¿no? Con el trabajo, vamos a repensar el trabajo, el concepto del tiempo, el propio concepto de cuidados ¿no? Vamos a repensar absolutamente todo..."

Entender los cuidados como algo colectivo nos hace conscientes del mundo opresor en el que vivimos y nos invita a repensar el trabajo, el tiempo y el propio significado de cuidados. En la misma línea, Carmen enfatiza los cuidados como lo primordial:

"Pues los cuidados me parecen básicos, vamos, eso lo primordial. (...) Y luego... vamos, vivir en comunidad, vamos. Yo... es el futuro. Y en cuanto a lo que decíamos cuando una se pone mala... yo lo dejo, yo le cuido. Por ejemplo, alguien se pone malo y no tiene nadie para cuidarla y no puede estar sola... digo que no voy a las prácticas, o sea, intento dentro de la formalización, intentar adaptarme a los tiempos de nosotras ¿sabes? Y sé que a veces para algunas es difícil 
cuando tienes un curro que no puedes decir que faltas, pero dentro de la exigencias que yo tengo ahora mismo en mi vida, o sea, lo primordial ahora mismo es cuidarse."

Aun asumiendo los cuidados como lo primordial, Carmen es consciente, y así lo muestra, de la dificultad que podemos encontrar a la hora de realizar esta experiencia de cuidados debido a las imposiciones laborales capitalistas. Entiende las formas comunitarias de organización como la herramienta clave para poder vivir cuidándonos. El discurso de Elena se suma a pensar la comunidad como una de las posibles estrategias de resistencia a las opresiones heteropatriarcales y capitalistas:

"Pues mira, yo pienso que justamente lo de tejer redes o crear comunidad es la clave ahora mismo, no sólo para sobrevivir sino para vivir. Porque creo que es lo que se nos había olvidado en general a la sociedad. Y justamente gracias a la crisis, para mí la crisis es bendita, bueno, a ver, salvando la peña que está muy jodida, pero es verdad que nos está dando la oportunidad de darnos cuenta de un montón de cosas que sin la crisis no nos hubiéramos dado cuenta. (...) Para mí la clave está en crear comunidad, crear comunidad frente a la precariedad."

La crisis nos ha mostrado cómo vivíamos y la necesidad de transformar nuestras formas de organización social. Entiende la comunidad como la clave para afrontar la precariedad que constituye nuestras existencias. Apuesta por valorar la empatía y tejer redes. Una vez más, Marina nos invita a la reflexión y apunta algunas indicaciones sobre cómo repensar lo común desde nuestras posiciones transfeministas:

"Primeramente, visibilizar el daño que nos estamos haciendo viviendo en este sistema. Que reflexione la gente de lo que supone realmente levantarse todos los días a las 8 de la mañana para ir a un trabajo de mierda y... el tiempo, la pobreza del tiempo, no sé si es Amaia o Sira del Río... pero me parece muy interesante ese concepto de que el tiempo no debemos medirlo a nivel material o a nivel monetario sino la libertad de nuestro tiempo. (...) A lo mejor si fuéramos más libres de decidir sobre nuestro cuerpo, sobre nuestra sexualidad, sobre nuestro trabajo, sobre nuestra forma de organizarnos diariamente tendríamos más... tiempo real... (...)Luego la forma de crear redes entre nosotras me parece super importante. Y el empatizar."

En el discurso de Marina podemos observar una crítica a las condiciones laborales del actual sistema capitalista de producción. Este sistema que nos ha hecho confundir el tiempo del trabajo con el tiempo de la vida nos ha conducido a no comprender otros valores como el de la libertad de tener tiempo para desarrollarnos como personas al margen del sistema productivo. Marina considera que es necesario hacer llegar a la gente una reflexión sobre el tiempo que dedican a sus trabajos y el poco tiempo que dedicamos a otras actividades importantes para la vida, precisamente por esa dedicación laboral. 
Puesto que parte de los objetivos de esta investigación es la reflexión sobre lo común desde nuestras posiciones transfeministas, he considerado oportuno finalizar mis entrevistas con una cuestión que lanza Silvia L. Gil acerca de estos temas. Mi pretensión es entrar en diálogo con Silvia L. Gil y Amaia Pérez Orozco ${ }^{106}$ a través de las reflexiones que mis compañerxs desarrollan sobre estas cuestiones. Gil plantea que "en cualquier caso, lo que está en juego no es tanto señalar quiénes serían los sujetos a los que interpela el transfeminismo, como si se están recogiendo problemas comunes que afectan a diferentes sujetos, que nos permitan pensar de otro modo, uno transformador, lo que nos rodea" (2011, p. 176).

Ante este debate, Elena afirma que el transfeminismo sí está recogiendo problemáticas comunes que afectan a diferentes sujetos pues su perspectiva interseccional permite dar cuenta de las diferentes categorías que conforman las identidades:

"Completamente. Es lo que te he dicho antes. Para mí el transfeminismo es el paso siguiente del feminismo. Es lo que recoge las casillitas que nos conforman y no sólo nos conforma el género, nos conforman muchas más cosas ¿no? Como la precariedad... o la comunidad."

Carmen señala que el transfeminismo sí que se está preocupando por problemáticas que antes eran invisibilizadas u obviadas por ciertos sectores del feminismo, pero que todavía quedan muchas cosas que el movimiento no recoge. Al igual que Marina, su preocupación se centra en por qué el transfeminismo o los feminismos en general no llegan a sectores de la población que no han pasado por la universidad y enfatizan el lenguaje como uno de los principales obstáculos que dificultan la llegada de las ideas transfeministas a otros sectores poblacionales:

"Se están recogiendo cosas que antes no se recogían ¿no? Y hay muchas problemáticas que antes quizás no se recogían y ahora sí se recogen. Pero creo que hay muchas cosas que se dejan en el tintero. (...)Entonces creo que hay un fallo en el transfeminismo, en el feminismo que todavía no ha llegado a personas que no tengan formación."

"A nivel teórico, por supuesto que sí, que sí que apela a muchísimos sujetos. ¿Por qué no llegamos? Esa sería mi pregunta. Y creo que a lo largo de todo este rato te he ido soltando... Creo que no llegamos muchas veces porque el discurso como tal, además como los conceptos feminismo, patriarcado... la gente chirría con eso. Creo que es más bien adoptar la actitud de empatizar con las personas para conectar con la gente, pero si sé que yo no tengo la verdad absoluta, además soy una puta privilegiada... puta y privilegiada."

Recojo como cierre de este pasaje el mensaje principal al que Manada Salvaje nos invita. Es el mensaje de revitalizar los afectos, las emociones, la empatía, los sentimientos, la ternura pero no desde posiciones esencialistas asociadas a lo femenino, sino como algo que deberían

106 El debate que plantean sobre transfeminismos y lo común puede consultarse en https://www.diagonalperiodico.net/la-plaza/transfeminismo-sujetos-o-vida-comun.html 
desarrollar todas las ficciones identitarias. El buscar vínculos con los demás. El alejarnos de posiciones dogmáticas e intolerantes e intentar indagar sobre aquello que nos une con las personas. En definitiva, entiendo que al igual que Amia Pérez Orozco o Silvia L. Gil, Manada Salvaje nos invita a buscar lo común y a repensarlo, reflexionarlo, cuestionarlo. Siempre visibilizando y teniendo en cuenta las diferencias que nos configuran como sujetos, comprendiendo la intersección de opresiones, privilegios, vivencias, experiencias, trayectorias que componen nuestras identidades a través del género, la sexualidad, la raza, la clase, o la diversidad funcional entre otras; pero haciendo un esfuerzo para desarrollar prácticas colectivas de transformación social, prácticas comunitarias, nuevas formas de pensar lo político, nuevas formas de organizarnos situando como pilar fundamental o cimiento de nuestra organización social a los cuidados. Las formas comunitarias de organización se erigen ahora más que nunca como necesarias para afrontar las diversas violencias y opresiones que el sistema genera sobre nosotrxs. En un sistema heteropatriarcal y capitalista que ataca a la vida de una manera feroz, rescato de Manada Salvaje la idea de entender los cuidados como lo primordial, los cuidados a la vida de las personas y al planeta como lo fundamental y lo indiscutible para así transformar las condiciones materiales y simbólicas de existencia que nos constituyen.

\subsection{La construcción de una Fábrika (Crítica) que no aliena, no explota, no controla ni vigila}

"Estábamos hartas un poquito de la ranciedad del feminismo blanco, burgués, super educado y queríamos darle un poquito la vuelta a eso."

(Kris, LFC)

La Fábrika Crítica ${ }^{107}$ es otra "manada de perras" que lleva trabajando como colectivo en las luchas queer y transfeminista en Granada desde 2013. Aunque sus integrantes son tres, Kris, Karol y Lola, se nutre de redes de compañerxs que habitan la ciudad con las que comparten sus posiciones vitales y políticas ${ }^{108}$.

Hasta llegar a La Fábrika Crítica, primero debemos prestar atención al proyecto Eskándalo Púbico $^{109}$, una revista digital queer-transfeminista que surge unos meses antes a partir de diversas subjetividades rebeldes que habitaban Granada. Este proyecto aborda varias de las cuestiones que hemos tratado a lo largo del texto:

\footnotetext{
${ }^{107}$ La página web del proyecto puede consultarse en http://lafabrikacritica.com/

${ }^{108}$ Fotos y carteles de La Fábrika Crítica pueden verse en el Anexo № 9.

${ }^{109} \mathrm{El}$ contenido de Eskándalo Púbico puede verse en https://eskandalopubico.wordpress.com/. El Manifiesto de Eskándalo Púbico puede consultarse en el Anexo no 2.
} 
"queríamos darle una vuelta al feminismo este de las mujeres. O que el sujeto político feminista es la mujer... y de nunca creo que con las chavalas que me encontré teníamos esa perspectiva y casi todo lo que hacíamos era para darle la vuelta al sujeto político feminista. Y ahí coincidíamos genial todas y yo creo que de ahí surgen los proyectos tanto de Eskándalo púbico como de La Fábrika." (Kris, LFC)

A algunxs de Ixs integrantes de Eskándalo Púbico, les surgió la necesidad de generar un espacio en la ciudad de Granada que por un lado fuese constante, y así intentar sobrellevar el tránsito de personas y proyectos que configuran la ciudad, y por otro, ofrecer actividades de carácter transfeminista en otros puntos de la geografía del estado, puesto que la mayoría de ellas se producían en Madrid o Barcelona:

"El proyecto de la Fábrika surge cuando nos sentamos y dijimos, bueno vamos a montar una asociación, un proyecto de formación que vaya sobre estos temas, hacerlo desde nuestra política transfeminista y queer y bueno, hacer como actividades, tallercicos para currar estos temas que a nosotras nos parecen muy importantes... y ya después... empezamos a hablar de este tipo de proyecto, de que podríamos hacer talleres con más continuidad, para sacarnos también pelitas... porque claro estábamos en una posición muy precaria." (LoLa, LFC)

Por tanto, la Fábrika inspirada en la filosofía Do it your self surgió por diferentes motivos: el de realizar actividades con contenidos queer y transfeministas en la ciudad de Granada y de esta forma generar espacios de reflexión y de acción en torno a estas cuestiones. Por otro lado, surge como un espacio de formación donde producir conocimientos de manera colectiva, horizontal y desde lugares diferentes a la Academia; y finalmente, como proyecto para afrontar la precariedad que constituye las existencias transfeministas, con intenciones de autoempleo. El proyecto fue mutando y transformándose a lo largo del tiempo. Tras las primeras actividades, se optó por abrir un espacio físico donde realizar estas acciones. Junto al proyecto de La Otra Eskuelita de foto ${ }^{110}$, en octubre de 2014 decidieron dedicar todas sus fuerzas, tiempos y energías a la creación de este espacio físico. Han sido numerosas las jornadas y actividades realizadas a lo largo de este tiempo: talleres, charlas, cine-forums, aquelarres, peri-ferias, presentaciones de libros, autodefensa feminista, acompañamiento sexológico, muy diversos proyectos cuyos contenidos iremos abordando a lo largo de este pasaje. La Fábrika ha sido lugar de encuentro, de reunión, de creación y de producción del activismo transfeminista granadino y de otras partes del estado. Pero antes de continuar con los contenidos que dicho proyecto encarna, detengámonos en las motivaciones personales que lo han hecho posible puesto que de lo personal llegamos a lo político, desde el itinerario biográfico a lo colectivo:

${ }^{110}$ Puede consultarse en https://otraeskuelitadefoto.wordpress.com/ 


\section{Hitos que nos conducen al (Trans)feminismo.}

"Y ya no hay marcha atrás, Diega, ya no hay marcha atrás... eso es lo peor... que esto es un suma y

¿Qué os ha conducido a hacer este tipo de políticas?

"Bueno, yo creo que un sentirse sola en varios aspectos. El tema del género ha estado muy presente en mi familia. Es algo que ha ocupado mucho en mí desde siempre. Bueno, nunca he ocupado un lugar de una buena mujer, como se supone que tenía que ser. Todos mis hermanos son mayores, mi hermana sería como el modelo de la feminidad a seguir a tope. Un recuerdo constantemente por parte de mis padres de cómo tenía que ser, y yo sabía perfectamente de pequeña que yo no era eso, y sentirme mal... Yo creo que desde siempre como que he buscado espacios que me hicieran sentir un poquito que no estaba sola." (Kris, LFC)

Kris cuenta como desde pequeña se ha sentido desencajada en los círculos normativos de la sociedad puesto que no cumplía con los patrones y exigencias que se requieren a una "buena mujer". La politización de experiencias personales hizo que Kris comenzase a militar en diferentes movimientos sociales. Primero en el movimiento anarquista donde empezó a desarrollar un discurso y una forma de vida crítica con el capitalismo y la globalización. Pero diferentes vivencias machistas y la poca importancia que estos colectivos le daban a la sexualidad, hicieron que Kris apostase por la lucha feminista, como lucha integradora que desestabiliza los diferentes sistemas de opresión:

"Primero vamos a cambiar el mundo y luego ya vemos que hacemos con las relaciones ¿no? Ya mí, bueno, me parecía vital que si no veíamos lo que estábamos haciendo con lo personal jamás íbamos a poder generar sociedades o intentos de sociedades en los que estuviéramos bien." (Kris, LFC)

Algo similar le ocurrió a Lola. Tenía grandes ganas de organizarse colectivamente pero no encontraba ni en los movimientos LGTB, ni en los feminismos más tradicionales su lugar. Los primeros porque pecaban de poco feministas y Lola cuestionaba sus posturas asimilacionistas e integracionistas. Los segundos, porque no prestaban suficiente atención a las disidencias sexuales y trataban estos aspectos de manera superficial:

"Entonces era como homofobia, lesbofobia, transfobia por un lado; por otro lado, era no sentirme cómoda y luego pues mis decisiones de proyectos personales, académicos y laborales pues me he ido conectando más con gente que está en lo mismo que yo, que está en la disidencia sexual... bueno, en contra de la normativización de la sexualidad también..." (Lola, $L F C)$ 
Granada vuelve a ser hito constitutivo de las subjetividades transfeministas. Tanto Lola, como Kris afirman que su llegada a esta ciudad les permitió crear redes, de(construirse) personalmente y consolidar acercamientos políticos adentrándose, de esta forma, en las formas de vida y de crítica transfeministas:

"Fue a partir, bueno, empecé a estudiar, o sea todo esto de los feminismos, el cuestionamiento de las dicotomías de género, todas estas cosas como que me removían desde hace muchos años, desde que empecé la universidad aquí en Granada." (Lola, LFC)

"Soy activista feminista desde hace mucho tiempo, no te puedo decir una fecha. Creo que desde que empecé en movimientos sociales que puede ser a los 16 años. Desde que vengo a Granada pues sí que he tenido experiencias más colectivas transfeministas, es decir, como que he colectivizado más toda esta política y hemos hecho cosas también hacia fuera y hacia adentro." (Kris, LFC)

El estudiar cuestiones relacionadas con los géneros y las sexualidades y el verse que cada vez encajaban menos en los patrones y espacios normativos de la sociedad, le llevaron tanto a Kris como a Lola a organizarse $y$, de esta manera, generar redes de resistencia tanto afectivas, emocionales, como políticas y organizativas:

"Yo creo que sí, el sentirme un poco fuera de la normalidad. Yo creo que por género, sexualidad, precariedad y no querer conformarme con eso, no querer tragar, no querer estar en círculos normativos... sentirme desencajada." (Kris, LFC)

"Pero fue sobre todo a través del máster cuando ya sí que estábamos ahí un grupo de tipas dedicando nuestra energía, nuestro dinero, nuestro estudio, nuestras tesinas ¿no? Nuestro tiempo directamente al feminismo. $Y$ ahí fue cuando yo empecé concretamente a sentirme en colectivo". (Lola, LFC)

\section{Lo que nos ha dado el (Trans)feminismo}

"Me ha supuesto mucha renuncia a privilegios, me ha supuesto vivir de otra manera, me ha supuesto estar abierta a críticas constantes..."

(Kris, LFC)

Ambas activistas coinciden con al mostrar como el transfeminismo nos ha cambiado la vida en numerosos sentidos. Deconstrucciones y construcciones vuelven a ser clave para entender la militancia de Kris y Lola en este movimiento. Una vez picadas por la cobra transfeminista, no hay antídoto que consiga neutralizar el veneno que recorre nuestras venas:

"Pues una forma de vida. $Y$ orientar mis proyectos personales, y profesionales y económicos hacia esto porque es lo que me mueve, me remueve y lo que me merece la pena. Entonces es como que ha supuesto que todo lo haga desde y hacia ahí. Y luego a nivel de relaciones personales, pues bueno cuestionarte todo, cómo nos relacionamos, cómo lo hacemos... no 
solamente hablar de relaciones de poder del tipo que sea... o la intersección de todo, si no en tu día a día, en tus relaciones con tus compañeras, con tu familia en... O sea, lo atraviesa todo..." (Lola, LFC)

"Todo, me lo ha aportado todo. A mí me ha cambiado la vida. Es que me ha cambiado la vida. Me ha aportado encontrarme con gente con la que quiero seguir construyendo, me aportado una reflexión autocrítica y autoconsciente de cómo quiero vivir mi vida, cómo hacerlo un poco acorde con lo que pienso, creo y quiero generar, me ha aportado un cambio en mis relaciones afectivas, emocionales, amistosas, familiares..." (Kris, LFC)

Como me comentaba Lola, ya no hay marcha atrás. El transfeminismo nos ha supuesto el cuestionamiento de privilegios, de opresiones y nos ha cambiado nuestra forma de estar y comprender el mundo. El cambio en nuestras formas de relacionarnos con Ixs demás es fundamental a la hora de entender cómo el transfeminismo nos atraviesa.

\section{La Fábrika como espacio de (de)formación, producción y activismo}

"Abrimos un espacio horizontal de colectivización de conocimientos."

(Kris, LFC)

La primera actividad pública que realizó La Fábrika como colectivo fueron unas Jornadas Feministas de Granada ${ }^{111}$ durante el mes de febrero y marzo de 2014. El objetivo principal de estas jornadas era el de crear redes feministas en la ciudad. Son muy diversas las experiencias feministas de Granada y La Fábrika se propuso en este encuentro el construir redes a partir de experiencias, trayectorias y vivencias muy diversas. Así fue como se dieron a conocer. El colectivo al que yo pertenecía, Las Perras Marcelinas, también participó en dicho encuentro y supuso para nosotrxs la posibilidad de generar alianzas con experiencias afines. Tras el éxito de estas jornadas, la necesidad de crear un espacio físico queer-transfeminista en la ciudad cada vez se hacía más grande:

\section{(De)formación}

La Fábrika supone una apuesta por generar conocimientos construidos colectivamente desde los márgenes, desde la calle, desde experiencias y vivencias del activismo transfeminista granadino, entendiendo que no sólo desde la Academia se produce conocimiento:

"Pero sí, entonces, curramos todo esto de la formación, de la deformación, de la producción colectiva... Deformación de desaprender lo que hemos aprendido y vamos a reestructurarnos

\footnotetext{
${ }^{111}$ En los diversos talleres que La Fábrika organizó durante estas jornadas se trabajaron temas relacionados con la producción y (de)construcción del género, el sexo y las sexualidades, con aspectos relacionados con el aborto y los derechos sexuales y reproductivos y con la intención de tejer genealogías feministas.
} 
de alguna manera y vamos a ver que la formación no solamente se da en la Academia, no solamente se da en determinados... a través de élites que tienen los espacios, los dineros, que tienen los medios ¿no? Los lenguajes, los códigos..." (Lola, LFC)

Al utilizar el término (de)formación, se hace hincapié en que uno de los objetivos de este proyecto es la deconstrucción de diferentes normatividades, discursos y prácticas que hemos incorporado a lo largo de nuestros procesos vitales. Se pretende construir conocimiento desde experiencias encarnadas. Este espacio ha supuesto para nosotrxs el cuestionamiento de nuestros privilegios, la identificación de nuestras opresiones y la necesidad de generar redes de resistencias colectivas, afectivas y políticas.

\section{Producción}

La producción del conocimiento construido colectivamente se realiza a partir de metodologías participativas y horizontales con el fin de desestabilizar los grandes paradigmas de la ciencia, de la autoridad o del positivismo. Se apuesta por construir un conocimiento "otro" con metodologías "otras":

"Y sí, yo creo que metodologías clave son relaciones de poder, privilegios, deconstrucción de la jerarquía... un poquito desde perspectivas y metodologías ¿no? Que creo que es algo importante de La Fábrika que tenemos metodologías no normativas. O que no nos asumen a la gente que damos los talleres como "las que forman" ¿no? Sino que abrimos un espacio horizontal de colectivización de conocimientos y nosotras pues igual guiamos para ver qué cosas se generan. Esas metodologías me parecen potentes, subversivas..." (Kris, LFC)

\section{Activismo}

Como nos muestra Lola, el activismo es algo que va intrínseco en las subjetividades que conforman la Fábrika: "Activismo pues es lo que nos atraviesa vivencialmente".

Este espacio ha servido para la articulación de numerosas estrategias de resistencias, de producciones colectivas, de generación de redes, de vínculos afectivos, emocionales y políticos. El cuestionamiento de diferentes lógicas de poder se entrelaza con la apuesta por la deconstrucción de jerarquías y exclusiones, del pensamiento binario y de las tecnologías normativas de producción de género, cuerpo y sexualidad.

Son muy diversas las temáticas que encarna este proyecto. Las teorías queer y la teoría postcolonial sirven de base teórico-filosófica para trabajar temas relacionados con el cuerpo, las sexualidades, el género, los privilegios, la diversidad funcional, la represión, la postpornografía, el arte, las tecnologías de producción, reproducción y deconstrucción como el vídeo y la foto, haciendo críticas integradoras hacia el capitalismo, el colonialismo y el 
heteropatriarcado. Todas estas temáticas están articuladas conjuntamente, pero para un análisis más claro de las mismas, yo he optado por diferenciarlas en este texto:

\section{Sexualidades como piedra angular}

"Para mí es eso, sacar la sexualidad de lo privado, sacarla de las camas y... hacerla política."

(Lola, LFC)

Ya hemos abordado como la sexualidad ocupa una centralidad en el movimiento transfeminista y en las prácticas queer puesto que entendemos que el sistema heteronormativo configura el resto de esferas de la vida. Así, uno de los temas clave en las actividades de la Fábrika son aquellas relacionadas con las sexualidades. Desde este espacio se entiende la heterosexualidad como régimen político y económico, se cuestiona la matriz de inteligibilidad imperante, y se apuesta por generar imaginarios y prácticas no normativas que giran en torno al postporno, al poliamor, al BDSM, etc.

"En primer lugar tratamos el concepto de sexualidad de forma amplia, en plural, sexualidades y también de forma placentera, divertida, plural... trabajando mucho los estereotipos en relación a las sexualidades. Trabajando, deconstruyendo esa visión negativa de las sexualidades y su vinculación con las enfermedades y con las infecciones de transmisión sexual... Trabajamos la sexualidad por otro lado como un sistema político impuesto desde la heterosexualidad y el coitocentrismo. $Y$ también trabajamos la sexualidad desde ampliar imaginarios y ahí es por ejemplo cuando metemos el tema de la postpornografía, el poliamor, BDSM..." (Lola, LFC)

Desde La Fábrika se politiza la sexualidad ${ }^{112}$ entendiéndola no (sólo) como un aspecto privado de nuestras vidas, sino que la misma está atravesada por diferentes lógicas capitalistas, heteronormativas y coitocentristas. Se cuestiona la división binaria de sexualidad saludable/perversa, normal/patologizada apostando por construir relaciones sanas, seguras, consensuadas y placenteras.

\section{Cuerpo}

"Cómo la carne se hace migrante, cómo la carne se hace mujer, trans..."

(Lola, LFC)

El cuerpo ocupa una posición privilegiada en los discursos y prácticas transfeministas de La Fábrika. Es el lugar a través del cual nos relacionamos, experimentamos, sentimos opresiones y podemos generar resistencias. El cuerpo se entiende como un espacio político ${ }^{113}$, constructo

\footnotetext{
${ }^{112}$ Un ejemplo de politización del placer sexual como herramienta subversiva y empoderante puede verse en Checa (2011).

${ }^{113}$ Una interesante aproximación que entiende los cuerpos como espacios políticos y de resistencia puede verse en Martínez (2012).
} 
del poder, pero soporte para la resistencia crítica a través de la reapropiación de dichas tecnologías que nos producen:

"Es que para mí somos cuerpo, experiencia y cuerpo, es lo irreductible, lo material... entonces desde mi punto de vista trabajamos ahí porque es desde donde nos relacionamos y cómo nos relacionamos... y por otro lado, también lo trabajamos como un ámbito teórico, como un espacio político, lo trabajamos como... en todos los talleres le damos vuelta a esto de cómo producimos y construimos nuestros cuerpos desde ideologías, desde mecanismos de poder, pues cómo se materializan en nuestros cuerpos en torno al sexo, la raza, la sexualidad, la capacidad, a la nacionalidad, a los procesos migratorios. Cómo la carne se hace migrante, cómo la carne se hace mujer, trans... eso lo trabajamos pero no sólo como lugar donde asumimos el poder o se expresan relaciones o estructuras de poder; sino también como un espacio político." (Lola, LFC)

\section{Género como dispositivo de poder}

"El género como violencia en sí mismo."

(Lola, LFC)

Desde el transfeminismo se trabaja el género desde diferentes lugares. Por un lado, ya hemos visto que entendemos el género como una identidad performativa y como producto de una serie de tecnologías del poder. Por otro lado, como nos muestra Lola, se entiende el género como violencia, como sistema de opresión.

"El género lo tocamos también en todos lados. Lo tocamos como categoría social, como construcción sociocultural, pero sobretodo lo tocamos como una dicotomía... pues... o sea tocamos el género como violencia en sí mismo. No la violencia de género, que también, que también porque hemos sido construidos como hombres y mujeres, existimos como hombres y mujeres y tenemos diferentes opresiones y privilegios en relación a ellos. También lo abordamos desde ahí. Pero siempre en los talleres intentamos ir como más allá. Es que el temazo es el género como violencia que encasilla nuestros cuerpos y todo lo que está asociado a esto ¿no? Como que la clave para nosotras esta en eso." (Lola, LFC) $)^{114}$

En todos los talleres realizados por La Fábrika, se aborda el género desde estos lugares diferentes. El objetivo es mostrar cómo nos construimos como hombres y mujeres de manera performativa y cómo esto es una imposición violenta del mandato heteropatriarcal, que entre otras cosas, invisibiliza o violenta otras formas de estar en el mundo que no se pueden inscribir en dichas categorías binarias.

\footnotetext{
${ }^{114}$ En la misma línea, Miram Solá entiende "el género como un dispositivo de poder que impone de forma rígida, violenta y jerarquizada las categorías de hombre/mujer y masculino/femenino con el fin de producir cuerpos que se adapten al orden social establecido" $(2009$, p. 1).
} 


\section{Privilegios}

"Y es que el transfeminismo pretende cargarse los privilegios del sistema jerárquico."

(Kris, LFC)

Otro de los temas centrales que se han trabajado en la Fábrika es la cuestión de los privilegios. Son numerosas las formas en las que se han tratado. En el taller al que asistí sobre postcolonialismo, a través de las lecturas de Anzaldúa, Mohanti, Audre Lorde o Bell Hooks nos cuestionamos nuestras posiciones privilegiadas (no sin obviar nuestras opresiones), viendo que estamos compuestxs por un entramado complejo en intersección:

"Y creo que vuelca la base de un feminismo más hegemónico... Y es que el transfeminismo pretende cargarse los privilegios del sistema jerárquico. Para mí el tranfeminismo es pues cuestionarme mis privilegios como blanca, europea... ¿sabes? Tengo dos carreras y he estudiado un máster... pues es como renunciar a mis privilegios, para mí es eso. Lo que me hace es no dar pasos creyendo que ya está todo hecho o que yo tengo una palabra más importante que otras, o que yo porque he estudiado en la Academia. (...) Es algo que tiene en cuenta conocimientos y experiencias encarnadas ¿no? Y que se pueden generar mogollón de alianzas." (Kris, LFC)

Desde lugares situados, desde nuestros cuerpos, activismos o formas de producir conocimiento, a lo largo de este tiempo, se ha realizado un cuestionamiento a la epistemología eurocéntrica y occidental, a sus estructuras de poder y a sus dinámicas opresoras y colonialistas.

\section{Represión}

"Yo siempre digo que no servimos de nada ni en cárceles ni en psiquiátricos ¿sabes? Así que vamos a buscar la estrategia de no estar ahi."

(Kris, LFC)

Durante el período de observación (y militancia) he presenciado la llegada de la policía al espacio dos veces. La primera de ellas fue durante la presentación del libro Coño Potens de Diana J. Torres y del proyecto crítico con la ginecología patriarcal Anarchagland ${ }^{115}$ de Klau Kinki. La segunda de ellas, fue durante las jornadas de "artivismo" transfeminista realizadas el pasado mes de mayo. Estas "visitas" coinciden en el tiempo con la represión que los movimientos anarquistas y libertarios están padeciendo en el estado. Aun sabiendo que en el espacio está todo "en regla", que no se infringe ninguna norma, el simple hecho de la presencia de la policía genera incomodidades (eufemismo) puesto que sería muy dificultoso afrontar multas desde las subjetividades precarias que constituyen La Fábrika. No ha habido

${ }^{115}$ Puede consultarse en http://anarchagland.hotglue.me/ y en http://anarchagland.tumblr.com/ 
represión económica, pero el espacio se hizo visible para la policía y era precisamente lo que no se pretendía.

La Fábrika es un espacio donde se han trabajado estas cuestiones a partir de diferentes actividades. Sirvió de inicio de las jornadas anticarcelarias que se desarrollaron en Granada durante el mes de abril y se han realizado talleres que trataban la represión en el espacio público o que exploraban la conexión entre el capitalismo, el género y la represión.

Kris muestra como la ola generalizada de represión de los movimientos sociales y políticos afecta a numerosos sujetxs en nuestra ciudad, a aquellxs que no son útiles para convertir las ciudades en escaparates para el turismo. Estas dinámicas responden a lógicas globales capitalistas, pero se sitúan en contextos específicos locales donde se están gestando las mal llamadas ordenanzas cívicas. El objetivo de las mismas es la represión de sujetxs que por diferentes características somos peligrosxs para el sistema: trabajadorxs sexuales, personas sin hogar, activistas, artesanxs, músicxs, y un largo etcétera que encarnamos sus consecuencias ${ }^{116}$ :

"Yo creo que hay algo que es verdad que está pasando mucho más agudo desde el 2009 desde que sale la ordenanza cívica. Claro está que la ordenanza cívica es super explícita en este tema. Prohíbe absolutamente cualquier actividad que no sea consumir en la calle o transitarla, o sea, hacer ruido, jugar con una pelota, con la bici, ir con perro, demostraciones públicas de la sexualidad. Se refiere a las trabajadoras sexuales dicen, pero está puesto demostraciones públicas de la sexualidad. ¿Eso qué es? Que en el momento que a ellos se les vaya la flapa y si yo le doy un beso a mi compi y no les mola me van a... ¿sabes? ¿Cómo podemos permitir que tengamos ordenanza cívica de esa manera? ¿Qué es cívico? Y ¿Qué me estás contando? O sea, esa que convivencia es... Es que hay mucha gente que no se pude permitir ni sólo consumir, ni sólo transitarla. Hay peña que vive en la calle, que trabaja en la calle, que se tiene que buscar la vida ahí y todo eso está pues super reprimido. Y las corporalidades sospechosas de no transitar o consumir pues están alejadas, reprimidas..." (Kris, LFC)

\section{Cuidados y el cierre del espacio físico}

"No estaría aquí si no estuviesen estas relaciones colectivas."

(Lola, LFC)

Los cuidados vuelven a ser un tema importante para comprender las subjetividades transfeministas. Tanto Kris como Lola otorgan una centralidad a los cuidados en sus relaciones afectivas, emocionales, políticas y colectivas:

"Los proyectos en los que he participado o estado más implicada ha pasado por esto, ha pasado por las relaciones, por los cuidados, los descuidados, por el cariño, por la filias, por las

\footnotetext{
${ }^{116}$ Para un análisis de las lógicas de la represión situadas en el espacio público de la ciudad de Granada y de las diferentes estrategias de resistencia véase García (2013).
} 
fobias... ¿sabes? Es que ha estado marcado por eso. ¿Cómo vivo yo este activismo transfeminista desde donde me defino? O sea, las temáticas en las que curro, las áreas y los proyectos en los que estoy han sido decisiones personales pero marcadas por relaciones. No estaría aquí si no estuviesen estas relaciones colectivas. $Y$ creo que muchos proyectos en este ámbito se construyen pues desde ahí." (Lola, LFC)

La precariedad, el no poder afrontar el pago del alquiler del espacio, la movilidad de una de las integrantes del grupo, los cambios, las transiciones en las posiciones vitales de las compañeras (dinámicas y lógicas globalizadas, pero con consecuencias situadas) han propiciado el cierre del espacio físico de la Fábrika Crítica, pero no del proyecto. Habrá que buscar nuevas formas desde las que articularse y organizarse. Mutación es la palabra con las que Kris y Lola me hablan de este proceso. Los cuidados entre las mismas han sido fundamentales a la hora de guiar y conducir estas transformaciones:

"Creo que el cuidado en este caso sería aceptar donde estamos, aceptar muchos cambios, quizás abrir canales de comunicación para expresar bien cómo estamos, qué queremos hacer, darnos oportunidades también... Y un tema importante para mí es el compromiso, aunque suene fatal... Pero para mí es importante. Como un compromiso en tus proyectos en lo que quieres hacer, en lo político y... un compromiso que obviamente siempre van a ser dinámicos y que hay que abrir esos canales de comunicación de los que hablaba antes... Pero que los cuidados pasa mucho por entendernos, por entendernos en cada momento, respetando mucho y generar alianzas fuertes que a la vez sean dinámicas... Porque desde las posiciones en las que estamos... para mí la estaticidad de lo colectivo no... me resulta muy difícil visualizarlo... yo creo que estamos ahora en un momento muy de.... Esferalgan!" (Kris, LFC)

\section{A vueltas con lo común y el Transfeminismo}

"A mí me interesa más vivir en colectivo y generar alianzas y hacer de las vidas proyectos políticos."

(Kris, LFC)

Terminando este pasaje sobre las cuestiones a las que nos invitaban Silvia L. Gil y Amaia Pérez Orozco sobre el repensar lo común, y el darlo una centralidad, estas son las reflexiones de la Fábrika Crítica acerca de la relación entre el transfeminismo y lo común:

"No creo que el transfeminismo represente todo ni recoja todo, para mí sería un problema el pretender hacerlo. Creo que el transfeminismo se construye desde trayectorias individuales que llegan a lo común a través de las relaciones personales en un contexto super concreto y que hacen una propuesta política desde ahí... por eso, el transfeminismo tiene tantas propuestas, que van desde el postporno a la diversidad sexual, a los cuerpos, al trabajo sexual, transgénero... bueno, que permite esa articulación de cositas... se construye desde colectivos y políticas locales pero sí que en relación con lo global, en relación con la precarización, en relación con la crisis económica, en relación con la crítica a la objetividad..." (Lola, LFC) 
"Yo lo que veo que hace el transfeminismo desde mi experiencia es... ahora mismo es que está en el punto de alianzas que sí que están generando ese pensamiento. Yo creo que estamos aprendiendo a... creo que es un experimento. Creo que no es un bloque teórico o una perspectiva super clara en la cabeza, ni en la apostilla de un manifiesto... creo que es un experimento que produce cosas nuevas todo el rato. Para nosotras la Fábrika es eso. La intersección de millones de cosas que queremos tratar, que nos interesa tratar desde las alianzas que hacemos con la gente y de ver como en cada taller se producen cosas totalmente distintas. Y yo creo que esas cosas se están generando ahora. Creo que está siendo un experimento para todas en el sentido de tratar de cambiar nuestras relaciones, tratar de cambiar nuestras políticas, ver un poquito más allá, pensar nuevas maneras... O sea, tener nuevas maneras de pensar el mundo, la vida, nuestras relaciones, las acciones políticas... Creo que eso se está generando ahora. Yo creo que la respuesta es que sí. No creo que vaya a generar un pensamiento otro, creo que se generan multitudes de pensamientos otros que es lo que hay que respetar de hecho ¿no? Y creo que es lo que hay que... que es a lo que viene el transfeminismo que es a destacar la diversidad y la multiplicidad de posiciones políticas, sujetos, cuerpos..." (Kris, LFC)

Recojo para finalizar este pasaje la invitación a las alianzas que la Fábrika Crítica reclama. Son numerosas las que este proyecto ha generado durante este tiempo de luchas colectivas, compartidas, horizontales, activistas y militantes. Sería imposible abarcar en estas líneas todo lo que he aprendido con ellas, todo lo que me han aportado, todo lo que me han (de)construido, tanto dentro del espacio como fuera de él: en las manifestaciones, en las asambleas, en las jornadas, en las fiestas o a través de nuestra "política de cervezas". La última actividad realizada en este espacio de encuentro y de reflexión, fueron las jornadas de "artivismo" transfeminista realizadas el pasado mes de mayo. Fue muy emocionante el ver como nuevos proyectos cargados con contenidos críticos y subversivos están emergiendo en la ciudad y cómo el espacio de La Fábrika ha permitido este germen. Es el caso del grupo Vulbandada que nos deleitó con un interesante proyecto de postporno. La conclusión que yo saqué tanto escuchando a estas rebeldes subjetividades como a las compañeras de la Fábrika, es la de seguir trabajando en colectivo, la de seguir creando redes, apostar por la mutación y el tránsito para, desde el cuidado y tras el parón estival de nuestra ciudad, del cual ya hemos hablado, seguir tejiendo esta masa crítica que está dando forma al laboratorio transfeminista granadino, el cual tiene muchas cosas por aportar, experimentar, de(construir), pero sobretodo revolucionar.

\section{REFLEXIONES FINALES}

"Si no se puede bailar, no es mi revolución."

(Emma Goldman ${ }^{117}$ )

\footnotetext{
${ }^{117}$ Emma Goldman fue una feminista anarquista nacida en Lituania. Su trayectoria sirve de inspiración para diferentes luchas anarco feministas.
} 
Aproximarme al transfeminismo desde un lugar situado, sintiéndome, pensándome y deconstruyéndome me ha generado multitud de sensaciones. Muchas de ellas ya descritas. Otras como los dilemas no han sido muy elaboradas. El principal de ellos ha sido el de cuestionarme si tiene sentido que algo que surge y se articula en las calles, en los espacios autogestionados, en los centros sociales, penetre los muros de una institución tan rígida como es la Academia. Es explícito que he resuelto este dilema conmigo mismx puesto que estoy escribiendo este texto. He considerado políticamente interesante que estas prácticas y discursos penetren en dicha institución puesto que pueden contribuir en cierta medida a transformarla.

Esta y otras muchas cuestiones han sido reflexionadas con Manada Salvaje y con La Fábrika Crítica. Debido a la limitación de espacio no han podido aparecer todas, pero espero que ellas comprendan los límites de este trabajo que ha pretendido en todo momento nutrirse de sus voces, sus gritos y aullidos.

A lo largo de este tiempo he aprendido a entender el transfeminismo como un experimento, como un laboratorio, y he intentando recoger en estas líneas algunos de los contenidos que a través de nuestros cuerpos, nostotrxs, perras de la manada, damos vida. Como experimento, la transformación y la mutación son señas de nuestras subjetividades transfeministas. Como laboratorio, asumo que todo está en constante devenir, y que lo que yo aquí he plasmado está lleno de reflexiones e interpretaciones personales a partir de textos de otrxs teóricxs, activistas, y de relaciones políticas y afectivas con mis compañerxs. Se ha expresado con sinceridad que la pretensión de este trabajo es contribuir al cuestionamiento de una forma de producir conocimiento que descarta lo emocional, lo vivencial, lo cotidiano y que peca de heteropatriarcal y colonialista. También, comenzaba mi introducción señalando que este texto ha pretendido erigirse como híbrido, como mestizo, desestabilizando las nociones binarias con las que nuestras sociedades occidentales nos organizan, puesto que generan exclusiones, jerarquías y violencias.

Este laboratorio experimental tranfeminista que tanto me ha hecho mutar se asienta en múltiples orgías intelectuales, reflexivas y corpóreas. No están todxs, pero espero que sus prácticas y discursos se sientan reconocidos a lo largo de este escrito.

En esta orgía, hemos aprendido con Foucault que "donde hay poder hay resistencia" y que nuestra "amistad" a través de vínculos afectivos y/o sexuales no les gusta ${ }^{118}$, les asusta, porque

\footnotetext{
${ }^{118}$ Véase Foucault (1997).
} 
nuestros deseos, afectos y placeres, que no se pueden encasillar en categorías monolíticas ni esencialistas, pretenden desestabilizar su sistema capitalista y heteropatriarcal.

A través de los fluidos de Wittig, entendimos que la heterosexualidad es un régimen político y económico que nos oprime, excluye o violenta, aunque de muy diversas maneras en función de la intersección que encarnamos. También aprendimos a desidentificarnos.

Butler nos susurraba que "el sexo, por definición, siempre ha sido género" (2007, p. 57). Esto nos hizo tener los mayores orgasmos puesto que nos permite desarrollar diferentes estrategias de resistencia transformándonos, mutando, saliendo de los parámetros normativos de sexo/género/cuerpo con los que la sociedad heterocentrada nos quiere regular. Combinando estas aportaciones, aprendimos a desnaturalizar la sexualidad, el género, el sexo y el cuerpo y hemos conseguido politizarla, visibilizando diferentes opresiones e identificando varios privilegios.

Al igual que Butler, Preciado nos enseña que "en el capitalismo farmacopornográfico reinante, negar la diferencia sexual equivale a negar la encarnación de Cristo en la Edad Media”119. Pero nosotrxs, rebeldes y poco sumisxs nos atrevemos a eso y a más.

Asumiendo estas premisas, nos reapropiamos de las herramientas del amo para destruir su casa y construir las nuestras; eso lo aprendimos con De Lauretis y Haraway. Resignificamos sus tecnologías para construir manadas de perras salvajes. Aunque no tengamos mucha plata, tenemos cobre y aquí bailamos como bailan los pobres ${ }^{120}$.

Con Anzaldúa, fuimos conscientes de los cruces de fronteras que constituyen nuestras existencias. El mestizaje que encarnamos nos invita a articular luchas a partir de nuestras afinidades, de compartir objetivos y proyectos políticos comunes, porque sabemos que aunque las opresiones son diferenciales, todas están interconectadas y generadas por un sistema patriarcal, hetero, colonial y capitalista. Por eso, pretendemos que la perspectiva transfeminista sea interseccional, inclusiva e integradora.

No tenemos miedo al cruising entre nosotrxs porque ya aprendimos con Act Up, Queer Nation, La Radical Gai o LSD que detrás del sida lo que había era mucha homofobia. A través del arte denunciábamos el silencio $=a$ muerte de los gobernantes. Además con ellxs, aprendimos a

\footnotetext{
${ }^{119}$ Puede consultarse en http://paroledequeer.blogspot.com.es/2014/11/la-valentia-de-ser-uno-mismopor.html

${ }^{120}$ Parafraseando la letra de la canción El baile de los pobres de Calle13.
} 
resistir desde la cultura del sexo seguro, intentando generar relaciones sanas, seguras, consensuadas y placenteras como nos enseña La Fábrika Crítica.

Hemos construido éticas maricas, promiscuas, bolleras, mestizas, putas y trans. A través de lo que Manada Salvaje nos muestra, intentamos construir afectos, ternuras y empatías. Éticas politizadas que pretenden situar a los cuidados en una posición central en nuestras relaciones personales y experiencias políticas.

Viruta FtM nos cantaba que somos de Venus, y de Martes, y sin ser Eva ni Adán nos gusta mezclar las peras y las manzanas ${ }^{121}$ porque a veces somos una y otras veces otra; otras múltiples y diversas.

En esta orgía utilizamos nuestros cuerpos como campos de batalla, los entendemos como espacios políticos por los que pasa todo: opresiones, dominaciones, jerarquías; pero también los entendemos como lugares privilegiados para el desarrollo de nuestras estrategias de resistencias. A través ellos intentamos ser un poquito más libres (aunque ya sabemos que el poder nos constituye). Con nuestras performances, nuestros manifiestos, nuestras acciones directas, nuestro sexo salvaje, a veces en público, a veces grupal, a veces "postpornografiado", nos constituimos como terroristas y bombardeamos un sistema heteropatriarcal y capitalista que pretende regular nuestros deseos, afectos, prácticas, discursos y formas de relacionarnos con Ixs demás.

Estas orgías nos han hecho empoderarnos, ser conscientes de nuestras capacidades, habilidades y poderíos sabiendo que en manada todo es mucho más fácil, alegre y combativo. No queremos el individualismo, aunque sí que se reconozcan todas nuestras diferencias, multiplicidades, diversidades y dispersiones.

Aprendimos a politizar nuestras relaciones personales, siendo conscientes de que lo privado no es tan privado, ni lo público tan público. Ya sabemos que las dicotomías, dualismos y binarios, apestan, excluyen y jerarquizan. Queremos reventarlos. Este laboratorio experimental ha hecho que nuestras formas de estar y comprender el mundo hayan cambiado completamente.

Cuando nos fumamos el cigarro después de la orgía, pasamos interminables horas pensando en las reflexiones de Amaia Pérez Orozco y Silvia L. Gil, y además de hablar de lo bien que lo hemos pasado, conspiramos al entender que "la fortaleza política pasaría entonces por

${ }^{121}$ Canción Peras y manzanas de Viruta FtM 
recuperar juntos esa vida robada sin partir de identidades fijas que prefiguren con quiénes emprender esa tarea incierta" (Gil, 2011, p. 50).

Con Sayak Valencia identificamos a la violencia como la columna vertebral del capitalismo gore y cómo la micropolítica tiene un gran poder desestabilizador. Esta violencia se encarna en nostrxs a través de la precariedad, de la movilidad forzada. Se encarna a través de privatizaciones y de represión. En definitiva, se encarna mercantilizando nuestras vidas.

Por eso, apostamos por cuidarnos en manada. Puesto que a la mayoría de nosotras no nos interesa construir familias nucleares (ya sabemos que son radiactivas), centramos nuestro interés en cómo articular relaciones personales, sociales, políticas con nuestras compañerxs de una manera no normativa. El sistema nos enseña a relacionarnos desde la violencia. El feminismo nos enseña a relacionarnos desde los cuidados (no mitificados ni esencializados).

El transfeminismo nos hace un poquito más libres ofreciéndonos herramientas para salir de las normas heteropatriarcales impuestas como son el amor romántico, la monogamia, los celos, las dependencias, las violencias... Cuidémonos follando, riendo, bailando, cantando, abrazándonos, compartiendo miedos y temores, dudas y reflexiones, cuidémonos con locura, con pasión, con alegría, cuidémonos a lo salvaje, cuidémonos colectivamente, icuidémonos cual perras en manada! 


\section{BIBLIOGRAFÍA}

Abelove, H. (2003). From Thoreau to Queer Politics. En Deep Gossip (pp. 29-42). Minneapolis and London: University of Minnesota Press

Austin, J. L. (1962). How to do things with words. Cambridge: Harvard University Press.

Beauvoir, S. (1998). El segundo sexo. Madrid: Cátedra.

Bersani, L. (1987). Is the Rectum a Grave?. AIDS: Cultural Analysis/Cultural Activism, 43, 197222.

Brah, A. \& Phoenix, A. (2004). Ain't I A Woman? Revisiting Intersectionality. Journal of International Women's Studies, 5 (3), 75-86.

Butler, J. (1993). Introduction. En Bodies that matter: on the discursive limits of sex (pp. 1-23). New York and London: Routledge.

Butler, J. (1997). On linguistic Vulnerability. En Excitable Speech: a Politics of the Performative (pp. 1-43). New York and London: Routledge.

Butler, J. (2004). Imagination and gender insubordination. En Salih, S., Butler, J. (Eds.), The Judith Butler reader (pp. 119-137). Malden: Blackwell.

Butler, J. (2007). El género en disputa: el feminismo y la subversión de la identidad. Barcelona: Paidós.

Caserio, R. L., Edelman, L., Halberstam, J., Muñoz, J. E., \& Dean, T. (2006). The antisocial thesis in queer theory. PMLA, 819-828.

Checa Dumont, C. (2011). El placer sexual como arma política: El empoderamiento de "las mujeres" a través del placer sexual. Tesis del Máster GEMMA, Universidad de Granada.

Crenshaw, K. (1989). Demarginalizing the Intersection of Race and Sex: A Black Feminist Critique of Antidiscrimination Doctrine, Feminist Theory and Antiracist Politics. En The University of Chicago Legal Forum, 139-167.

Crimp, D. (1987). Introduction. AIDS: Cultural Analysis/Cultural Activism, 43, 3-16.

Crimp, D. (2003). The Melancholia of AIDS. Art Journal, 62 (4), 81-90.

De Lauretis, T. (2000).La tecnología del género. En Diferencias. Etapas de un camino a través del feminismo (pp. 33-69). Madrid: Horas y horas.

De Sousa Santos, B. (2010). Des-pensar para poder pensar. En Descolonizar el saber, reinventar el poder (pp. 11- 27). Montevideo: Trilce

Del Valle Murga, T. (1995). Metodología para la elaboración de la autobiografía. En Sanz Rueda, C. (coord.). Invisibilidad y presencia. Actas del seminario internacional "Género y 
trayectoria profesional del profesorado universitario". Madrid, Instituto de Investigaciones Feministas y Dirección General de la Mujer, 281-289.

Del Valle Murga, T. (2012). Un ensayo metodológico sobre la mirada en antropología social. Gazeta de Antropología, 28 (3). En http://www.gazeta-antropologia.es/wpcontent/uploads/GA-28-3-10-TeresadelVallel.pdf. Accedido el 10 de febrero de 2015.

Del Valle Murga, T. (2012). El poder evocador como desencadenante de la memoria y creatividad En Roca, J, Contreras, J., \& Pujadas, J. J. (coords.), Pels camins de I'etnografia: un homenage a Joan Prat (pp. 303-312). Tarragona: Universitat Rovira i Virgili.

Delphy, C. (1996). Rethinking sex and gender. En Leonard, D. \& Adkins, L. (Ed.), Sex in Question: French materialist feminism (pp. 30-41). London: Taylor \& Francis.

Derrida, J. (1982). Signature, Event, Context. En Limited Inc (pp. 233-252). Evanston: Northwestern University Press.

Egaña, L. (2009). La pornografía como tecnología de género. Del porno convencional al postporno. Apuntes Freestyle. En http://www.lafuga.cl/la-pornografia-comotecnologia-de-genero/273. Accedido el 16 de mayo de 2015.

Espinosa Spínola, M. (2012). "Mi banda - hogar": Resignificando la infancia a partir de los niños y niñas de la calle de la Ciudad de México. Tesis doctoral del programa de doctorado: Antropología y bienestar social, Universidad de Granada.

Esteban Galarza, M. L. (2003). Estrategias corporales masculinas y transformaciones de género. En Guasch, Ó. y Viñuales, O. (Coord.), Sexualidades: diversidad y control social (pp. 4568). Barcelona: Bellatera.

Esteban Muñoz, J. (1997). The White to Be Angry: Vaginal Davis's Terrorist Drag. Social Text 5253,15 (3-4), 80-103.

Esteban Muñoz, J. (2009). Queerness as Horizon: Utopian Hermeneutics In the Face of Gay Pragmatism. En Cruising Utopia: The Then and There of Queer Futurity (pp. 19-33). New York and London: New York University Press.

Epstein, S. (1996). A queer encounter: Sociology and the Study of Sexuality. En Steven Steidman (Ed.), Queer Theory/Sociology (pp. 145-167). Cambridge: Blackwell.

Fernández, S. y Araneta, A. (2013). Genealogías trans (feministas). En Solá, M. y Urko, E. (comp.), Transfeminismos. Epistemes, fricciones y flujos (pp. 45-71). Tafalla: Txalaparta.

Fernández de la Rota y Monter, J. A. (2012). Una etnografía de los antropólogos en EEUU: Consecuencias de los debates posmodernos. Madrid: Akal. 
Fernández Montes, M. (2010). Sujetos como objeto de estudio. En Del Olmo, M. (Ed.), Dilemas éticos en antropología. Las entretelas del trabajo de campo etnográfico (pp. $303-314$ ). Madrid: Trotta.

Ferrándiz Martín, F. J. (2011). Los métodos científico y hermenéutico en antropología e Historia de los métodos de campo y algunos ejemplos clásicos. En Etnografías contemporáneas: Anclajes métodos y claves para el futuro. Barcelona: Anthropos.

Flores Navarro, H. (2012). La desobediencia sexual en el arte postpornográfico. Lucha política feminista contra la heteronormatividad patriarcal. Tesis del Máster GEMMA, Universidad de Granada.

Foucault, M. (1987). Historia de la sexualidad. V. 1. La voluntad del saber. España: Siglo XXI.

Foucault, M. (1997). Friendship as a Way of Life. En Ethics: Subjetivity and Truth: The Essential Works of Foucault, 1954-1984, 1, 135-149.

Foucault, M. (2009). Vigilar y castigar. Nacimiento de la prisión. Madrid: Siglo XXI.

Gamson, J. (2002). ¿Deben autodestruirse los movimientos identitarios? Un extraño dilema. En Mérida Jiménez, R. (Ed.), Sexualidades transgresoras: Una antología de estudios queer (pp. 141-172). Barcelona: Icaria.

García, A. (2011). Asalto al poder en el porno. Apropiación y empoderamiento en las narraciones postpornográficas. Revista Icono, 14 (9), 361-377.

García López, C. (2013). De los No-Espacios a Los Espacios de Resistencia: Aproximación etnográfica a las arquitecturas de poder en la ciudad de Granada.

Gil, S. L. \& Orozco, A. P. (2010). Transfeminismo: ¿Sujetos o vida en común? En https://www.diagonalperiodico.net/la-plaza/transfeminismo-sujetos-o-vidacomun.html. Accedido el 28 de abril de 2015.

Gil, S. L. (2011). Nuevos feminismos: sentidos comunes en la dispersión. Una historia de trayectorias y rupturas en el Estado español. Madrid: Traficantes de sueños.

Gregrori Flor, N. (2006). Los cuerpos ficticios de la biomedicina. El proceso de construcción del género en los protocolos médicos de asignación de sexo en bebés intersexuales. AIBR. Revista de Antropología Iberoamericana, 1 (1), 103-124.

Gregorio Gil, C. (2006). Contribuciones feministas a problemas epistemológicos de la disciplina antropológica: representación y relaciones de poder. AlBR. Revista de Antropología Iberoaamericana, 1 (1), 22-39.

Gregorio Gil, C., Hernández García, J. M. \& Apaolaza, T. (2011, septiembre). Etnografiando resistencias. Simposio en el XII Congreso de Antropología: Lugares, Tiempos, Memoria. La Antropología Ibérica en el siglo XXI. León. 
Gregorio Gil, C. (2014). Traspasando las fronteras dentro-fuera: Reflexiones desde una etnografía feminista. AIBR. Revista de Antropología Iberoamericana, 9 (3), 297-322.

Guasch, Ó. (2000). La crisis de la heterosexualidad. Barcelona: Laertes.

Haraway, D. (1995). Manifiesto para cyborgs: ciencia, tecnología y feminismo socialista a finales del siglo XX y Conocimientos situados: la cuestión científica en el feminismo y el privilegio de la perspectiva parcial y (pp. 251-311 y pp. 313-346). En Ciencia, cyborgs y mujeres: la reinvención de la naturaleza. Madrid: Cátedra.

Harding, S. (1987). Introduction: Is there a feminist method?. En Harding (Ed.), Feminism and methodology (pp. 1-14). Bloomington/Indianapolis: Indiana University Press.

Hernández Rodríguez, L. M. (2014). Yo puto. Repensando el Trabajo Sexual Masculino. Tesis del Máster GEMMA, Universidad de Granada.

Hooks, B., Brah, A., Sandoval, C., Anzaldúa, G., Levins Morales, A., Bhavnani, K. K., ... \& Talpade Mohanty, C. (2004). Otras inapropiables: Feminismos desde las fronteras. Madrid: Traficantes de sueños.

Lemebel, P. (2000). Loco Afán. Crónicas de sidario. Barcelona: Anagrama.

López Penedo, S (2008). El laberinto Queer. La identidad en tiempos de neoliberalismo. Barcelona: Egales

López Penedo, S. (2012). Queer Politics in Spain: There is live after same-sex marriage legislation. Jindal Global Law Review, 4 (1), 238-263.

Lykke, N. (2011). Intersectional Analysis: Black box or Useful Critical Thinking Technology?. En Lutz, H., Herrera Vivar, M. T. \& Supik, L. (Eds.), Framing Intersectionality: Debates on a Multi-Faceted Concept in Gender Studies (pp. 207-220). London: Ashgate.

Llopis, M. (2010). El postporno era eso. Barcelona: Melusina.

Martínez Pozo, L. (2012). Cuerpos políticos feministas y el retorno de las corporalidades catalogadas como monstruosas para quebrantar la normalidad. Tesis del Máster GEMMA, Universidad de Granada.

Medeak. (2013). Violencia y transfeminismo. Una mirada situada. En Solá, M. \& Urko, E. (comp.), Transfeminismos. Epistemes, fricciones y flujos (pp. 73-79). Tafalla: Txalaparta.

Mérida Jiménez, R. (Ed.) (2009). Manifiestos gays, lesbianos y queer. Testimonios de una lucha (1969-1994). Barcelona: Icaria.

Millett, K. (2010). Política Sexual. Madrid: Cátedra.

Missé, M. \& Solá, M. (2009). La lucha trans por la despatologización, una lucha transfeminista. Conferencia de las Jornadas Feministas Estatales. Treinta años después. Aquí y ahora. Granada. 
Orozco, A. P. (2006). La economía icebergs, trabajos e (in)visibilidades. En Laboratorio Feminista, Transformaciones del trabajo desde una perspectiva feminista. Producción, reproducción, deseo, consumo (pp. 233-253). Madrid: Tierra de nadie.

Orozco, A. P. \& Lafuente, S. (2013), Economía y (trans)feminismo. Retazos de un encuentro. En Solá, M. \& Urko, E. (comp.), Transfeminismos. Epistemes, fricciones y flujos (pp. 91-108). Tafalla: Txalaparta.

Orozco, A. P. (2014). Subversión feminista de la economía. Aportes para un debate sobre el conflicto capital-vida. Madrid: Traficantes de sueños.

Platero, R. (L.). (2011). The narratives of transgender rights mobilization in Spain. Sexualities, 14 (5), 597-614.

Platero, R. (L.). (2013). Una mirada crítica sobre la sexualidad y la diversidad funcional: Aportaciones artísticas, intelectuales y activistas desde las teorías tullidas (crip) y queer. En Solá, M. \& Urko, E. (comp.), Transfeminismos. Epistemes, fricciones y flujos (pp. 211223). Tafalla: Txalaparta.

Precarias a la deriva. (2004). A la deriva por los circuitos de la precariedad femenina. Madrid: Traficantes de sueños.

Preciado, P. (B.). (2002). Manifiesto contra-sexual. Madrid: Opera Prima.

Preciado, P. (B.). (2005a). Multitudes queer. Notas para una política de los "anormales". Nombres. Revista de filosofía, 19, 157-166.

Preciado, P. (B.). (2005b). Devenir bollo-lobo o cómo hacerse un cuerpo queer a partir de El pensamiento heterosexual. En Córdoba, D., Sáez, J. \& Vidarte, P. (Eds.), Teoría Queer. Políticas bolleras, maricas, trans, mestizas. Barcelona: Egales.

Preciado, P. (B.). (2008). Testo Yonqui. Madrid: Espasa Calpe.

Preciado, P. (B). (2009a). Historia de una palabra. Parole de Queer, 1, 14-17. En https://www.scribd.com/fullscreen/79992238?access key=key-2164jancgcgodxmcd3ir. Accedido el 17 de abril de 2015.

Preciado, P. (B.). (2009b). Transfeminismo y micropolíticas del género en la era farmacopornográfica. Revista Artecontexto, 21, 58-61.

Preciado, P. (B.). (2014). La valentía de ser uno mismo. Parole de Queer. En http://paroledequeer.blogspot.com.es/2014/11/la-valentia-de-ser-uno-mismo-por.html. Accedido el 1 de mayo de 2015.

Puar, J. K. (2012). "I would rather be a cyborg than a goddess": Becoming-Intersectional in Assemblage Theory. PhiloSOPHIA, 2 (1), 49-66.

Puar, J. K. (2005). Queer times, queer assemblages. Social Text 84-85, 23(3-4), 121-139. 
Rich, A. (1980). Compulsory Heterosexuality and Lesbian Existence. Signs: Journal of Women in Culture and Society, 5 (4), 631-660.

Sáez, J. (2005). El contexto sociopolítico de surgimiento de la teoría queer. De la crisis del sida a Foucault. En Córdoba, D., Sáez, J. y Vidarte, P. (Eds.), Teoría Queer. Políticas bolleras, maricas, trans, mestizas (pp. 67-76). Barcelona: Egales.

Solá, M. (2012). La re-politización del feminismo, activismo y microdiscursos posidentitarios. Desacuerdos. Sobre arte, políticas y esfera pública en el Estado español, 7, 264-281.

Solá, M. (2013). Introducción: Pre-textos, con-textos y textos. En Solá, M. \& Urko, E. (comp.), Transfeminismos. Epistemes, fricciones y flujos (pp. 15-27). Tafalla: Txalaparta.

Spargo, T. (2004). Foucault y la teoría queer. Barcelona: Gedisa.

Torres, D. J. (2011). Pornoterrorismo. País Vasco: Txalaparta.

Trujillo, G. (2005). Desde los márgenes. Prácticas y representaciones de los grupos queer en el Estado español. En Romero Bachiller, C., García Dauder, S. \& Bargueiras Martínez, C. (Eds.), El eje del mal es heterosexual. Figuraciones, movimientos y prácticas feministas queer (pp. 29-44). Madrid: Traficantes de sueños.

Valencia, S. (2010). Capitalismo Gore. España: Melusina

Valencia, S. (2013). Transfeminismo(s) y capitalismo gore. En Solá, M. \& Urko, E. (comp.), Transfeminismos. Epistemes, fricciones y flujos (pp. 91-108). Tafalla: Txalaparta.

Vendrell Ferré, J. (2003). Del cuerpo sin atributos al sujeto sexual: sobre la construcción social de los seres sexuales. En Guasch, Ó. y Viñuales, O. (Coord.), Sexualidades: diversidad y control social (pp.21-43). Barcelona: Bellatera.

Vidarte, P. (2005). El banquete uniqueersitario: disquisiciones sobre el s(ab)er queer. En Córdoba, D., Sáez, J. \& Vidarte, P. (Eds.), Teoría Queer. Políticas bolleras, maricas, trans, mestizas (pp. 67-77). Barcelona: Egales.

Warner, M. (Ed.). (1993). Fear of a Queer Planet: Queer Politics and Social Theory. Minneapolis and London: University of Minnesota Press.

Weiss, M. (2008). Gay Shame and BDSM Pride: Neoliberalism, Privacy, and Sexual Politics. Radical History Review, 100, 87-101.

Wekker, G. (2006). The Politics of Passion: Women's Sexual Culture in the Afro-Surinamese Diaspora. New York: Columbia University Press.

Wittig, M. (1992). The Category of Sex, One is Not Born a Woman y The Straight Mind. En The Straight Mind and Other Essays (pp. 1-32). Boston: Beacon Press.

Ziga, I. (2009). Devenir perra. España: Melusina. 
Ziga, I. (2013). ¿El corto verano del transfeminismo?. En Solá, M. \& Urko, E. (comp.), Transfeminismos. Epistemes, fricciones y flujos (pp. 81-87). Tafalla: Txalaparta.

\section{PÁGINAS WEB Y BLOGS CONSULTADOS}

http://trafikantedecolores.webnode.es/otrascreaciones/haz-el-amor-y-tambien-la-guerra/ http://nadaquerascar.webnode.es/provectos/monstruos/

http://www.pikaramagazine.com

http://lafabrikacritica.com/

https://eskandalopubico.wordpress.com/

http://www.lucysombra.org/archives/category/pornologia/mi-sexualidad-es-una-creacionartistica

http://postop-postporno.tumblr.com

https://otraeskuelitadefoto.wordpress.com/

http://quimerarosa.net/

http://www.ideadestroyingmuros.info/

http://granada.cnt.es/

https://distribuidorapeligrosidadsocial.wordpress.com/

http://www.yeswefuck.org/

http://migrantestransgresorxs.blogspot.com.es/p/quienes-somos.html

http://pornoterrorismo.com/

http://www.vaginaldavis.com/

http://www.lafuga.cl

https://www.diagonalperiodico.net

http://anarchagland.hotglue.me/

http://anarchagland.tumblr.com/ 
http://paroledequeer.blogspot.com.es

http://medeak.blogspot.com.es/

http://lacentrifugadora.org/

http://www.hartza.com/

\section{VÍDEOS CONSULTADOS}

Jo Sol. (Director). (2009). Fake Orgasm. [Documental]. España. http://vk.com/video ext.php?oid=108221761\&id=159345196\&hash=2e16478f7698a3e $3 \& h d=1$

Marano, F. P. (Directora). (2009). Test de la vida real. [Documental]. España. https://www.youtube.com/watch?v=yrgrZOR -3U

Revista Postporno Pirate. (2013). [Documental]. España. http://www.dailymotion.com/video/xybvun revista-piratte creation?start=38

Preciado, P. (B). (2013). ¿La muerte de la Clínica?. https://www.youtube.com/watch?v=4aRrZZbFmBs

Preciado, P. (B). (2014). Las subjetividades como ficciones políticas. Hay festival, Cartagena. https://www.youtube.com/watch?v=R4GnRZ7 -w4

Preciado, P. (B). (2015). La revolución que viene: Luchas y alianzas somatopolíticas. Malba, Argentina. https://www.youtube.com/watch?v=vsV2e FBreA

Entrevista a Preciado por Alejandro Jodorowsky. https://www.youtube.com/watch?v=M4k98oLXAml

Entrevista a Sayak Valencia en Luchadoras. Rompeviento TV. (20/06/2012). https://www.youtube.com/watch?v=tigb-2Ryx24

Entrevista a Diana J. Torres en Luchadoras. Rompeviento TV. (08/05/2013). https://www.youtube.com/watch?v=IUhhJDavMss 


\section{ANEXO № 1.}

\section{LAS PERRAS MARCELINAS (Manifiesto en tránsito)}

Somos un colectivo en construcción y movimiento que brota de la experiencia de la Asamblea Identidades en Tránsito. Dicha asamblea ha sido un experimento colectivo de diálogo entre diferentes realidades feministas, que nace conectado con el programa y el espacio académico del Máster GEMMA. La gente que lo componía, desde su diversidad epistemológica y prácticopolítica, está ahora transitado a diferentes lugares. Para nosotrxs, en este momento, el lugar al que queremos pertenecer es este: LAS PERRAS MARCELINAS, espacio que aúna nuestras posiciones queer y transfeministas.

Debemos dejar claro que tres de Las Perras Marcelinas estamos aquí de paso, estamos en tránsito hacia otras ciudades, y ese límite temporal de cinco meses marca los objetivos y las formas políticas que podemos activar en el territorio de Granada en el futuro próximo. No obstante, pretendemos tejer lazos y redes que perduren en el tiempo a pesar de nuestra posición esquizofrénica de movilidad posmoderna, con el objetivo de activar formas de resistencia y lucha queer-transfeministas transnacionales. Nos posicionamos también desde la subalternidad conectada con la intersección entre juventud socio-económica (precariedad económica y afectiva y sujeción política) y subjetividad sexual disidente. Dicha subalternidad nos vulnerabiliza de una manera específica, y así queremos dar vida a una lucha común y compartida entre los sujetos feminizados/desposeídos.

Debido a los límites temporales que condicionan inevitablemente nuestros objetivos, formas y estrategias políticas, nuestra posibilidad de acción y resistencia política en el territorio de la ciudad de Granada nos hemos constituido con el objetivo específico de generar y promover un espacio concreto TRANS en Granada, además de la interacción/colaboración con otras redes queer y transfeministas de la ciudad, así como la presencia en las movilizaciones y acciones en contra de la Ley Gallardón y otras leyes represivas estatales y transnacionales (ley de seguridad ciudadana, RD 1/16 de 2012 sobre reforma sanitaria). Nos mostramos disponibles para la construcción de cualquier acción que contribuya a la resistencia queer y de políticas transfeministas.

Nuestras líneas ideológicas-analíticas y que guían nuestras acciones/objetivos políticos particulares giran en torno a los siguientes ejes:

1. AFECTIVIDAD Y SEXUALIDAD: las estrategias y las alianzas que nos gustaría desplegar tienen que ver con la crítica/desnaturalización de las tecnologías dominantes, heteropatriarcales y capitalistas de organización de los afectos y las sexualidades, y a la vez la experimentación/laboratorio de narrativas contrahegemónicas. Tratamos de producir espacios discursivos de resistencia social.

2. CUIDADOS, PRODUCCIÓN Y REPRODUCCIÓN: enganchamos el cuestionamiento de la ordenación heteronormativa de los individuos con la reproducción de los órdenes de desigualdad política y económica global. Frente a la lógica individualista e imperialista según la 
que se organiza la economía política y la existencia proponemos modelos comunitaristas y ausentes de jerarquías de género de organización de la reproducción social y la producción económica. Apostamos por una nueva ética de los cuidados que destruya las fronteras entre la esfera pública y privada y la consiguiente plusvalía masculinista que generan las tareas reproductivas, feminizadas, no remuneradas e invisivilizadas de cuidados en las cuales se sustenta el sistema para su continuidad.

3. APROPIACIÓN DE LA AUTORIDAD COLECTIVA: nos alzamos en contra de la represión social y violencia política puestas en marcha por las maquinarias interestatales como la otra cara del proceso de desposesión generalizada en el contexto actual del capitalismo. El autoritarismo político y económico practicado por los estados es causa directa de la precarización de la vida, la feminización de la pobreza y de la supervivencia, la feminización de las subjetividades marginales, el ataque a los derechos sexuales y reproductivos, la destrucción de las vidas migrantes, la exclusión de las personas diversas funcionales. Denunciamos la violencia exacerbada sobre la cual se apoya, se sostiene, se configura el actual sistema capitalista heteronormativo que nos vuelve vulnerables. Pero nos alzamos no como víctimas, sino como sujetxs con agencia, con capacidad de disidencia.

4. EL CUERPO COMO ESPACIO DE RESISTENCIA SUBJETIVA. Entendemos que en el proceso de desposesión capitalista de nuestras vidas, el cuerpo se ha colocado en los márgenes del sistema. Pretendemos otorgarle a la vida y al cuerpo la centralidad necesaria para enfrentarnos a la precariedad diferencial que atraviesa nuestras vulnerabilidades. La necesidad de expulsar a los mercados y al capital del lugar privilegiado que ocupan se presenta como primordial en el nuevo orden social que pretendemos construir colectivamente. Esto implica el rechazo a las categorías esencialistas y dicotómicas que jerarquizan y constriñen nuestras libertades, deseos, prácticas o formas de relacionarnos con Ixs demás. Cuestionamos la naturalidad de los cuerpos, de los sexos, de los géneros y conceptualizamos a los mismos como plásticos, moldeables, corrompibles, inestables, en un continuo proceso de tránsito, sin destino fijo ni fin. Es ahí donde reside la potencialidad de nuestras micropolíticas de resistencia al heteropratriarcado. Pretendemos dinamitar el sistema sexo/género que oprime nuestras vidas para crear redes libres de interacción entre las personas.

Nosotrxs, desobedientes del género, disidentes sexuales, rechazamos la heterosexualidad obligatoria, garante del poder y del orden social establecido que criminaliza a aquellas sexualidades no ortodoxas, las identifica como ANOrmales al alejarse de su dogma. Las Perras Marcelinas nos corremos en la biología, damos por el culo a los genes, hacemos un fisting a la norma (invitamos a norma); ahora nos satisface la definición de monstruos, de desviadas, de perversas... la batalla no ha hecho más que empezar. Nosotrxs devenimos QUEER, devenimos PERRAS. 


\section{ANEXO №2}

\section{MANIFIESTO PÚBICO (ESKÁNDALO PÚBICO)}

Perras, marimachos, bolleras, tortilleras, intersexuales, transmaricas, transgéneros, travelos, osos, hombres con coño y mujeres con pene, zorras, locxs, precariaxs, descolocadxs, tullidas, heteros con pluma.....todo tipo de fauna granaína o de paso por Graná, que deseamos de una vez por todas encontrarnos para empezar a articularnos. Un encuentro donde cuestionarnos el lugar donde vivimos, cómo lo vivimos y qué queremos hacer.

Habitamos estos cuerpos mutados, placenteros, rapados, marcados, peludos, promiscuos... Desde sexualidades, trayectorias y formas de hacerlo juntxs que tensionan, desordenan y dinamitan. Dispuestxs a politizar hasta el último rincón de nuestras normalizadas existencias, hace tiempo que empezamos a rechazar privilegios, a ubicarnos en marginalidades geopolíticas, a hacer ruido, a buscarnos y enredarnos entre nosotrxs.

Desde nuestras disidencias queremos pervertir el sistema, que nos vean, que se enteren que aquí damos caña. Nos proponemos provocar la chispa que queme categorías rígidas e impuestas, relaciones de poder, discursos hegemónicos; todo ello empezando por nosotrxs mismxs. Un espacio donde queremos volcar nuestra malafollá aunque sabemos de sobra que follamos muy bien. Donde queremos visibilizar que somos unas prendas y donde poder responder de una vez a la pregunta ¿qué pollas haces? Y decir "lo que nos sale del coño". Hacer ver que somos unas lacias, unas siesas y unas cafres. Un espacio para dinamitar a los grupos granaínos de machirulos y machistas empederníos, con sus bromas y agresiones varias llamándose entre ellos compae, y decirles que las comaes vienen con mucha metralla por repartir. Queremos gritar con todas nuestras ganas "que vamos de bar en peor"!!!

Cervezas y demás sustancias calificadas como perjudiciales, excesos, fanzines, talleres, blogs, prótesis,... ya se han convertido en constantes y desde aquí impulsamos este proyecto. Desde feminismos callejeros, políticas queer y ganas de estar en contra que contemplan la autoedición y el diseño como formas de activismo.

Un espacio contracultural, autogestionado y libre, que emerge de un sentir de distintos activismos, herederos de determinados feminismos, que beben de las micropolíticas queer, las luchas postcoloniales y la politización transmaricabollo y transfeminista, con ganas de traer debates, cuestiones y proyectos que generan conflictos incluso dentro de los feminismos hegemónicos actuales y las vertientes más normalizadoras de los movimientos LGTB, aquellos aspectos que incomodan, que tensionan...

No pretendemos convencer a nadie si no generar un espacio compartido. Nos interesan aquellas producciones que desestabilicen el sistema sexo, género y sexualidad, que transiten, enreden y dinamiten categorías. Que desplacen las fronteras de lo cotidiano, los limites corporales, sexuales y espaciales, generando rupturas, activismos cotidianos y locales, formas de estar juntxs, visibilizando sin representatividades, produciendo corporalidades y subjetividades do it yourself and do it with others, y devenir lo que te dé la gana.

Desde el amor que Ixs perrxs lúbricxs sabemos darnos, estamos deseando compartir luchas y buscar formas más bonitas de querernos, de romper barreras, de relacionarnos y de tender 
puentes hacia espacios más libres. Pretendemos generar nuevas condiciones políticas y artísticas, que hagan de las sexualidades, los cuerpos y las calles campos de batalla.

\section{ANEXO № 3.}

\section{MANIFIESTO PIGS (Traducción)}

¿Por qué nos percibimos como sujetxs interseccionales?

Con el objetivo de evitar lo máximo posible la creación de un "otro" y tomar conciencia sobre la cuestión de la "otredad", nos gustaría hablar en este vídeo sobre por qué nos percibimos nosotrxs como sujetx interseccionales. Siguiendo a Haraway, nos gustaría situarnos a nosotrxs mismxs y de esta forma, tenemos que reconocer nuestros privilegios con el objetivo de posibilitar la solidaridad feminista entre aquellxs quienes están en los márgenes del sistema. En primer lugar, sabemos que somos gente blanca y nuestra blancura nos proporciona varios privilegios posicionándonos en un lugar privilegiado en la jerarquía geopolítica. También reconocemos que estamos hablando desde la Academia, el lugar más privilegiado para la producción de conocimiento.

Pero asumiendo la cuestión de la reflexividad en nuestro trabajo, nos gustaría hablar sobre nuestras experiencias y sentimientos en diferentes instituciones y así decir que nos percibimos como subjetividades interseccionales porque estamos constituidxs por diferentes regímenes de opresión que vivimos en nuestras prácticas diarias, aunque también encontramos lugar para la resistencia. Nos gustaría aplicar la perspectiva interseccional desde nuestras afinidades, no desde fijas y estables identidades.

Siguiendo a Lykke, entendemos la interseccionalidad como una forma de pensamiento, una tecnología de pensamiento que nos ayuda a "repensar como diferencias de poder, normalidades y formaciones identitarias en términos de género, raza, clase, sexualidad" (2012, p. 27), diversidad funcional, lenguaje, etc. son mutuamente construidas en un proceso de coproducción y mutua transformación.

Estudiando en una Universidad con un sistema americano de educación, hemos percibido nuestra vulnerabilidad en diferentes formas. La barrera lingüística nos conduce a entenderla como otro de los mecanismos (además del hate speech, injuria) que posibilita nuestra vulnerabilidad dentro del lenguaje.

Esta vulnerabilidad está también conectada con nuestra posición geopolítica como sujetxs del sur de Europa. Claro ejemplo de esto, es el acrónimo P.I.G.S, más bien, insulto que los países hegemónicos de la Unión Económica Europea utilizan para describir a los países europeos (Portugal, Italia, Grecia y España) más afectados por la crisis financiera del 2008. La precariedad que constituye nuestras existencias está muy relacionada a las políticas de austeridad implementadas por la TROIKA, es decir, La comisión europea, El banco central europeo y El fondo monetario internacional. Los países PIGS son considerados improductivos para los grandes intereses financieros pero aun así, lugares para explotar y lugares donde extraer recursos territoriales y humanos. Su nuevo eslogan de flexibilidad es simplemente una forma para incrementar la explotación, haciéndonos más vulnerables y sujetadxs a través de 
diferentes chantajes. Estas políticas neoliberales nos fuerzan a emigrar desde nuestros países a los países hegemónicos para ser explotados y vendernos como mano de obra cualificada ocupando trabajos precarios. Así, el sistema capitalista desposé nuestras existencias de diferentes formas forzándonos, normalizándonos a sus tiempos y lugares productivos.

Como disidentes sexuales, nuestra vulnerabilidad se incremente en este sistema debido a que, como señala Michael Warner "toda persona quien se autodenomina como queer sabe de una forma u otra que su estigmatización está conectada al género, a la familia, a las nociones de libertad individual, al estado, al discurso público, al consumo y deseo, a la naturaleza y a la cultura, madurez, a las políticas reproductivas, a la fantasía racial y nacional, a la identidad de clase, a la verdad y a la confianza, a la censura, a la vida íntima y la exhibición social, al terror y a la violencia, al sistema de salud, y a las profundas normas culturales que constituyen el cuerpo" (1993, p. 13). Así, nuestras luchas no pueden centrarse sólo en un eje de opresión. Tenemos que luchar contra todas estas cuestiones al mismo tiempo, localmente pero en una red transnacional de abyectos asumiendo las consecuencias.

Entendemos que en el proceso capitalista de desposesión de nuestras vidas, el cuerpo ha sido colocado en los márgenes del sistema. Reclamamos otorgarle a la vida en general y al cuerpo en particular, la necesaria centralidad para superar la vulnerabilidad que cruza nuestras subjetividades. Entendemos nuestros cuerpos como depositarios de las acciones sociales, de la represión social y de la violencia política, pero también los entendemos como lugares de resistencia.

Nos gustaría utilizar este MANIFIESTO PIGS con el objetivo de resistir y visibilizar estas opresiones señalando que:

1) Entendemos la interseccionalidad como una forma de pensamiento, una forma de teorización y una forma de acción política.

2) Rechazamos las categorías esencialistas y dicotómicas que organizan la vida social

3) No sólo somos víctimas, sino sujetxs con agencia y con capacidad de disidencia.

4) Denunciamos la violencia exacerbada sobre la que el heteropatriarcado y capitalismos descansan y nos vulnerabilizan.

5) Apostamos por acciones y redes horizontales y rizomáticas reconociendo nuestras genealogías feministas.

6) Entendemos nuestros cuerpos como lugares privilegiados para desarrollar micropolíticas subversivas. Lejos de acciones políticamente correctas, nuestras armas son dildos, látigos, libros, asambleas, performances, parodias, manifestaciones y acciones colectivas.

7) Utilizamos la resignificación de los insultos (PIGS y QUEER) para describir nuestro posicionamiento crítico ante el heteropatriarcado y el capitalismo.

8) Asumiendo la solidaridad feminista, reclamamos alianzas y coaliciones entre los abyectos del sistema, no desde fijas identidades sino desde nuestras afinidades. 
¡Por todxs nuestrxs camaradas, compañerxs, LA REVOLUCIÓN SERÁ PIGS TRANSFEMINISTA o no será!

\section{ANEXO № 4. \\ MANIFIESTO PARA LA INSURRECCIÓN TRANSFEMINISTA}

Hacemos un llamamiento a la insurrección TransFeminista:

Venimos del feminismo radical, somos las bolleras, las putas, Ixs trans, las inmigrantes, las negras, las heterodisidentes... somos la rabia de la revolución feminista, y queremos enseñar los dientes; salir de los despachos del género y de las políticas correctas, y que nuestro deseo nos guíe siendo políticamente incorrectas, molestando, repensando y resignificando nuestras mutaciones. Ya no nos vale con ser sólo mujeres. El sujeto político del feminismo "mujeres" se nos ha quedado pequeño, es excluyente por sí mismo, se deja fuera a las bolleras, a Ixs trans, a las putas, a las del velo, a las que ganan poco y no van a la uni, a las que gritan, a las sin papeles, a la marikas...

Dinamitemos el binomio género y sexo como práctica política. Sigamos el camino que empezamos, "no se nace mujer, se llega a serlo", continuemos desenmascarando las estructuras de poder, la división y jerarquización. Si no aprendemos que la diferencia hombre mujer, es una producción cultural, al igual que lo es la estructura jerárquica que nos oprime, reforzaremos la estructura que nos tiraniza: las fronteras hombre/mujer. Todas las personas producimos genero, produzcamos libertad. Argumentemos con infinitos géneros...

Llamamos a la reinvención desde el deseo, a la lucha con nuestros cuerpos ante cualquier régimen totalitario. iNuestros cuerpos son nuestros!, al igual que lo son sus límites, mutaciones, colores, y transacciones. No necesitamos protección sobre las decisiones que tomamos en nuestros cuerpos, transmutamos de género, somos lo que nos apetece, travestis, bollos, superfem, buch, putas, trans, llevamos velo y hablamos wolof; somos red: manada furiosa.

Llamamos a la insurrección, a la ocupación de las calles, a los blogs, a la desobediencia, a no pedir permiso, a generar alianzas y estructuras propias: no nos defendamos, ihagamos que nos teman!

Somos una realidad, operamos en diferentes ciudades y contextos, estamos conectadxs, tenemos objetivos comunes y ya no nos calláis. El feminismo será transfronterizo, transformador transgenero o no será, el feminismo será TransFeminista o no será...

Os Keremos.

Red PutaBolloNegraTransFeminista.

Medeak, Garaipen, La Acera Del Frente, Itziar Ziga, Lolito Power, Las Chulazas, Diana J. Torres AKA Pornoterrorista, Parole de Queer, Post_op, Las maribolheras precarias, Miguel Misse, Beatriz Preciado, Katalli, MDM, Coletivo TransGaliza, Laura Bugalho, EHGAM,NacionScratchs, IdeaDestroyingMuros, Sayak Valencia, TransFusión, Stonewall, Astrid Suess, Alira Araneta Zinkunegi, Juana Ramos, 7menos20, Kim Pérez (Cofundadora de Conjuntos Difusos), d-generadas, las del 8 y et al, Beatriz Espejo, Xarxa d'Acció Trans-Intersex de Barcelona, Guerrilla Travolaka, Towanda,Ciclobollos, O.R.G.I.A, Panteras Rosas, Trans Tornados,Bizigay, Pol Galofre, No Te Prives, CGB, Juanita Márkez Quimera Rosa, Miriam Solà, Ningún Lugar, Generatech, Sr. y Sñra. Woolman, Marianissima Airlines,As dúas, Oquenossaedacona, Go Fist 
Foundation, Heroína de lo periférico, Lola Clavo, Panaderas Sin Moldes, Señorita Griffin, Impacto Nipón, Las Mozas de KNY, Kabaret Lliure de Mediona, Teresa Matilla, ItuEnAcción, Rodrigo Requena, Alba Pons

Rabassa, Mery Escala,Panaderas Sin Moldes, Señorita Griffin, Impacto Nipón, Las Mozas de KNY, Kabaret Lliure de Mediona, Teresa Matilla, Proyecto Transgénero Cuerpos Distintos, Derechos Iguales, Casa Trans de Quito, TransTango, Patrulla Legal, Confederación Ecuatoriana de Comunidades Trans e Intersex

\section{ANEXO № 5.}

\section{CONTRAFACTA “BOLLERA MARCELINA, TRAVESTI NICOLÁS”}

Colás, Colás, travesti Nicolás,

lo mucho que te quiero y el mal pago que me das.

Si quieres, no puedes, mejor me voy a bailar,

entre una copa y otra me ligo yo a la Paz.

Bollera Marcelina ¿dónde estás que no te veo?

Estoy aquí en la tina jugando con el dedo.

Bollera Marcelina ¿dónde estás que no te veo?

Estoy aquí en la tina jugando con el dedo.

Colás, Colás, travesti Nicolás,

lo mucho que te quiero y el mal pago que me das.

Si quieres, no puedes, mejor me voy a bailar,

entre una copa y otra me ligo yo a la Paz.

Bollera Marcelina ven dime dónde estás.

Estoy aquí con lo Mina comiendo lo de atrás.

Bollera Marcelina ven dime dónde estás.

Estoy aquí con la Mina comiendo lo de atrás.

Colás, Colás, travesti Nicolás,

Lo mucho que te quiero y el mal pago que me das.

Si quieres, no puedes, mejor me voy a bailar,

entre una copa y otra me ligo yo a la Paz.

Bollera Marcelina, yo ya no puedo más,

yo ya me voy pa' casa, tú fóllate a la Paz. 
Bollera Marcelina, yo ya no puedo más,

yo ya me voy pa' casa, tu fóllate a la Paz.

Colás, Colás, travesti Nicolás,

Lo mucho que te quiero y el mal pago que me das.

Si quieres, no puedes, mejor me voy a bailar,

entre una copa y otra me ligo yo a la Paz. 
ANEXO №6.

\section{FOTOS DE LAS PERRAS MARCELINAS}

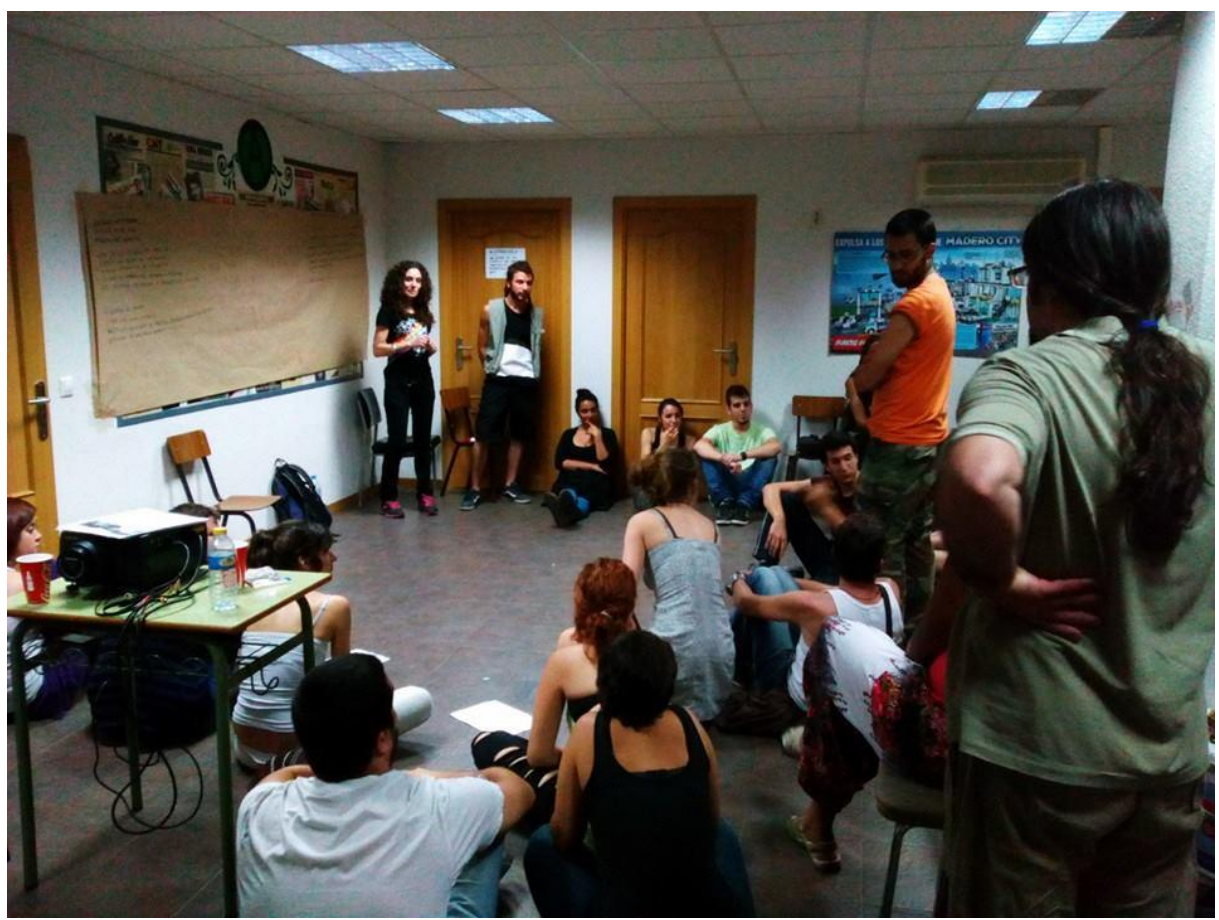

Foto no1: Taller "Mi cuerpo, mi vida, mi forma de follar: estrategias para la autodeterminación sexual y afectiva" (CNT, Mayo 2014)

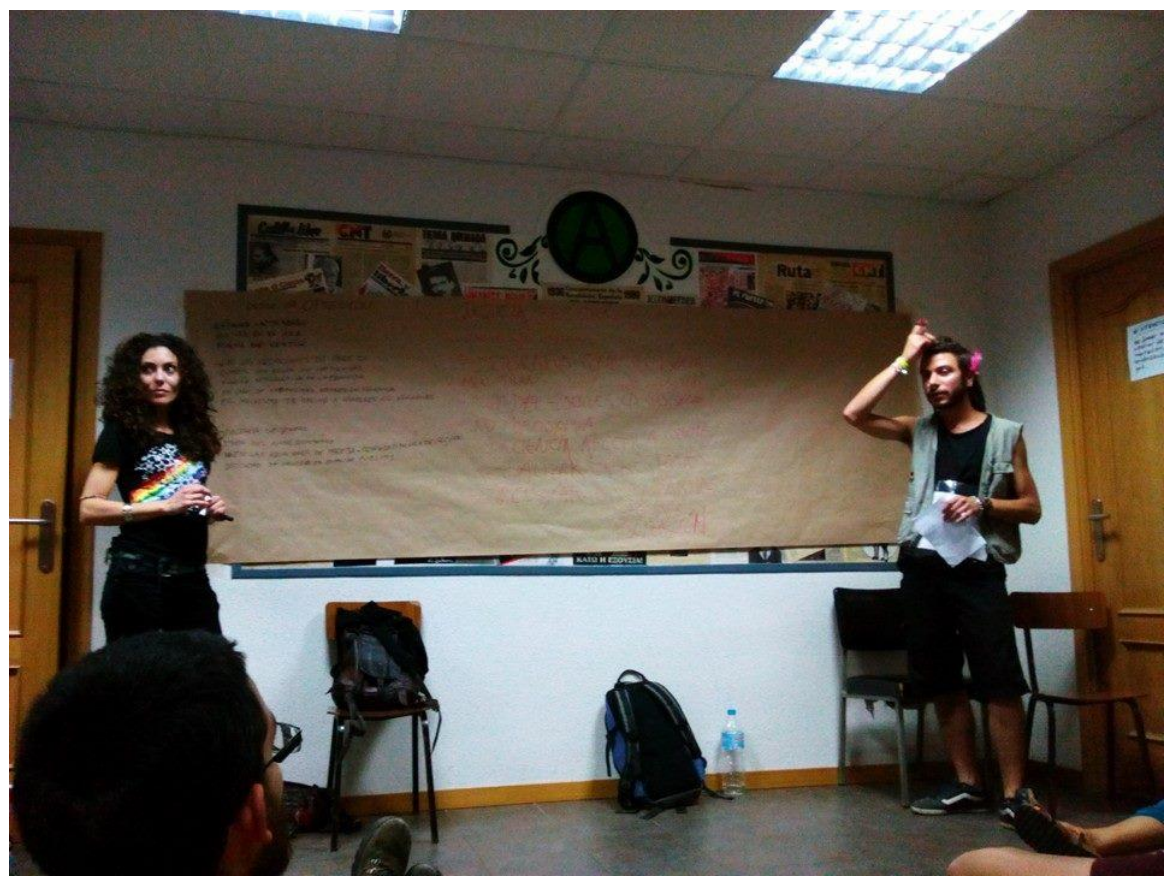

Foto no 2: Taller "Mi cuerpo, mi vida, mi forma de follar: estrategias para la autodeterminación sexual y afectiva" (CNT, Mayo 2014) 


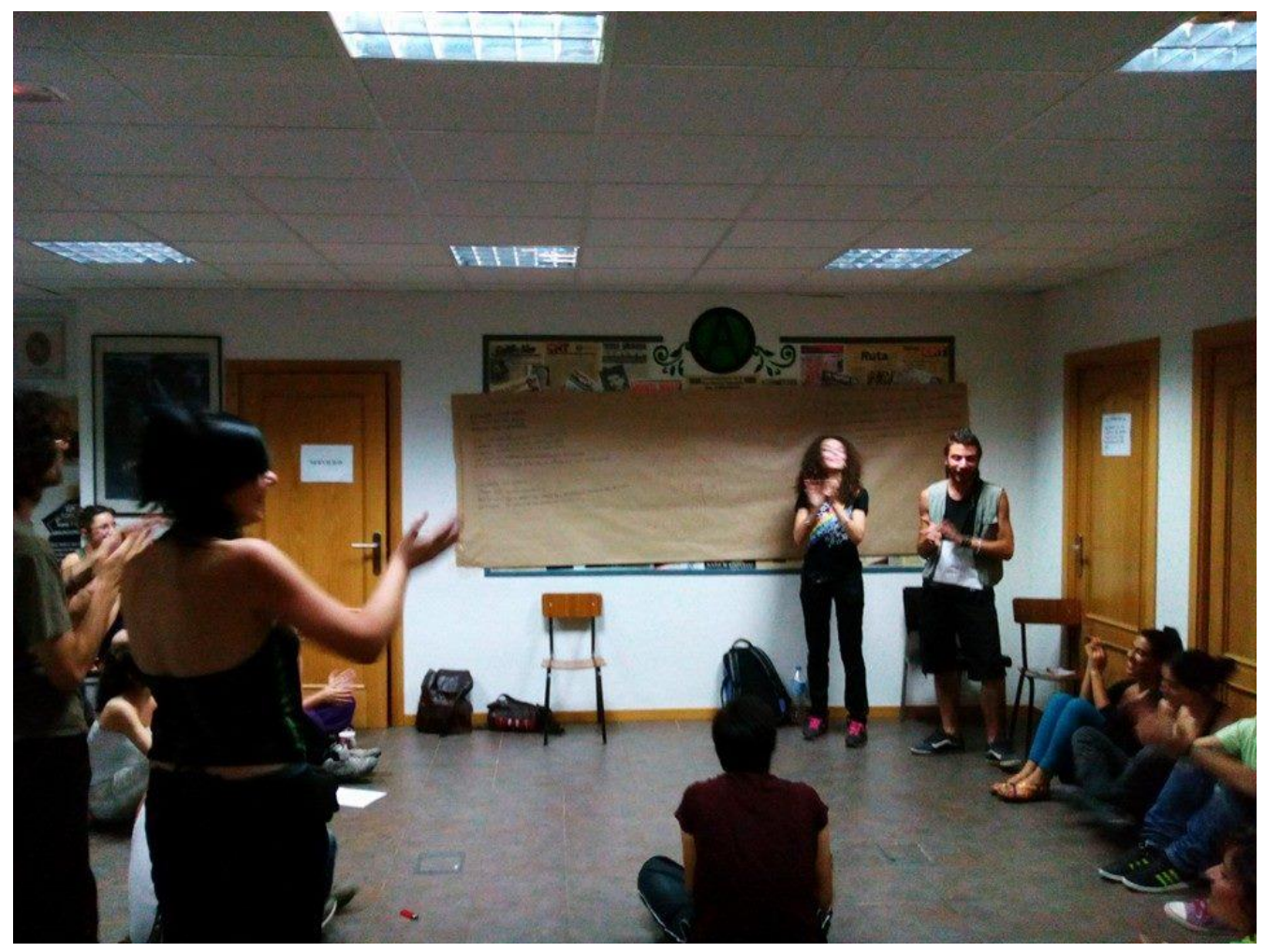

Foto no 3: Taller "Mi cuerpo, mi vida, mi forma de follar: estrategias para la autodeterminación sexual y afectiva" (CNT, Mayo 2014)

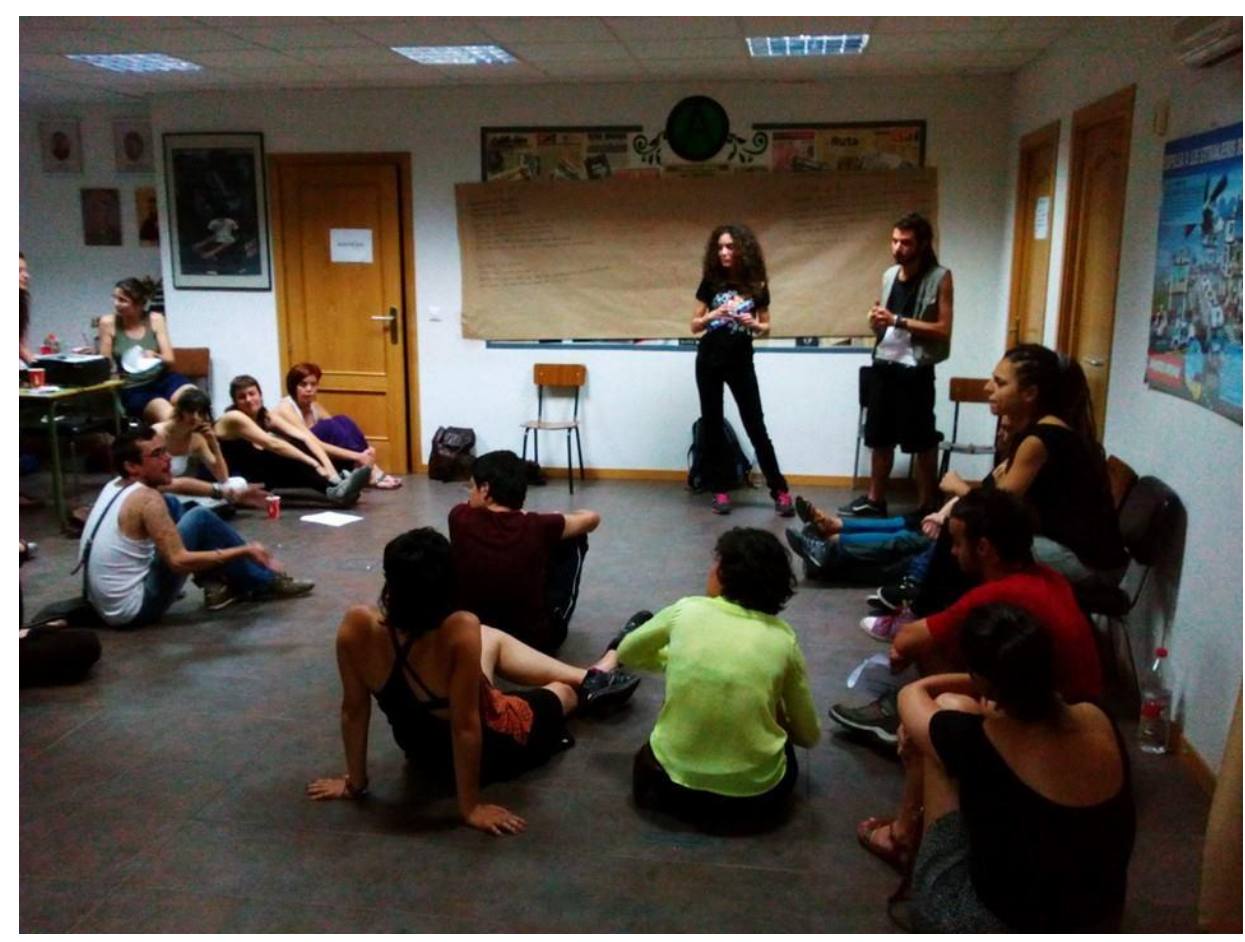

Foto $\mathrm{n}$ - 4: Taller "Mi cuerpo, mi vida, mi forma de follar, estrategias para la autodeterminación sexual y afectiva" (CNT, Mayo 2014) 


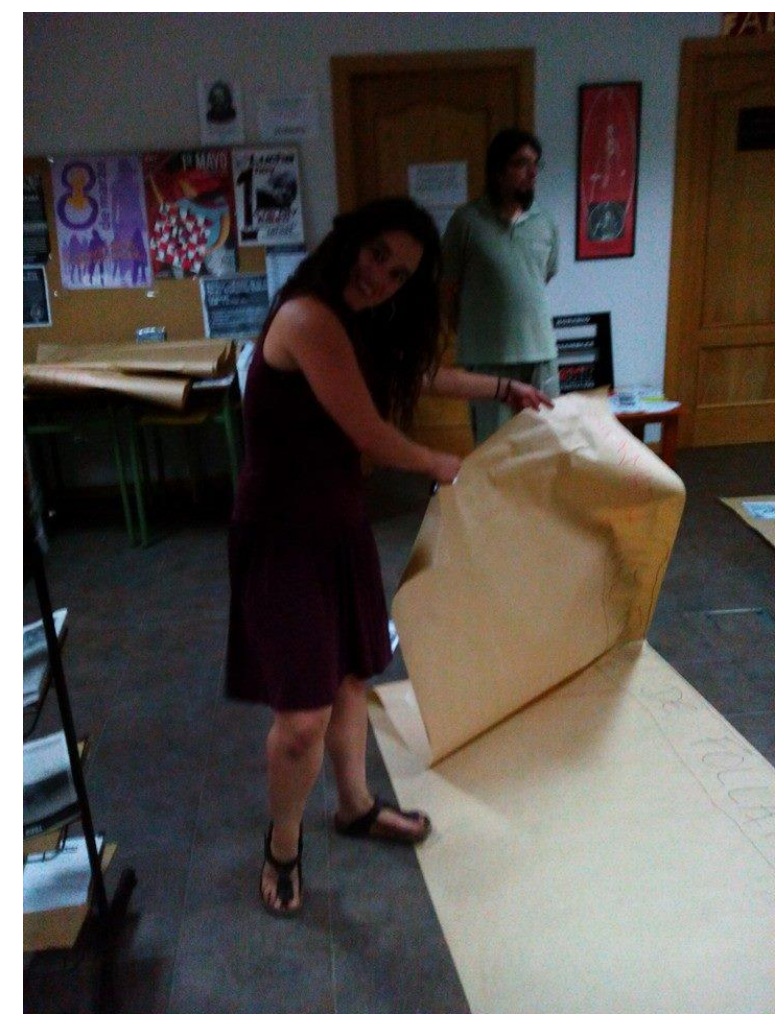

Foto nำ 5: Taller “Mi cuerpo, mi vida, mi forma de follar: estrategias para la autodeterminación sexual y afectiva" (CNT, Mayo 2014)

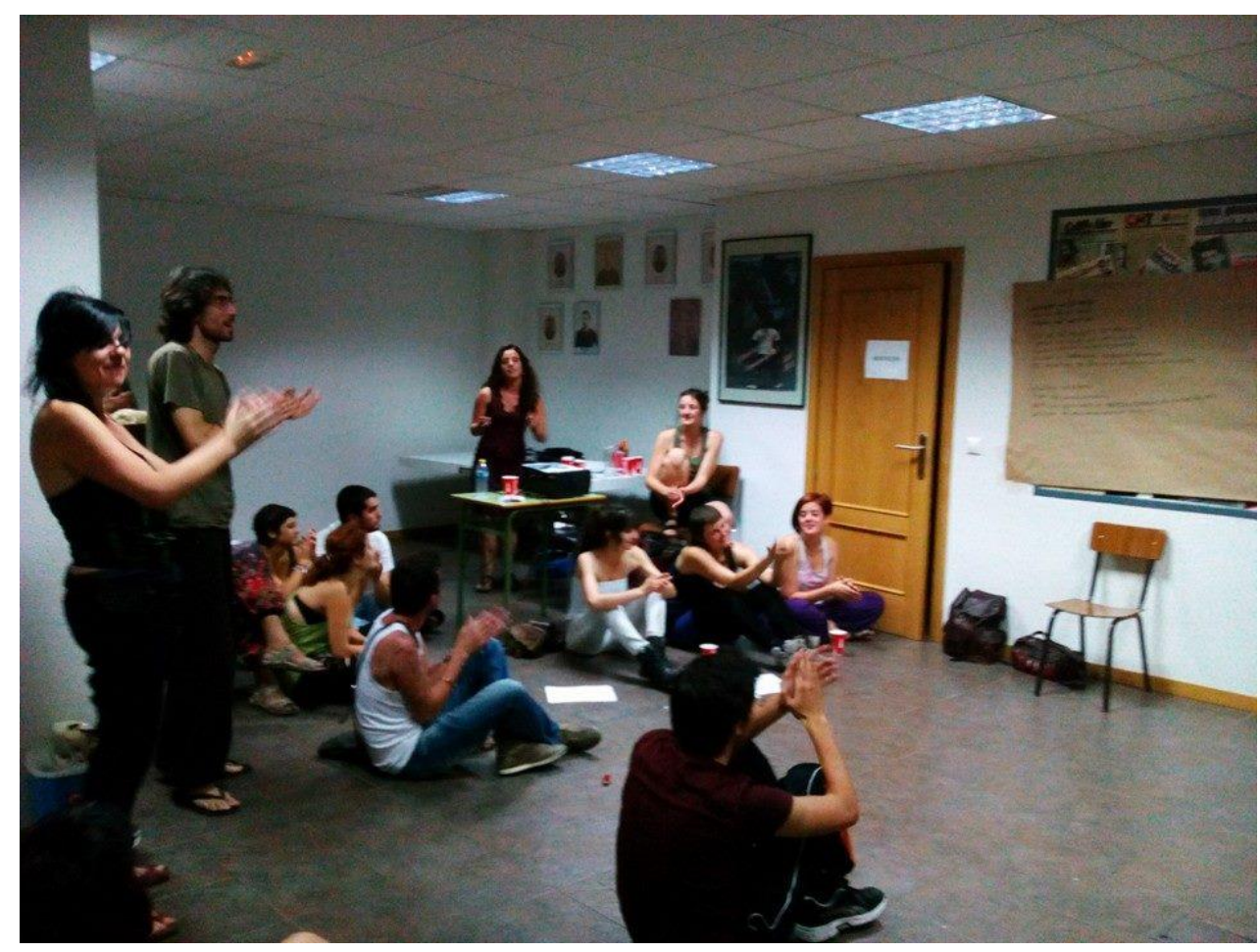

Foto n 6: Taller “Mi cuerpo, mi vida, mi forma de follar: estrategias para la autodeterminación sexual y afectiva" (CNT, Mayo 2014) 


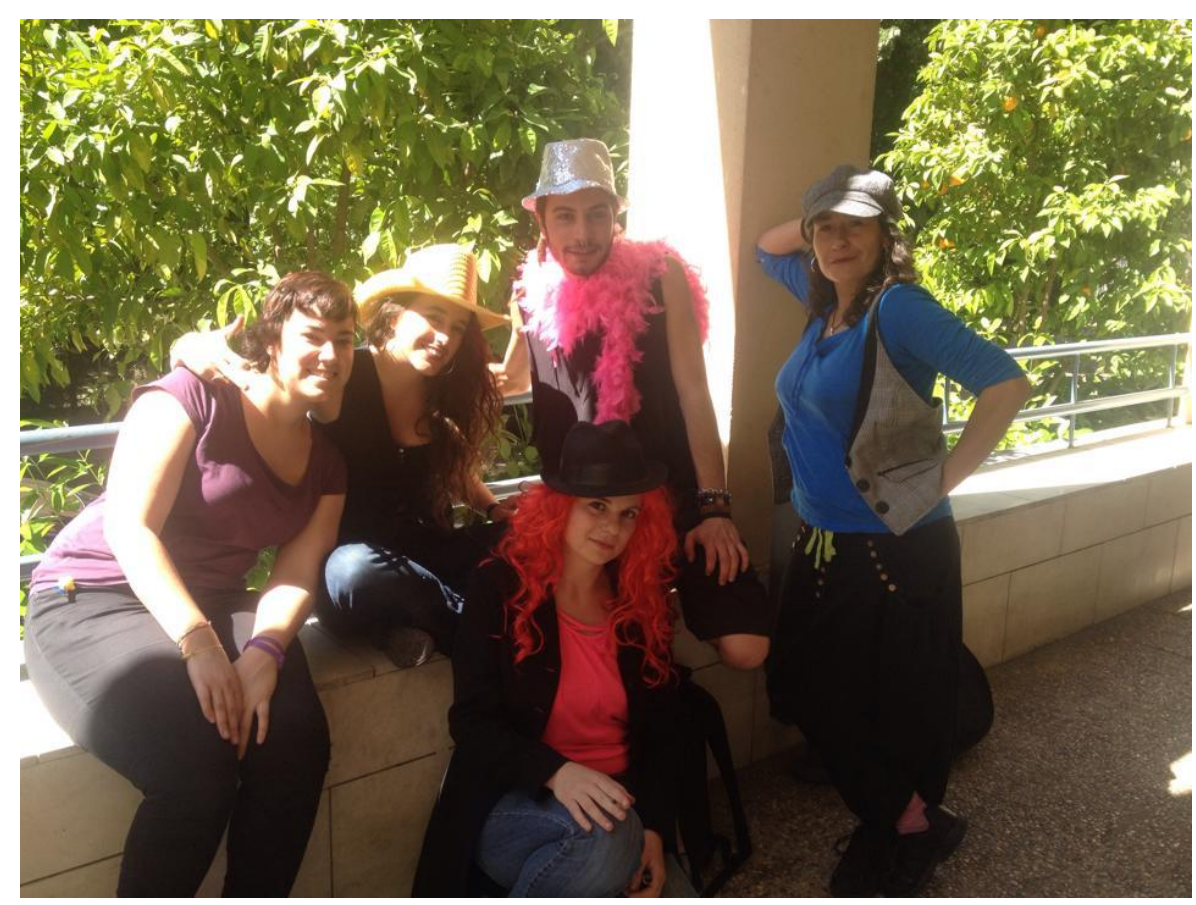

Foto $\mathrm{n}$ 7: Presentación "Por qué les importa lo que yo haga: la producción de perversiones y jerarquías desde el discurso médico y jurídico" (MÁSTER GEMMA, Junio 2014)

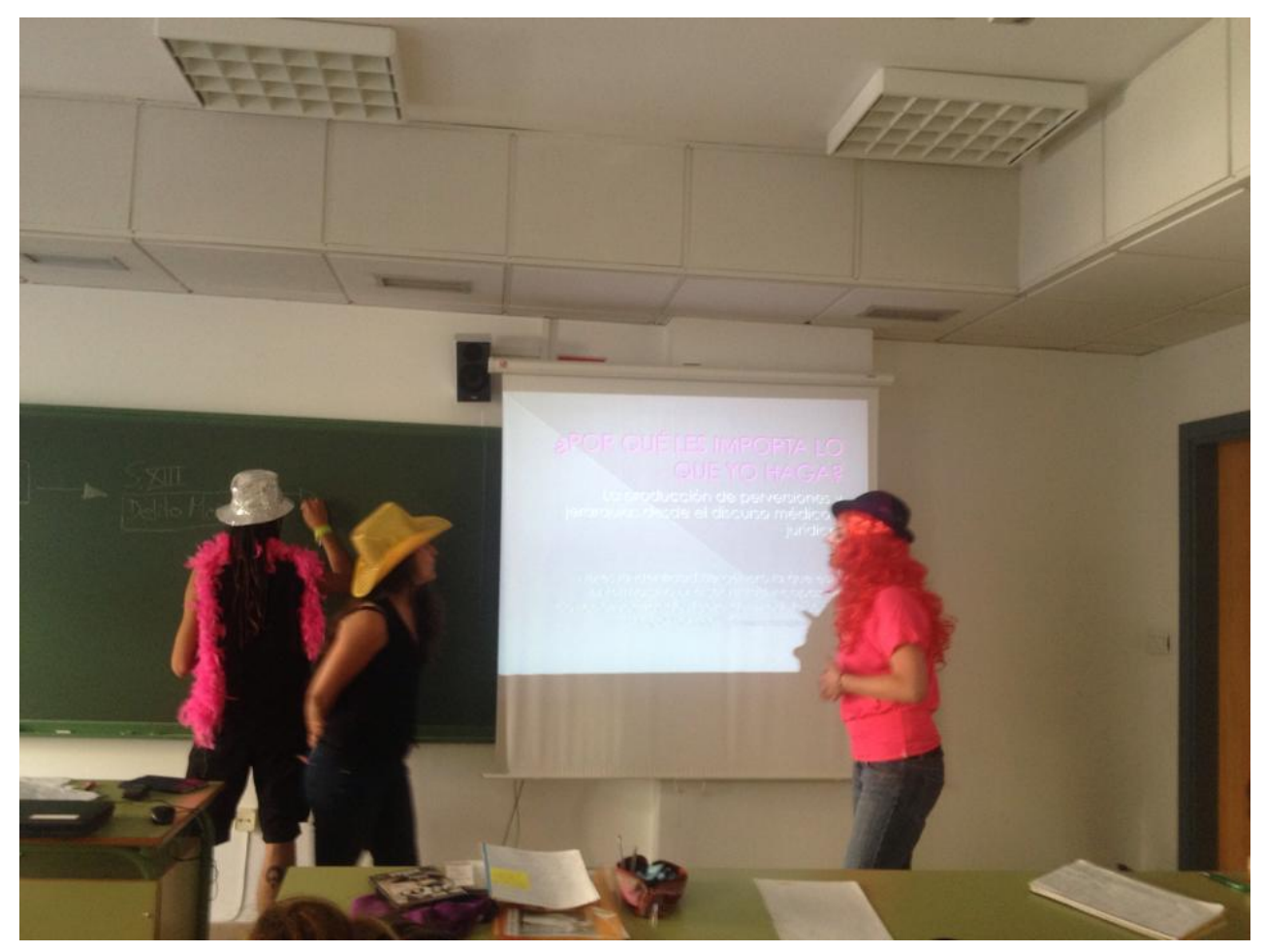

Foto № 8: Presentación “Por qué les importa lo que yo haga: la producción de perversiones y jerarquías desde el discurso médico y jurídico" (MÁSTER GEMMA, Junio 2014) 
ANEXO № 7.

\section{FOTOS DEL MANIFIESTO PIGS}

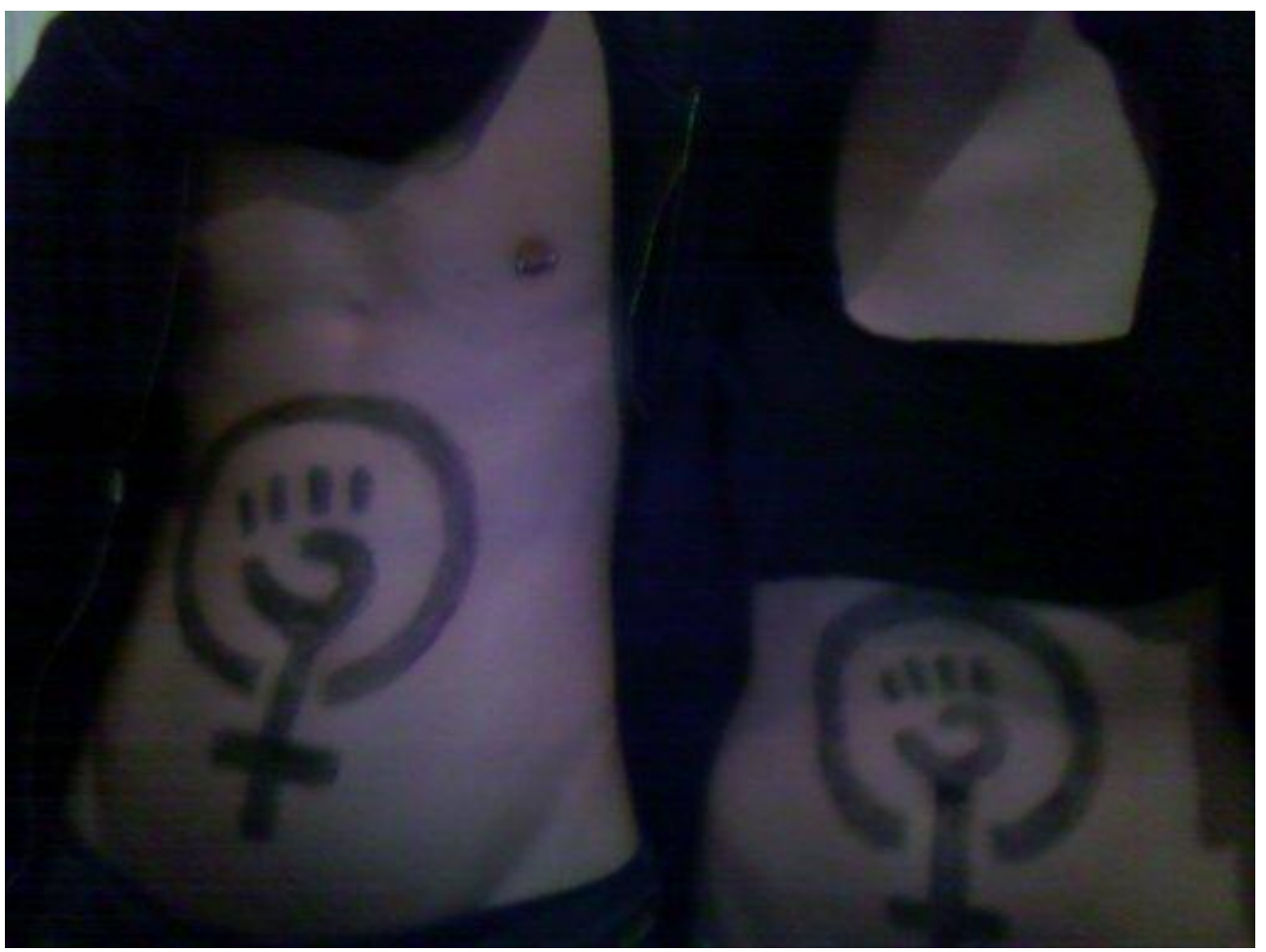

Foto no 9: MANIFIESTO PIGS (Diciembre 2014)

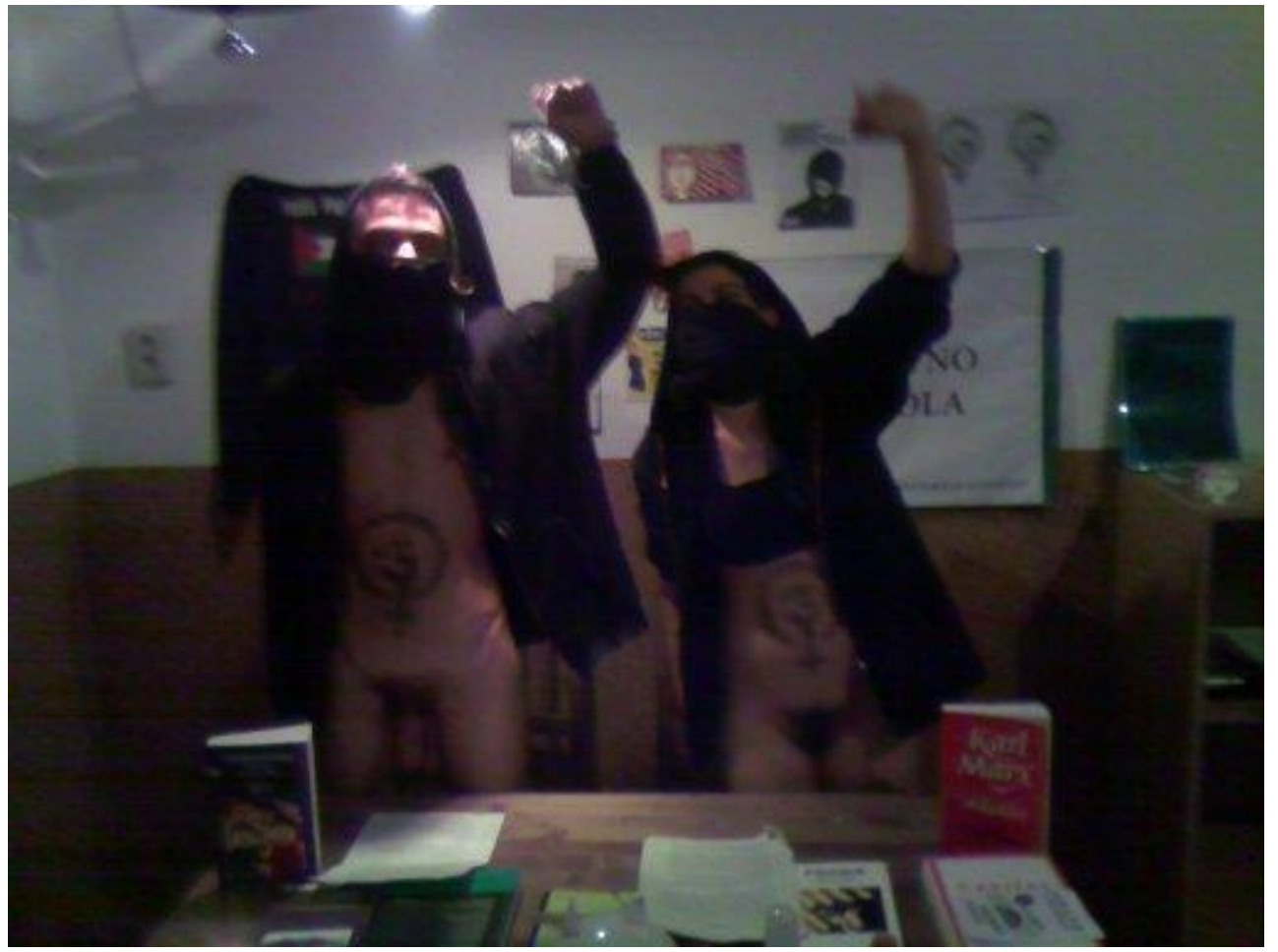

Foto $n$ ㅇ 10: MANIFIESTO PIGS (Diciembre 2014) 


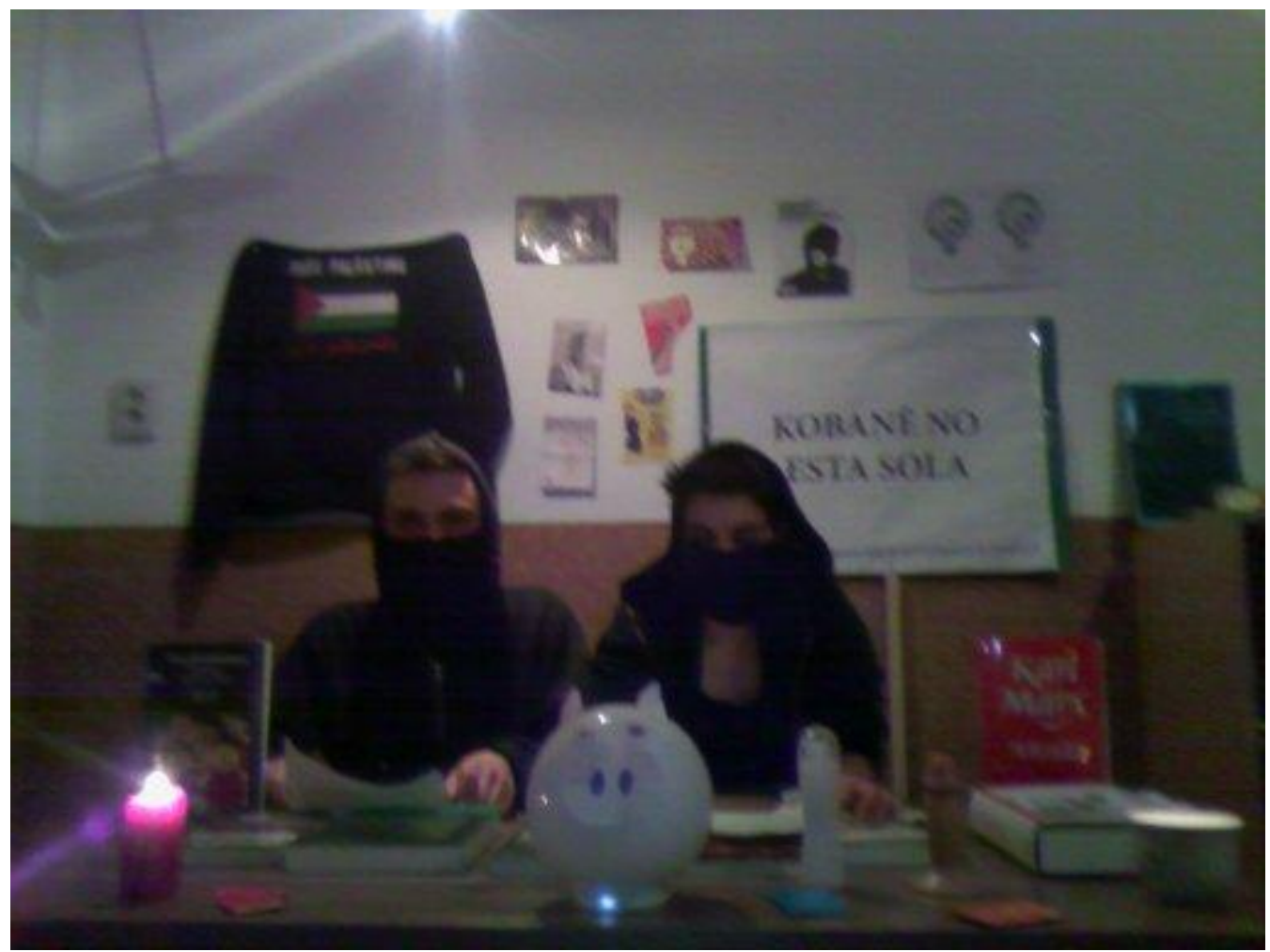

Foto no 11: MANIFIESTO PIGS (Diciembre 2014)

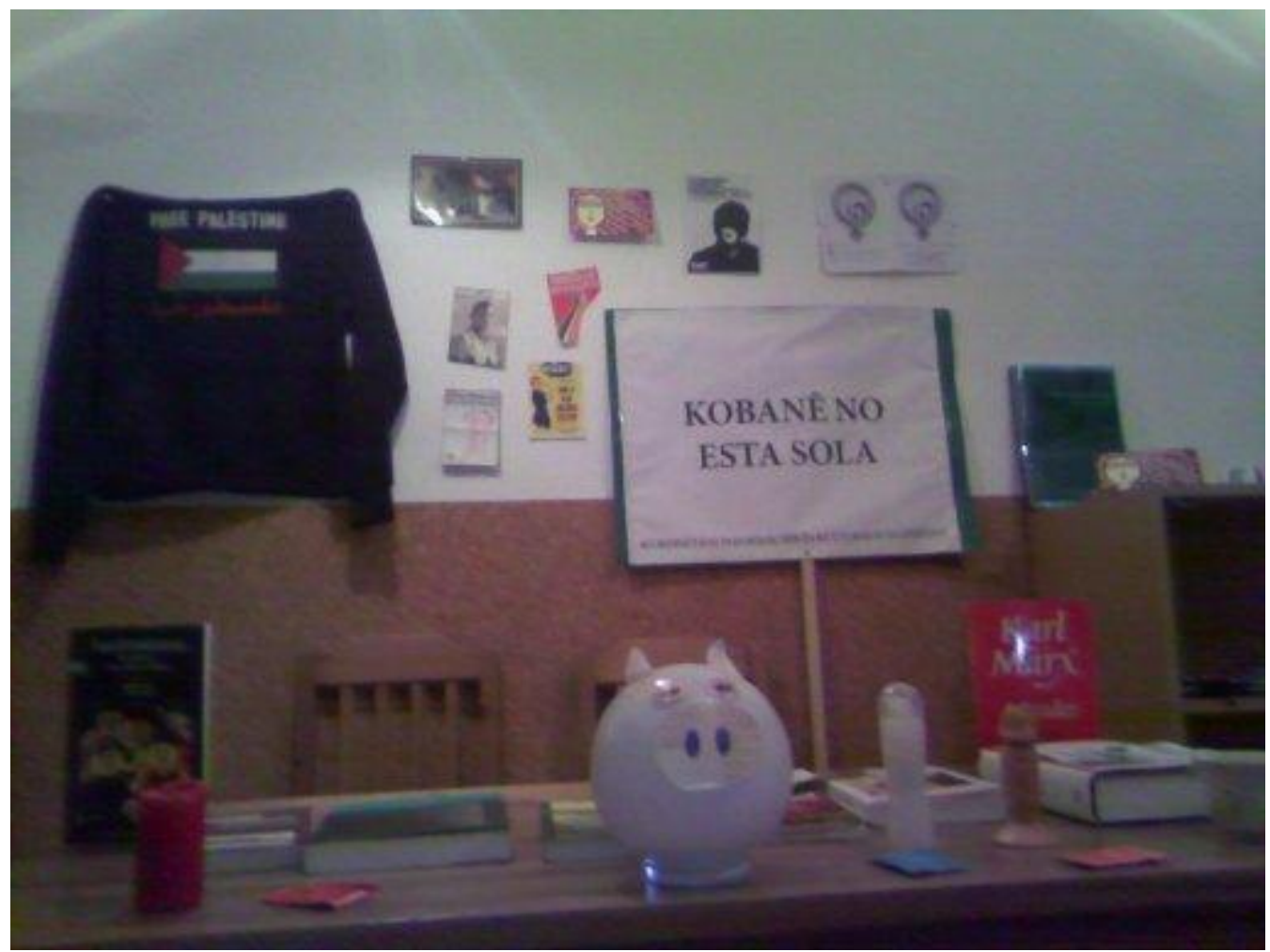

Foto $n$ ㅇ 12: MANIFIESTO PIGS (Diciembre 2014) 
ANEXO № 8.

FOTOS DE MANADA SALVAJE

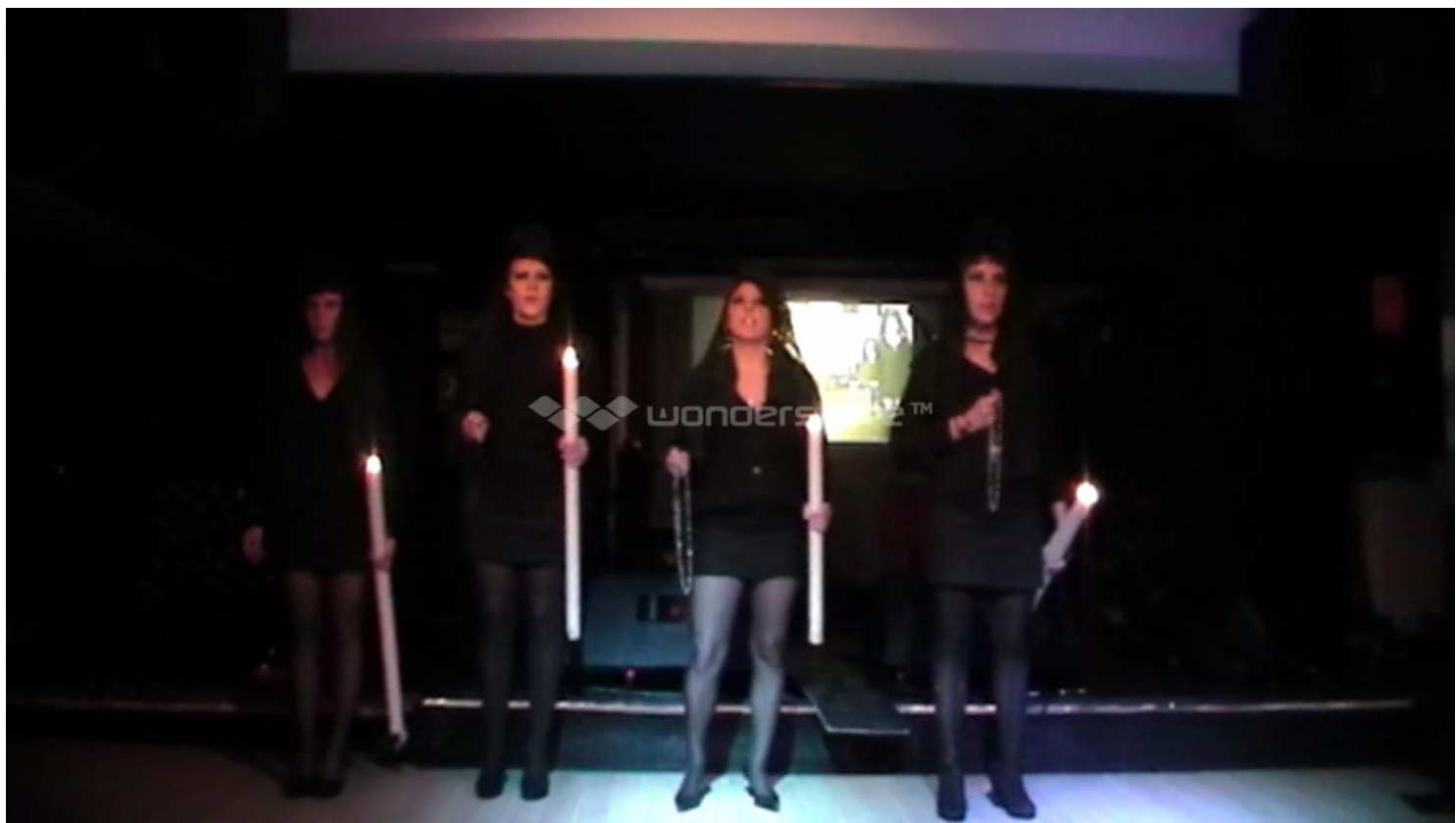

Foto no 13: Performance “OLE TU COÑO”

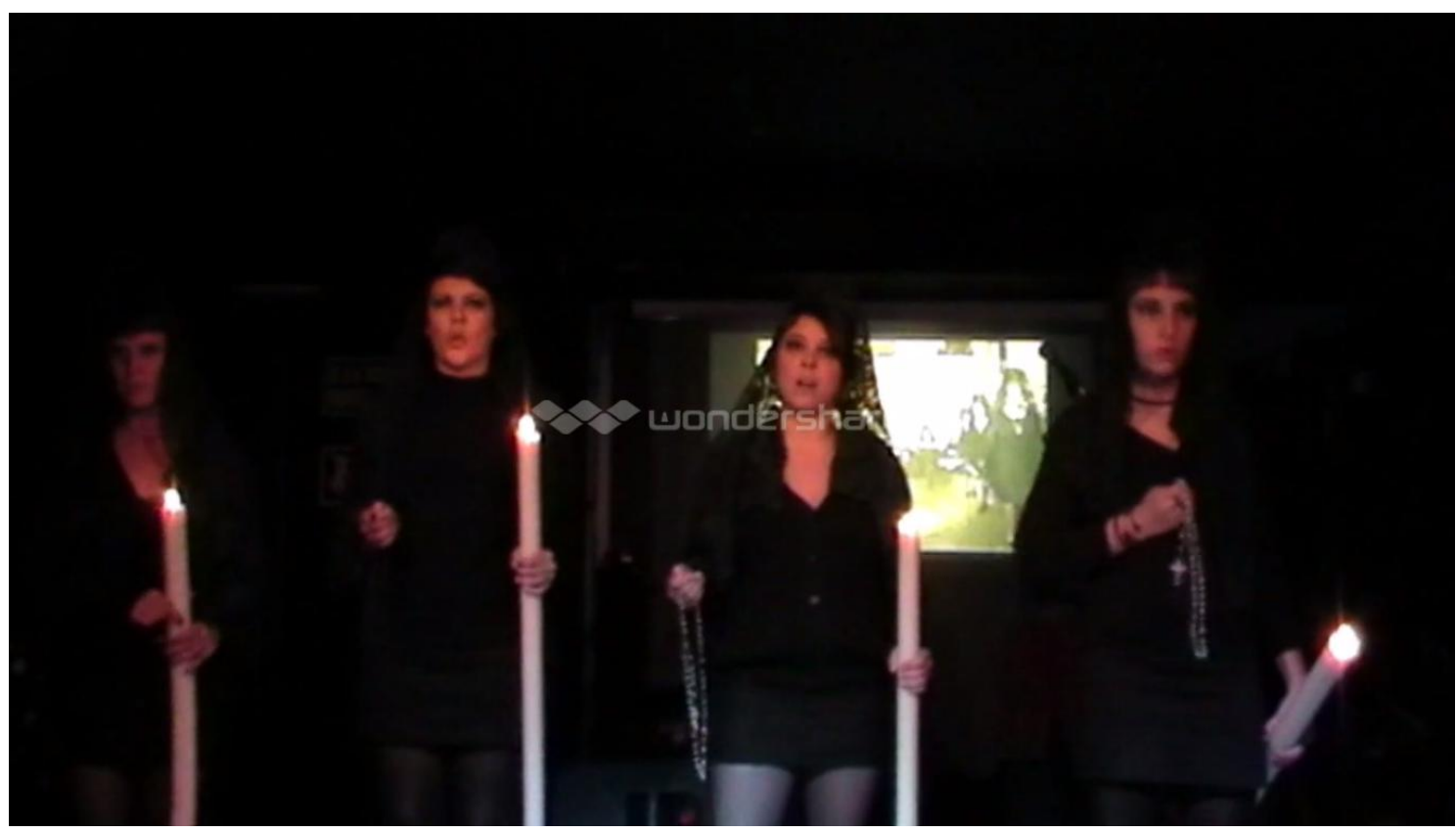

Foto no 14: Performance "OLE TU COÑO" 


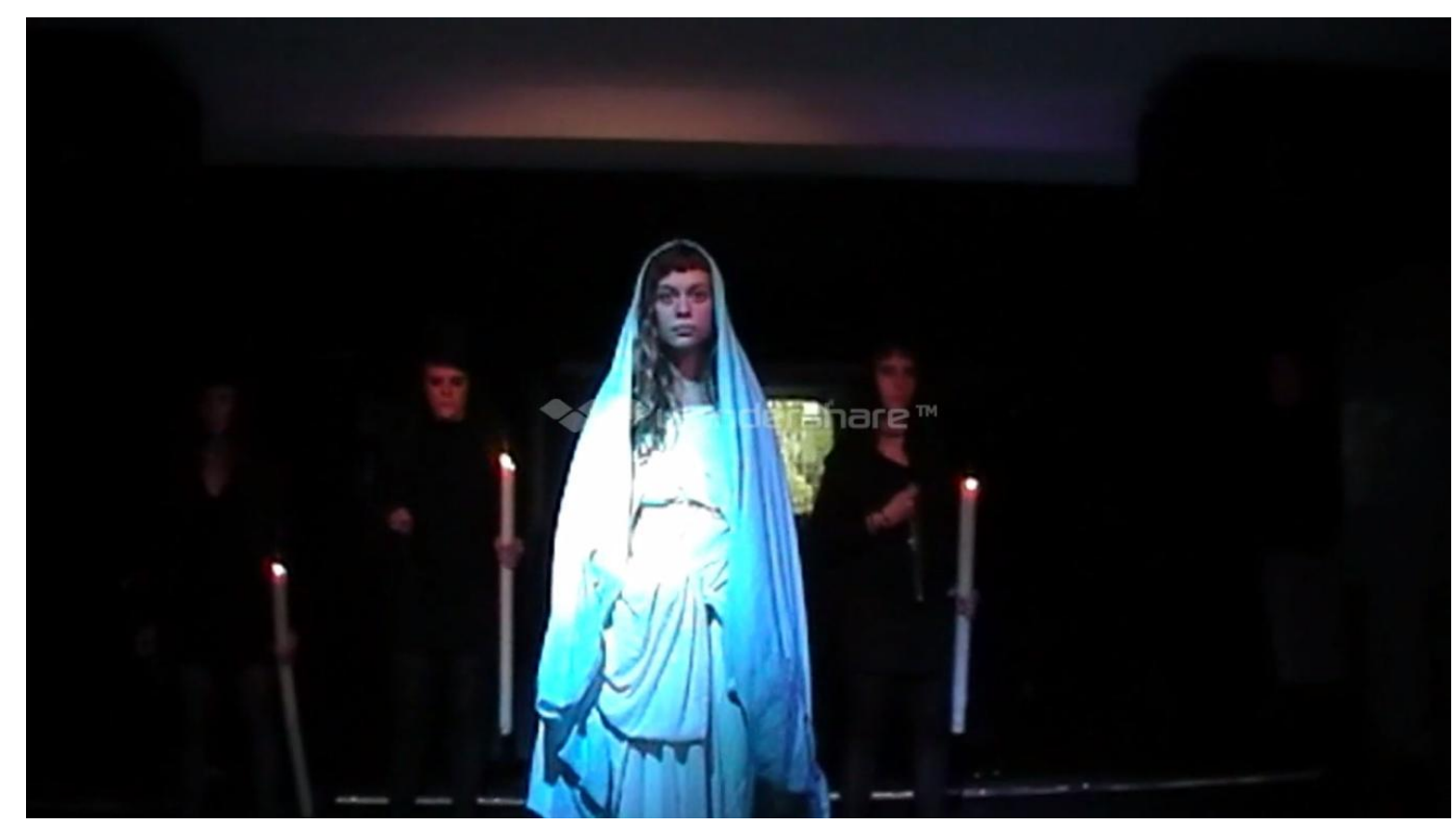

Foto no 15: Performance "OLE TU COÑO"

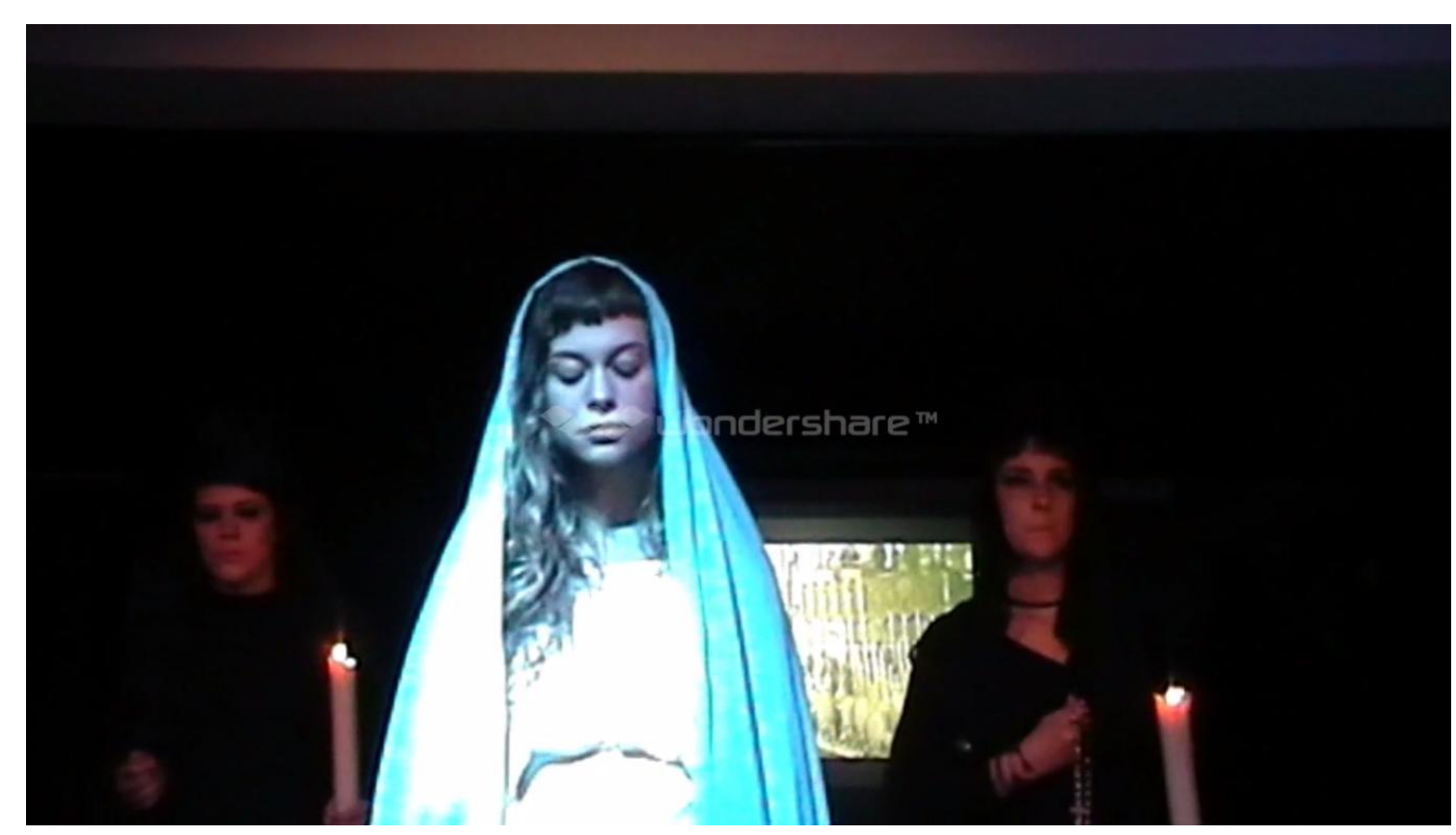

Foto no 16: Performance "OLE TU COÑO" 


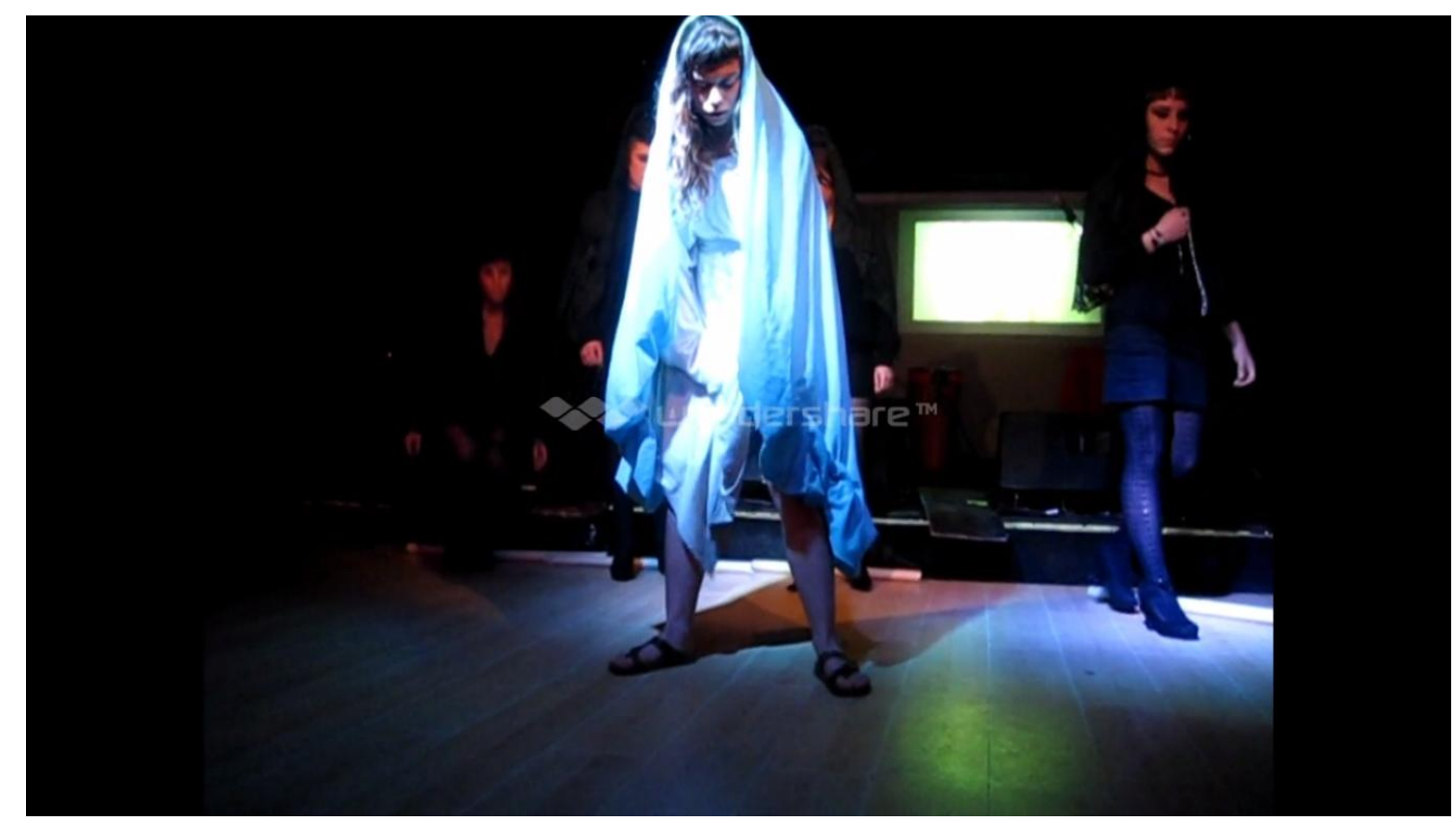

Foto no 17: Performance "OLE TU COÑO"

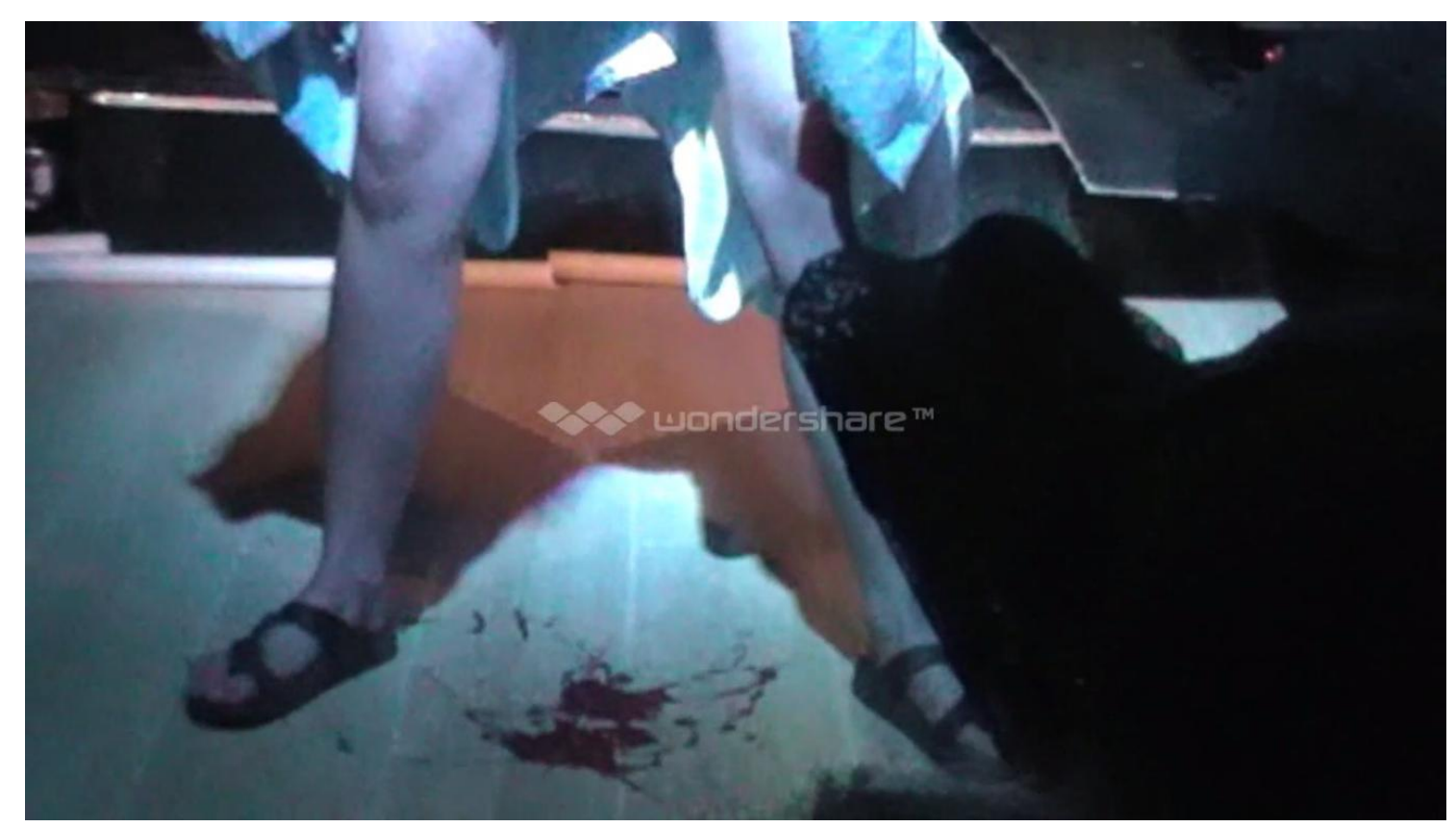

Foto no 18: Performance "OLE TU COÑO" 


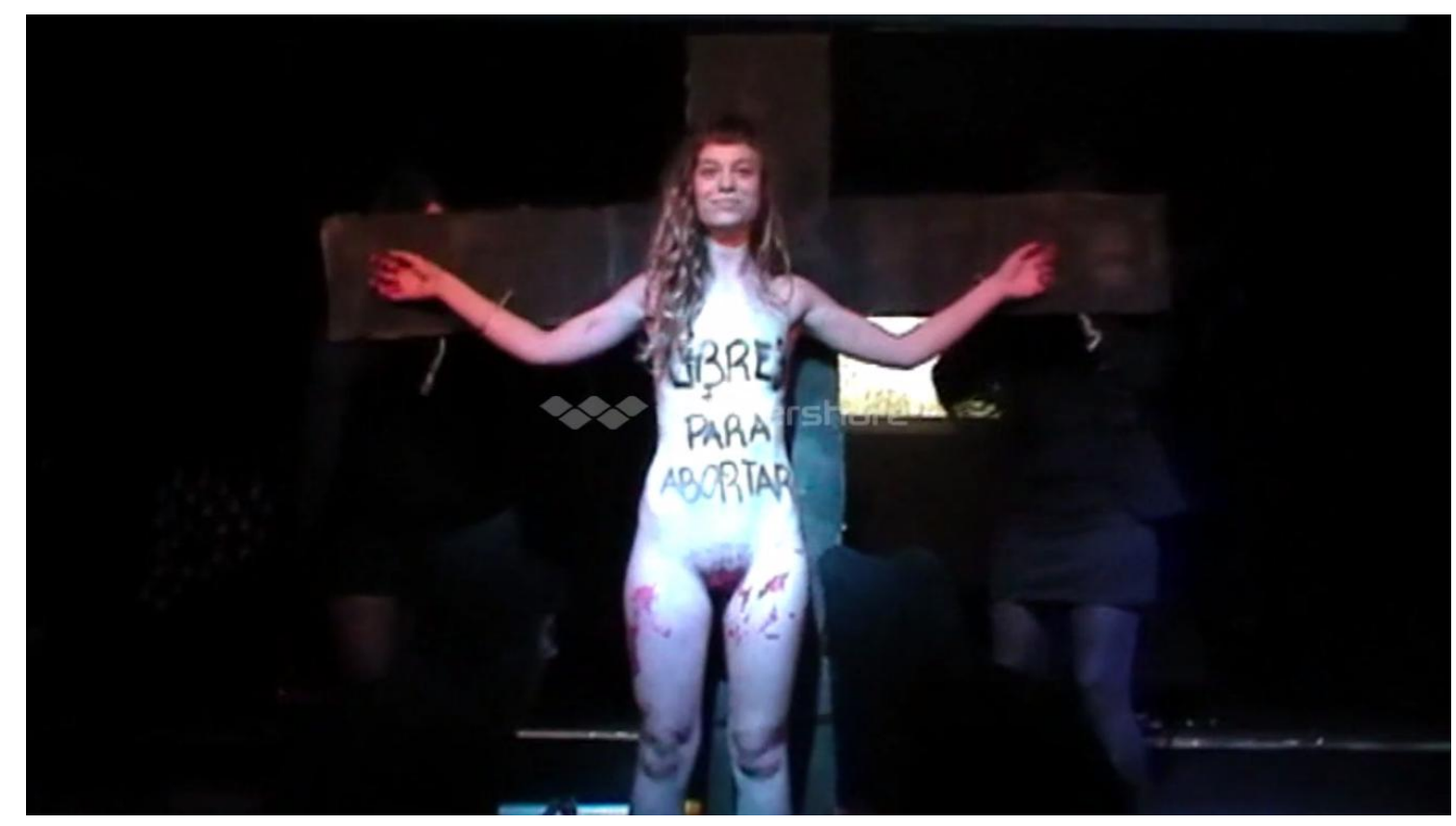

Foto no 19: Performance "OLE TU COÑO"

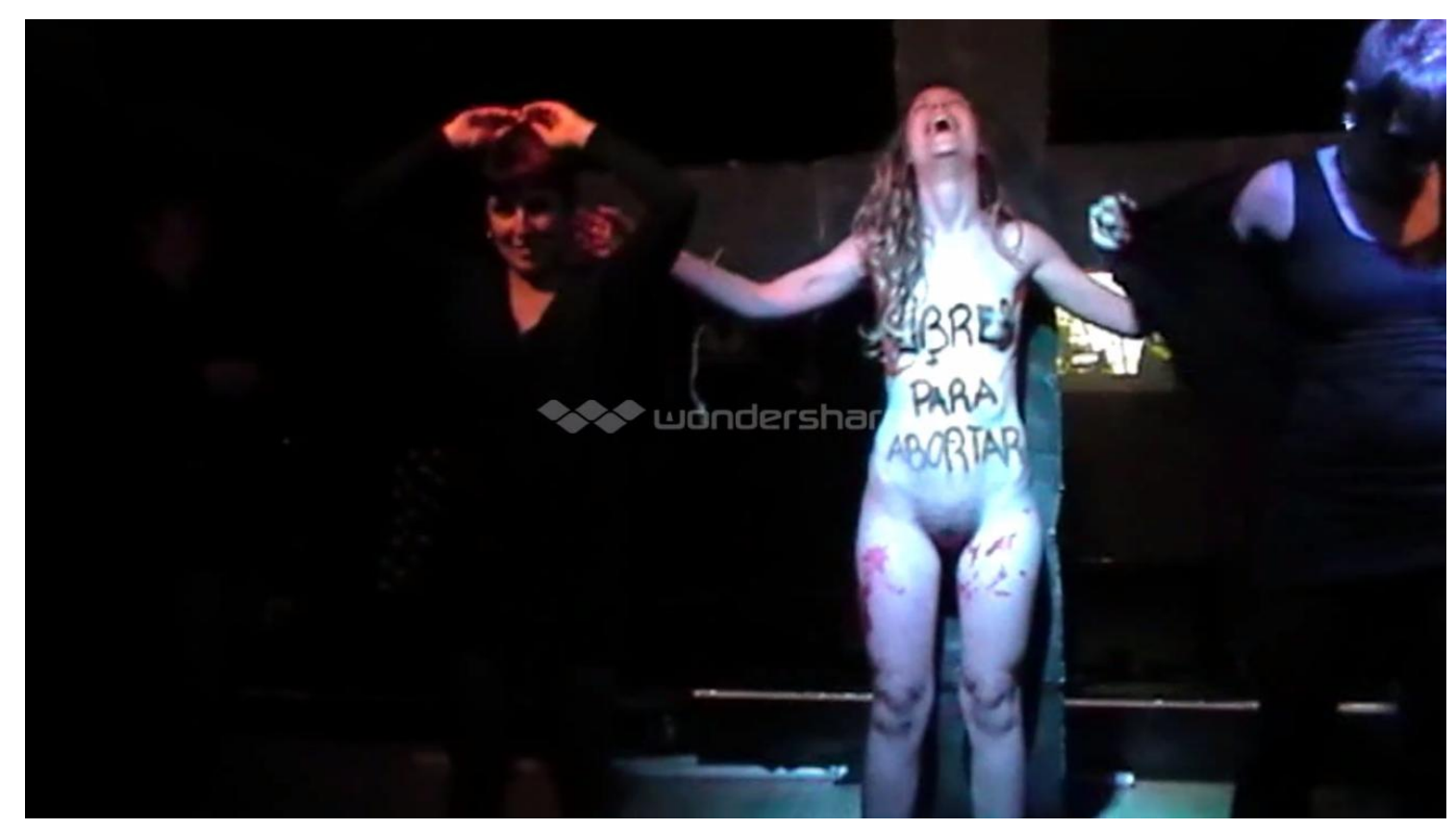

Foto no 20: Performance "OLE TU COÑO" 


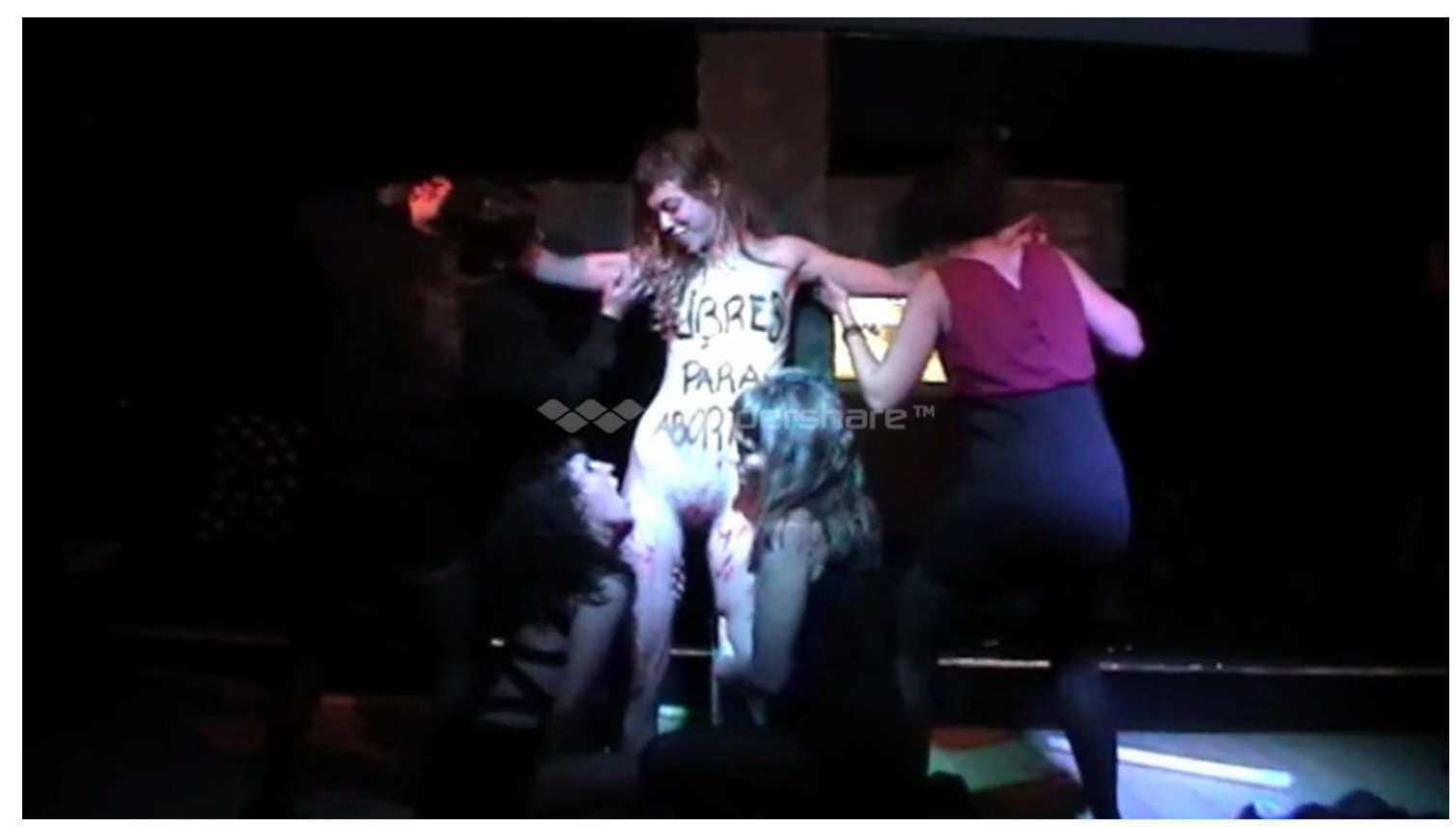

Foto no 21: Performance "OLE TU COÑO"

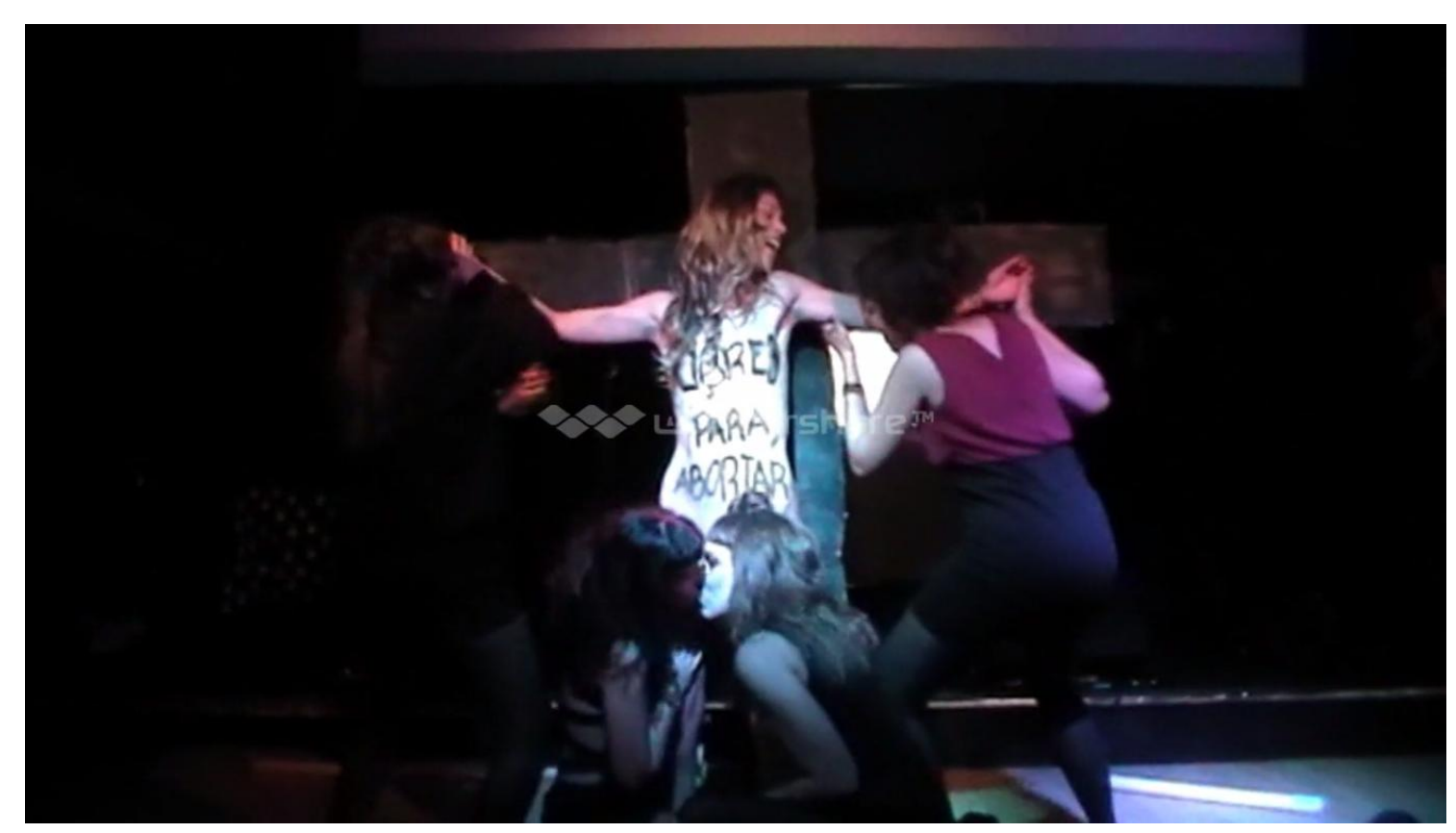

Foto no 22: Performance "OLE TU COÑO" 


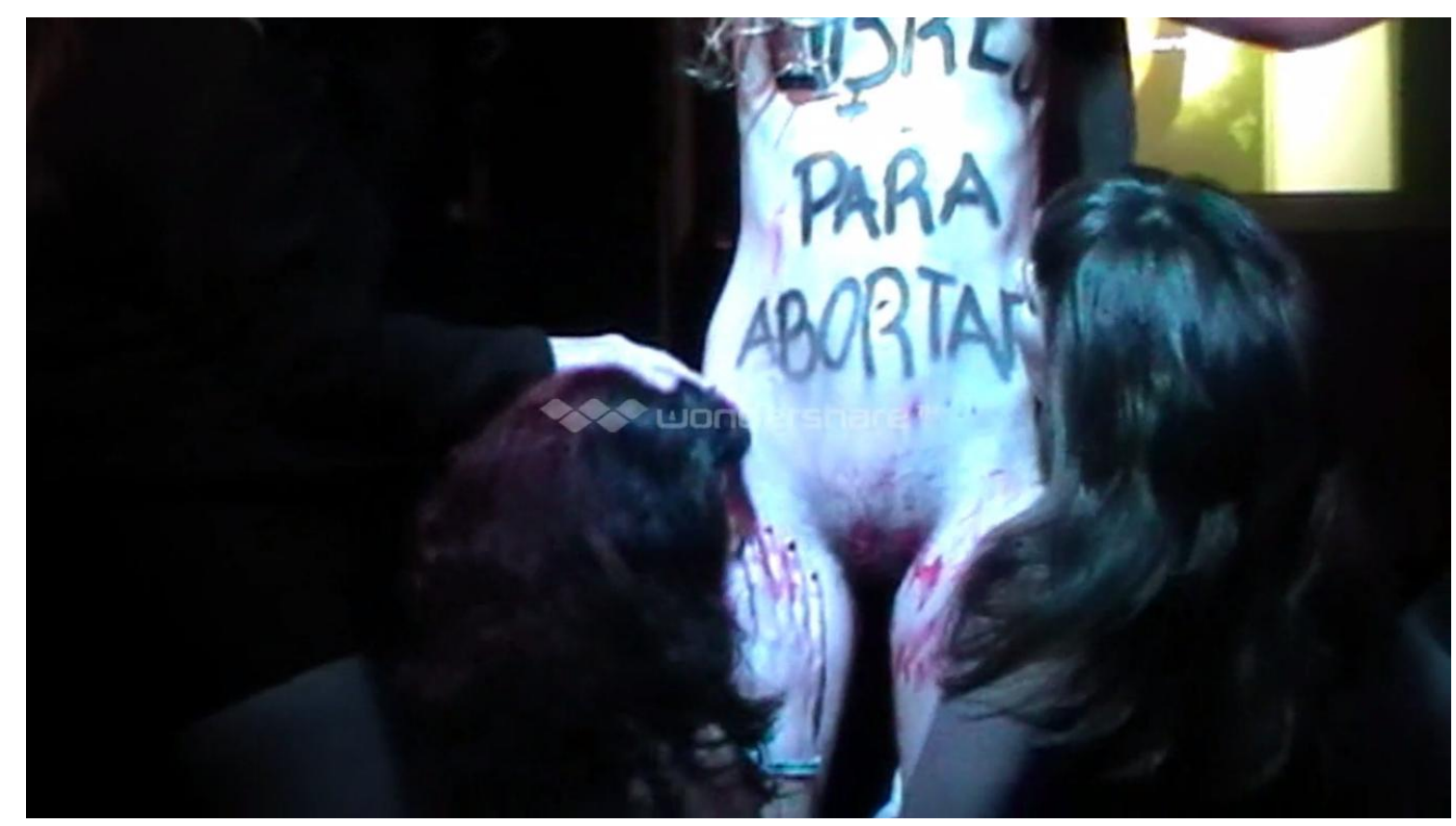

Foto no 23: Performance "OLE TU COÑO"

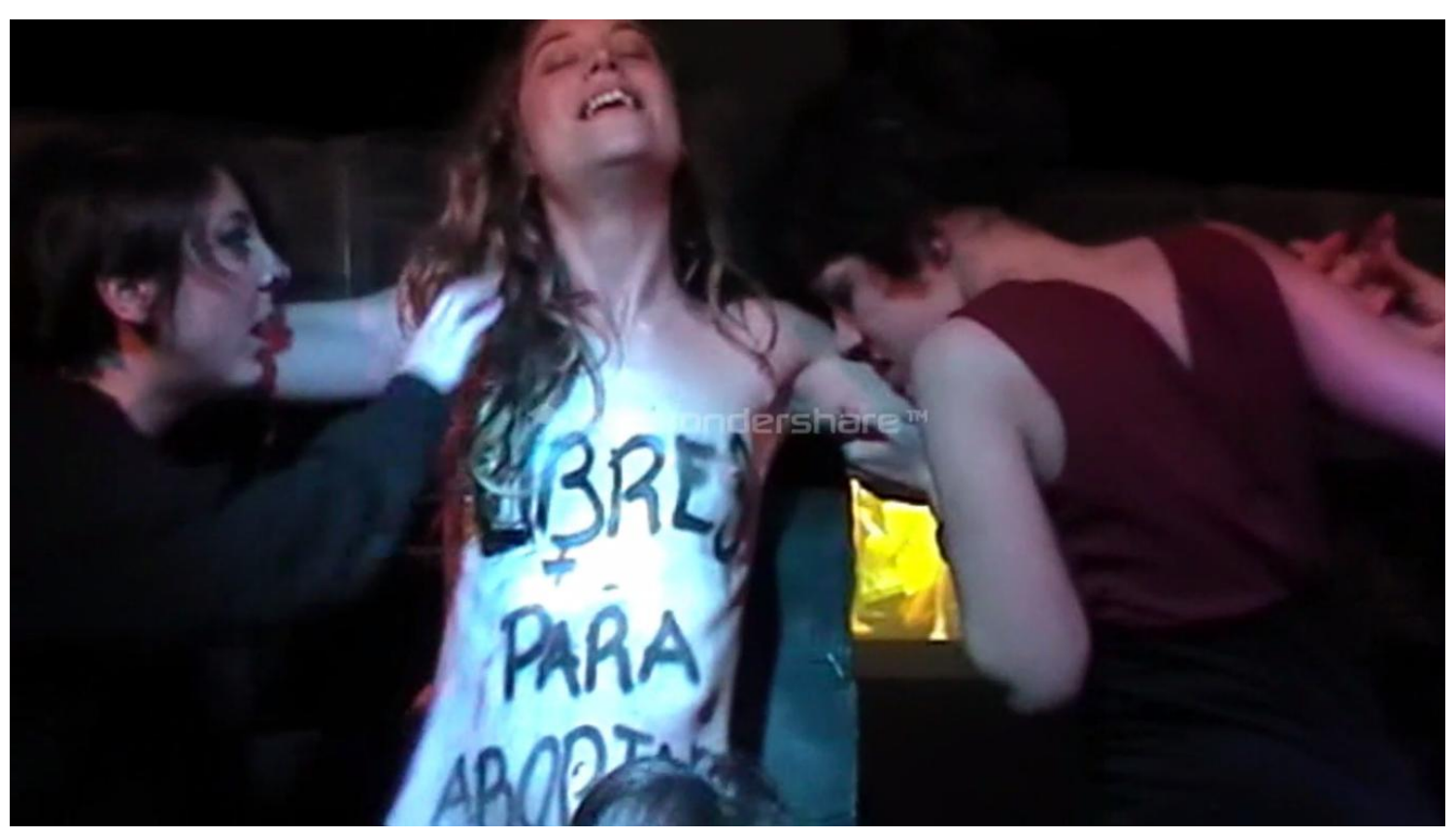

Foto no 24: Performance "OLE TU COÑO" 


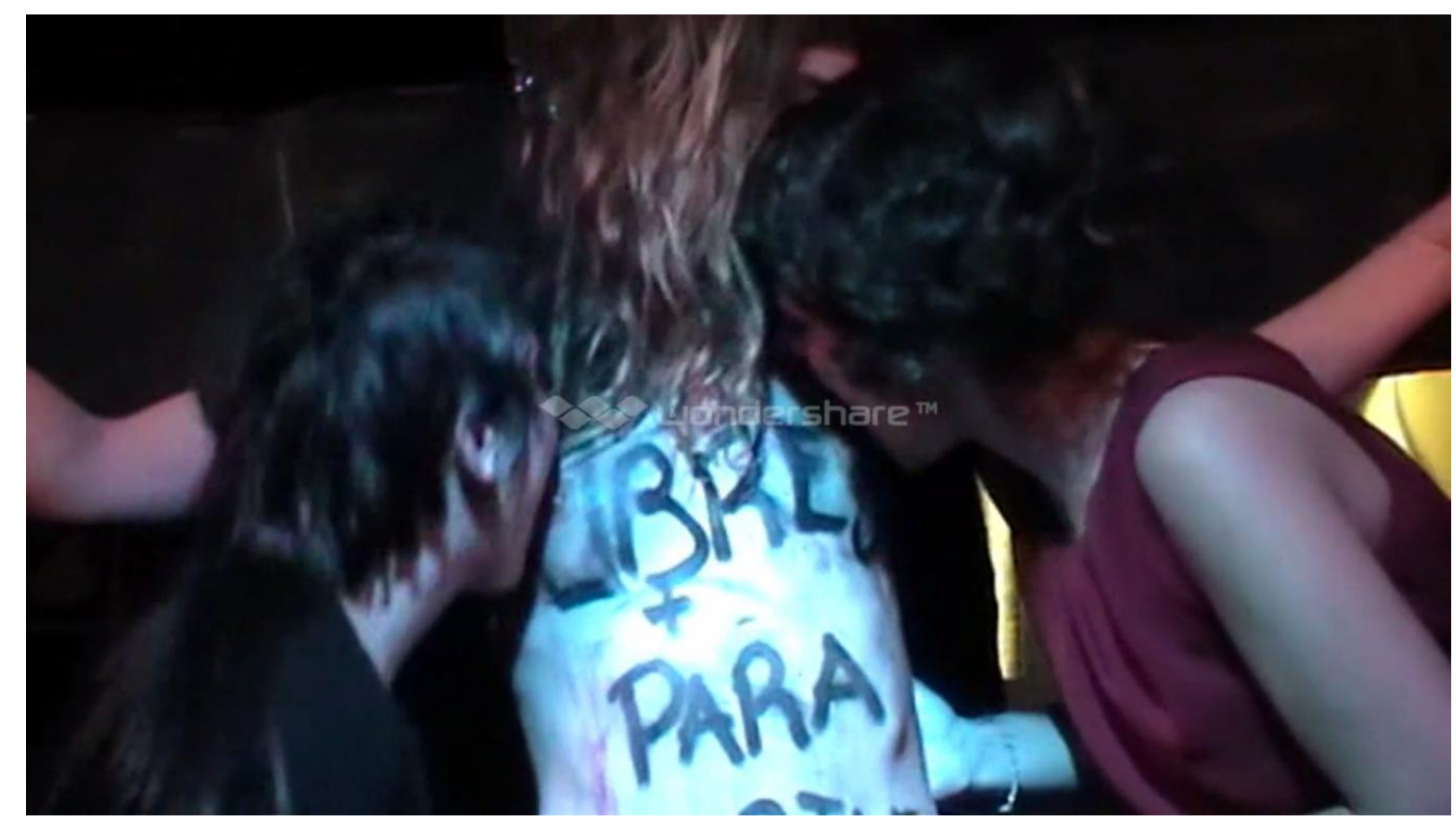

Foto no 25: Performance "OLE TU COÑO"

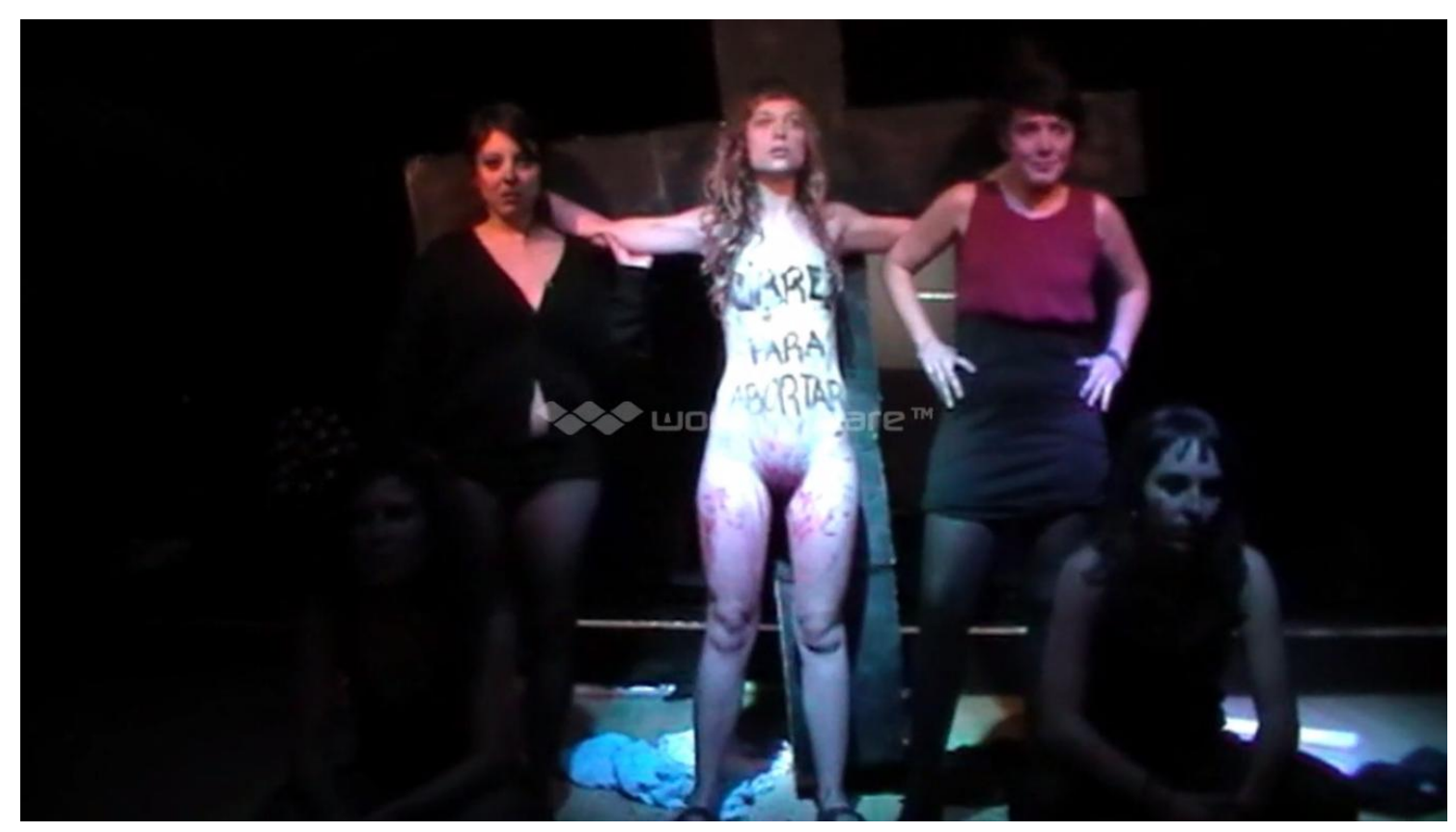

Foto no 26: Performance "OLE TU COÑO" 
ANEXO № 9.

\section{FOTOS Y CARTELES DE LA FÁBRIKA CRÍTICA}

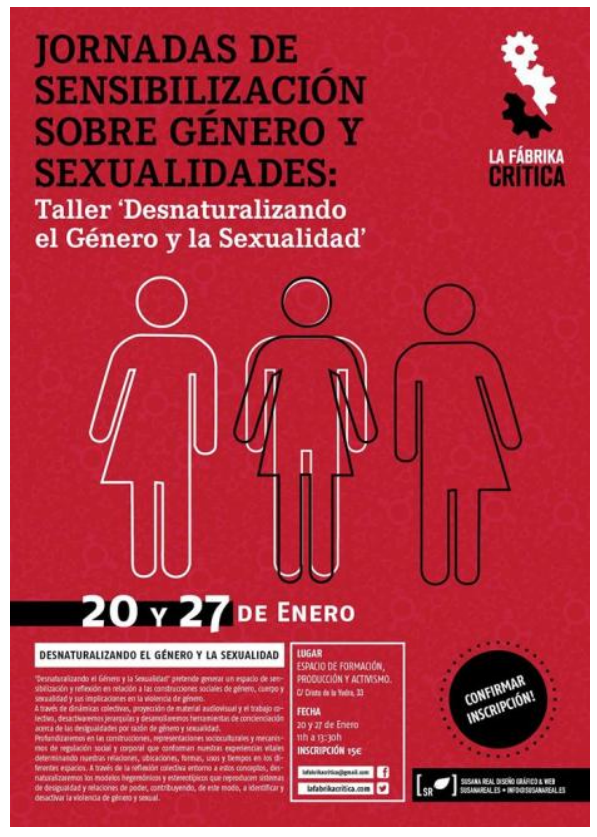

Foto $n$ ㅇ 27: Taller "Desnaturalizando el Género y la Sexualidad"

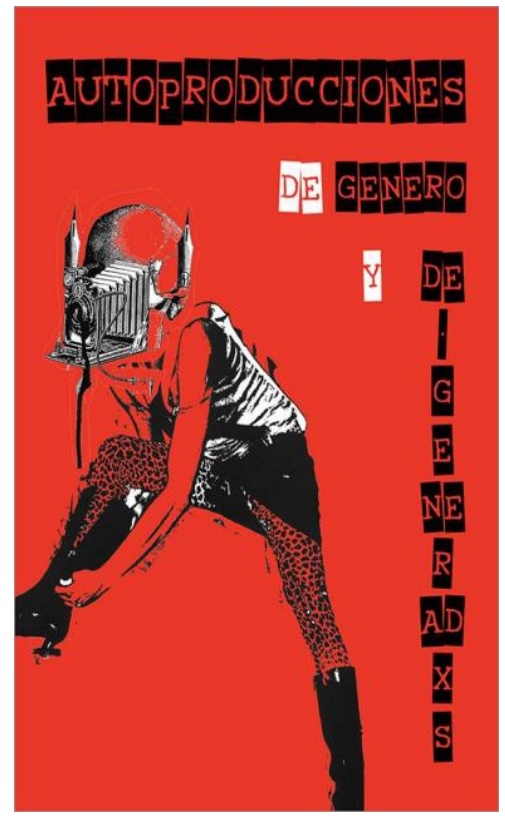

Foto $\mathrm{n}$ - 28: Taller "Autoproducciones de Género y Degeneradxs"

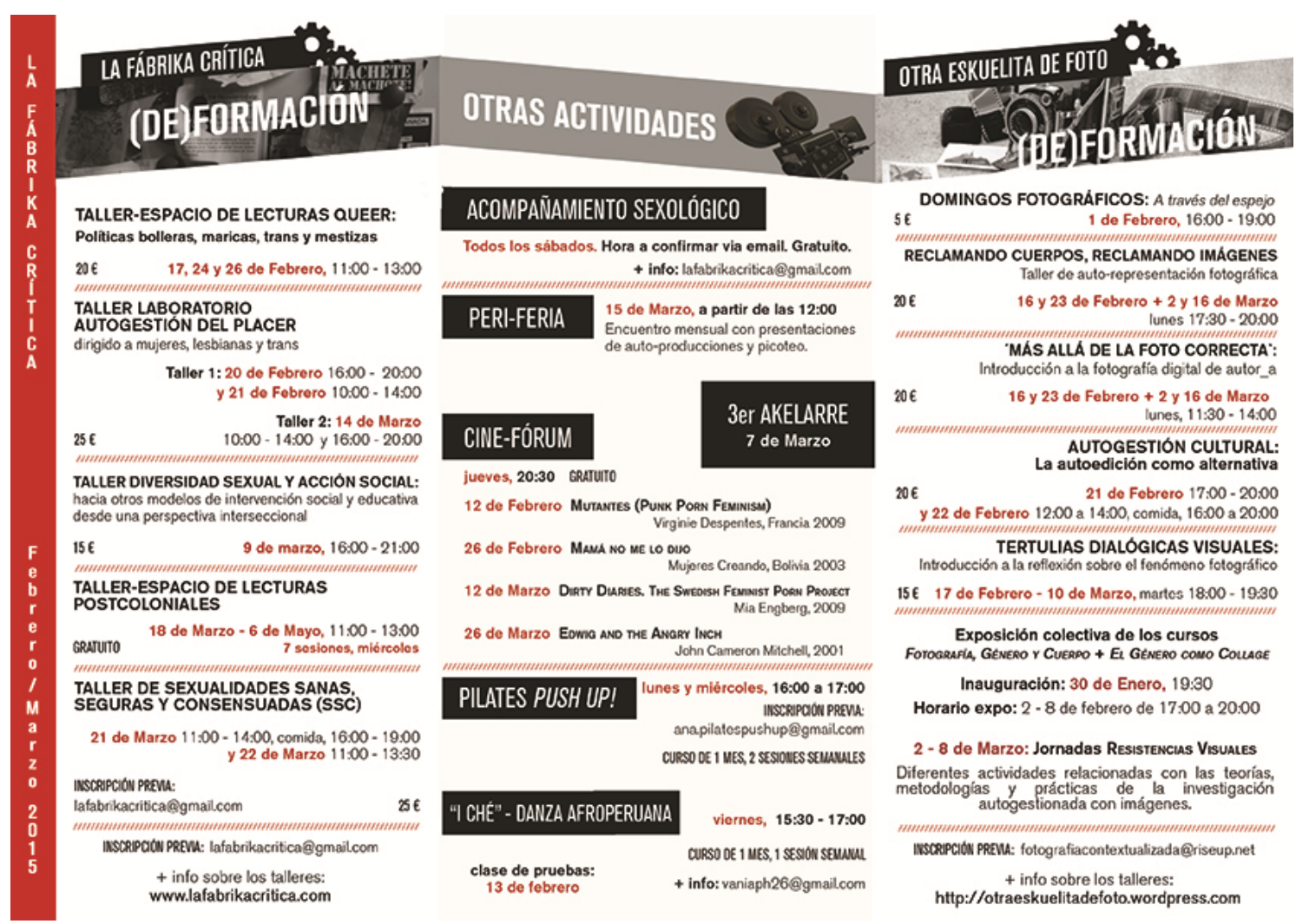

Foto no 29: Actividades Febrero/Marzo 2015 


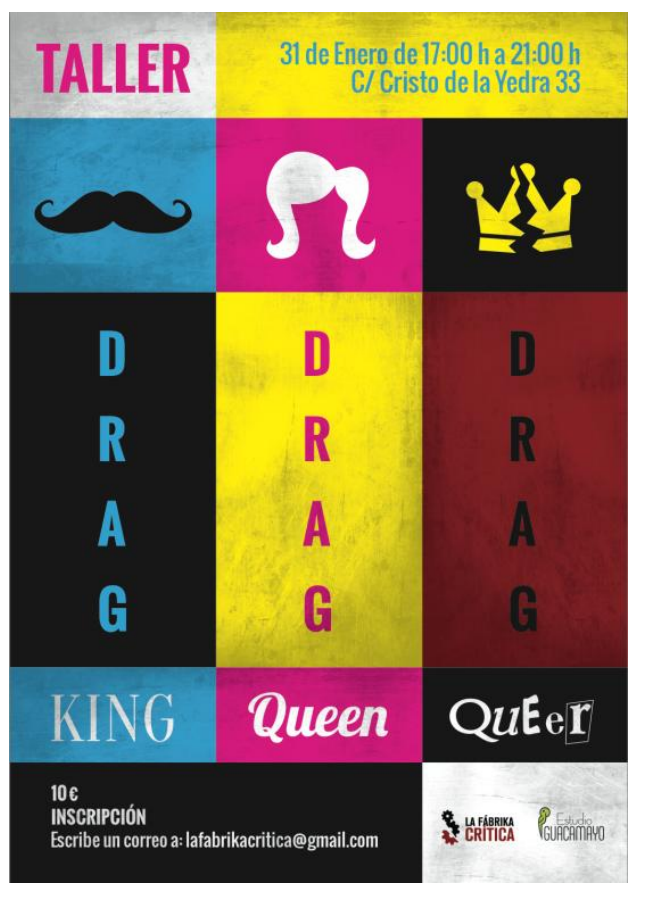

Foto no 30: Taller “Drag King/Queen/Queer”

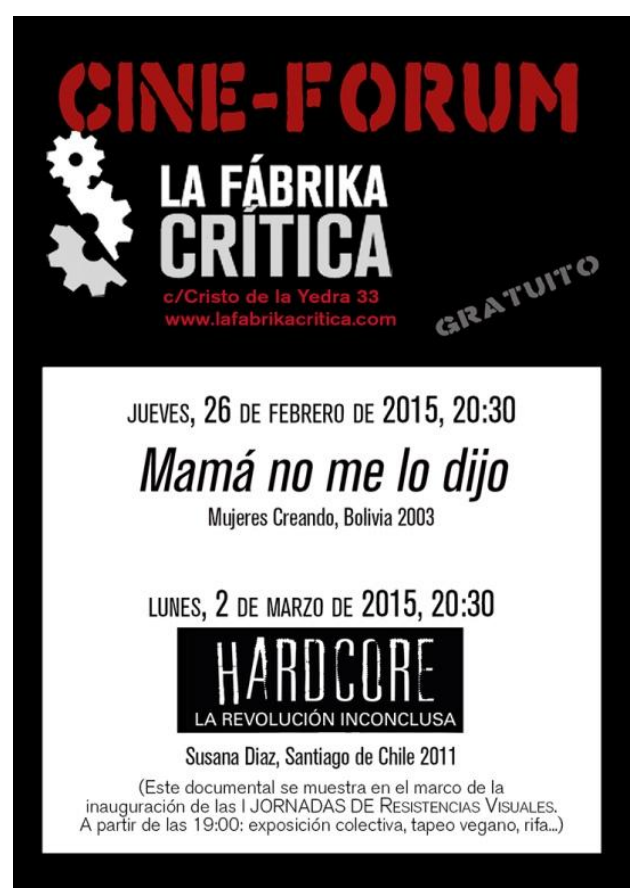

Foto $\mathrm{n}$ 31: Cine-Forum "Mamá no me lo dijo"

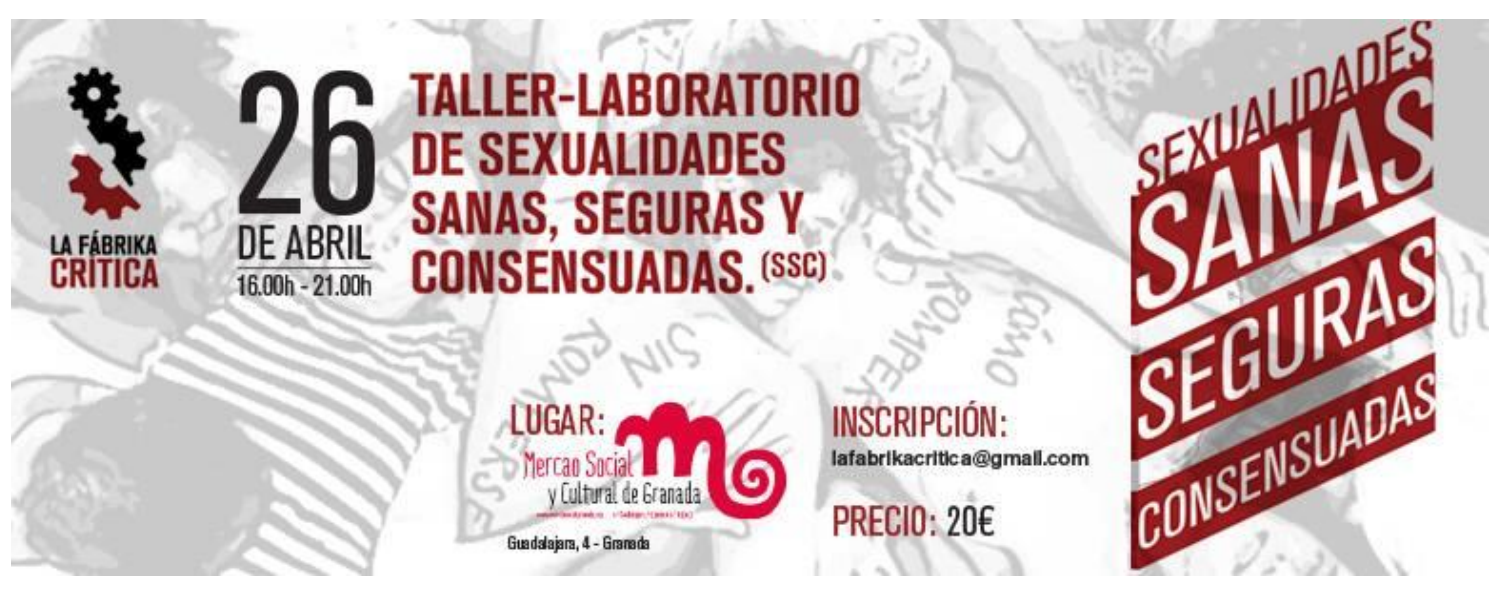

Foto no 31: Taller-Laboratorio de "Sexualidades Sanas, Seguras y Consensuadas" 


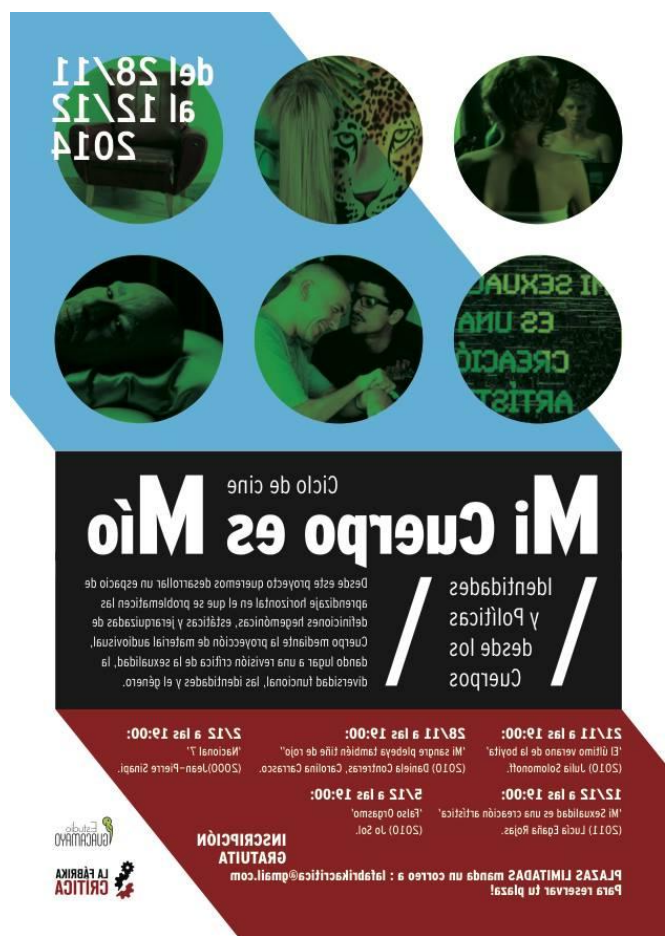

Foto no 32: Ciclo de cine "Mi cuerpo es mío"

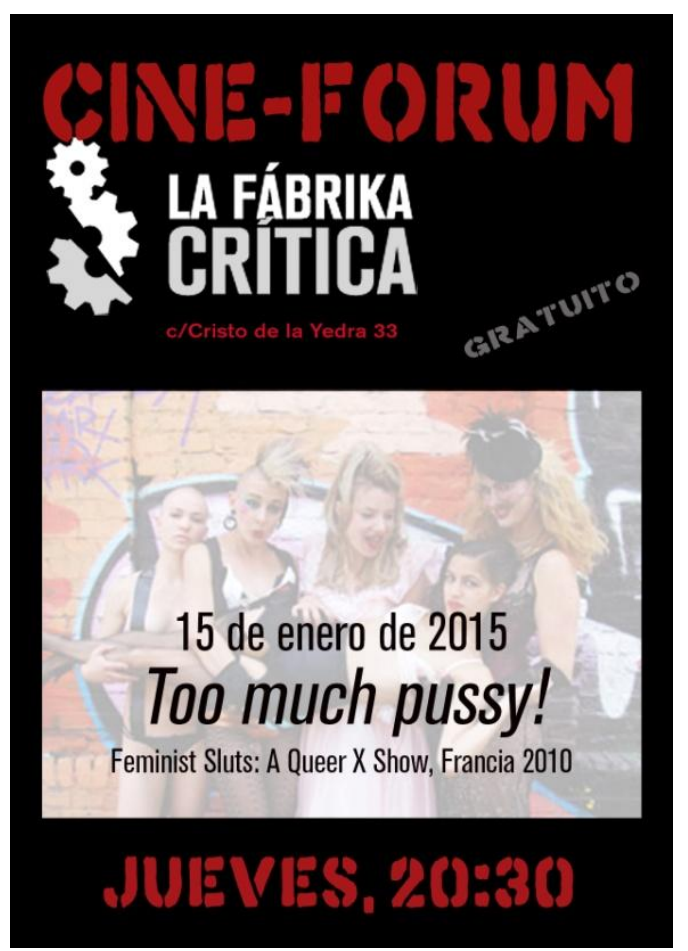

Foto no 34: Cine-Forum "Too much pussy!"

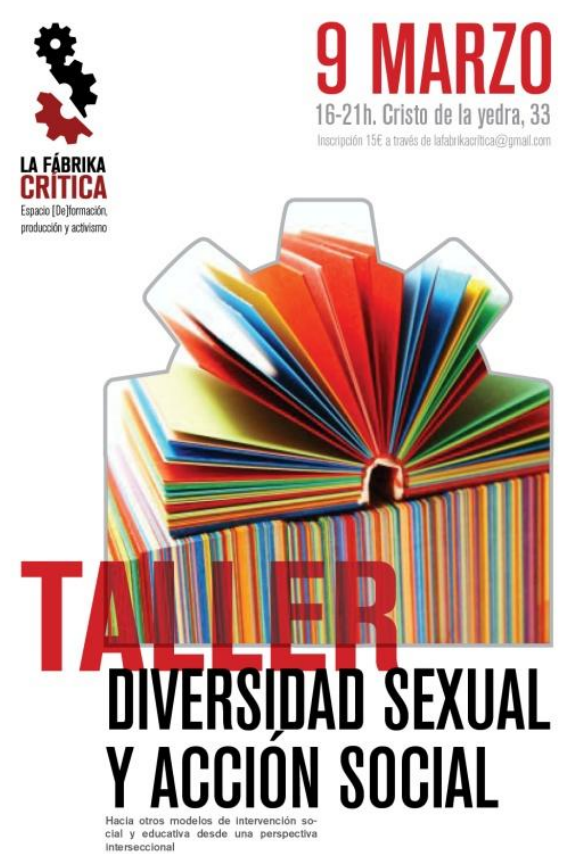

Foto $\mathrm{n}$ - 33: Taller "Diversidad sexual y acción social"

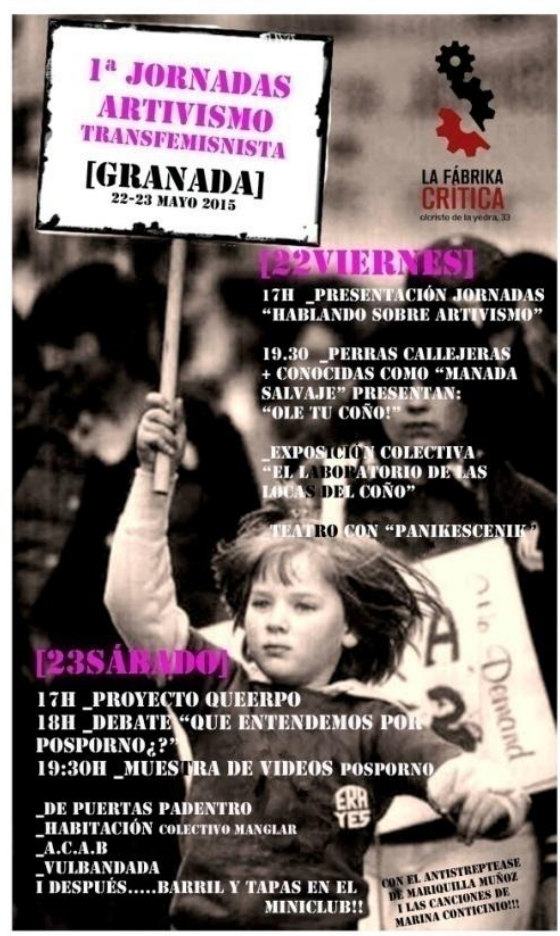

Foto no 35: “1a Jornadas de Artivismo Transfeminista" 


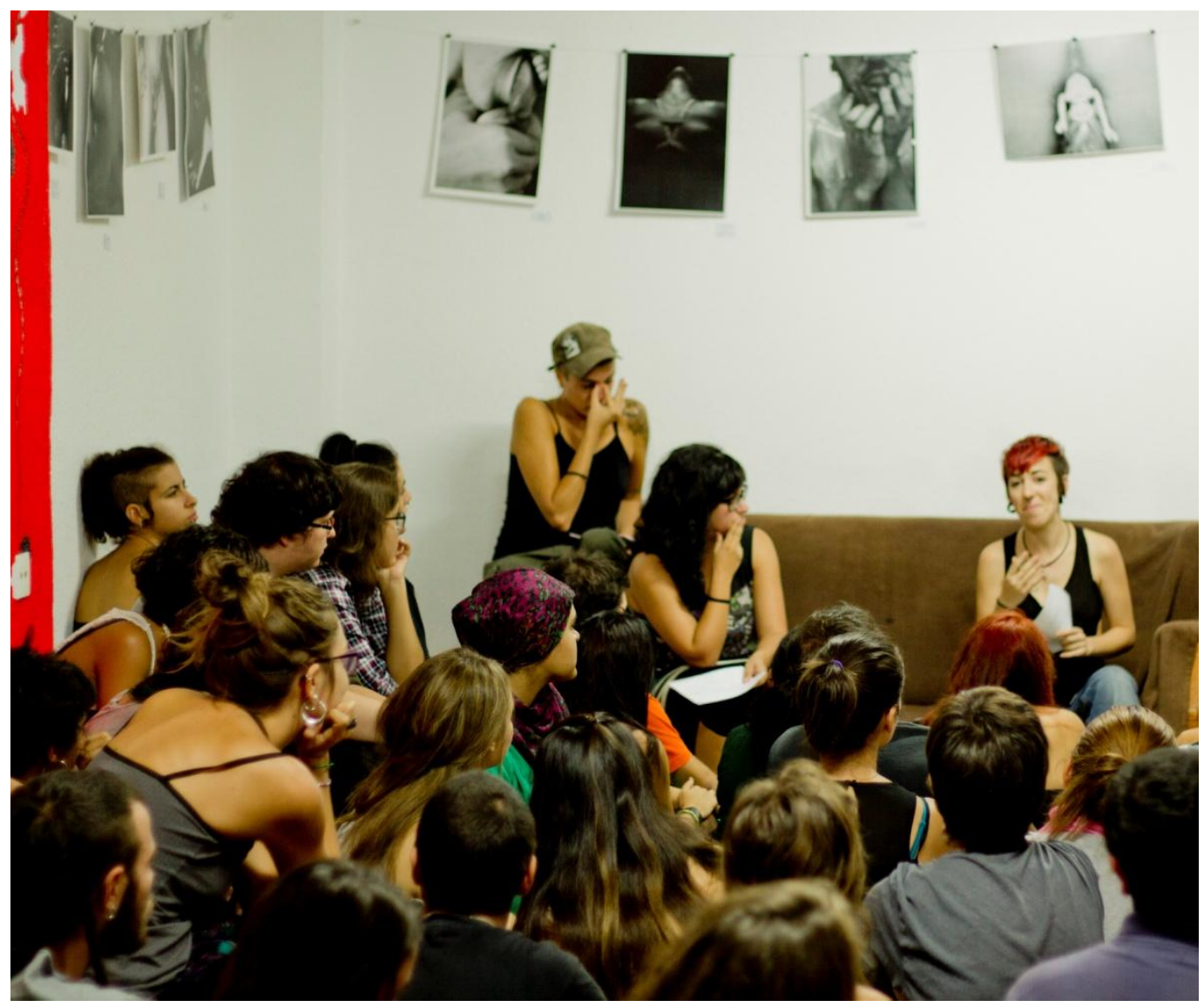

Foto no 36: Presentación del proyecto fotográfico "Monstruos"

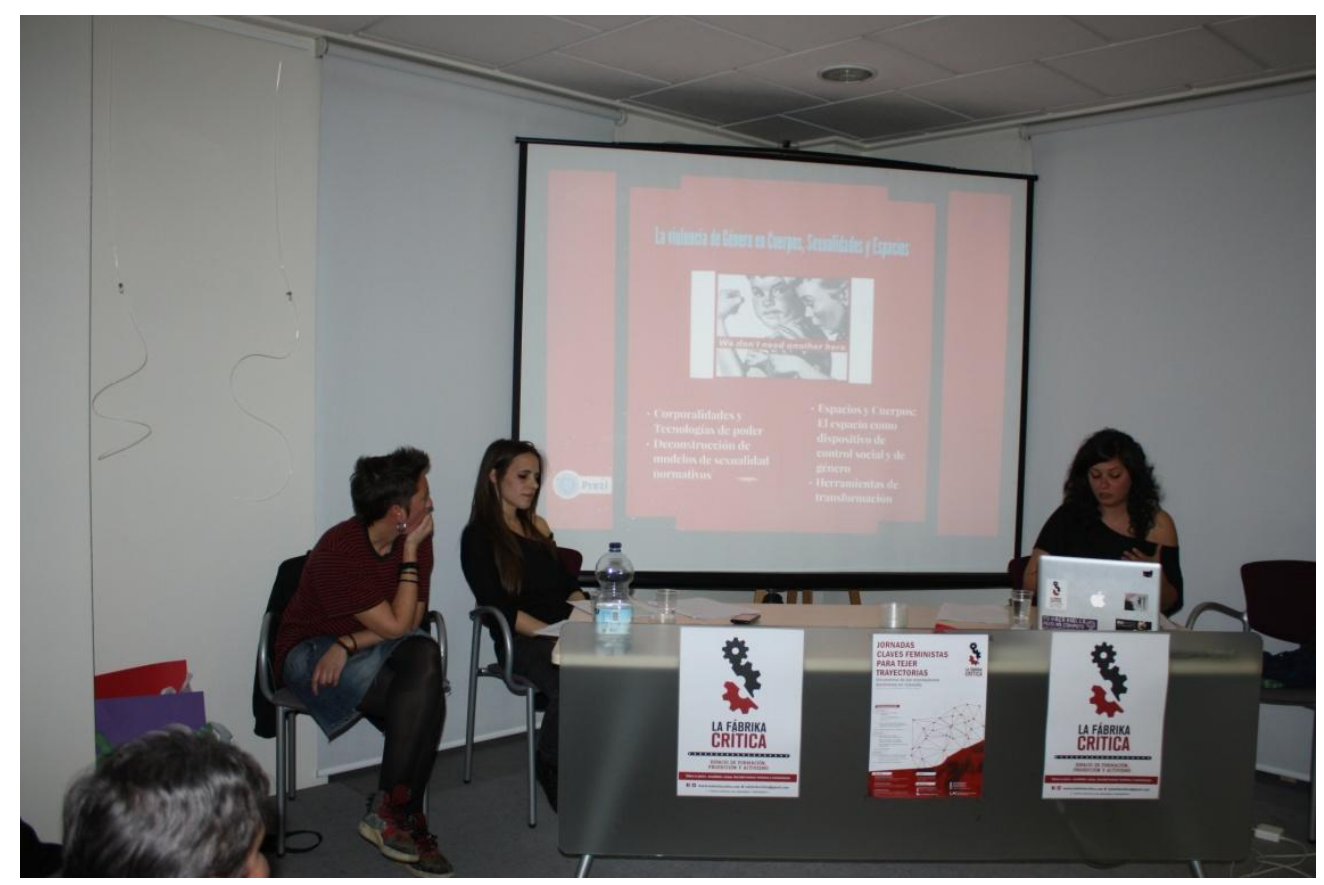

Foto no 37: Jornadas "Claves feministas para tejer trayectorias. Encuentro de los movimientos feministas en Granada" (Febrero 2014) 


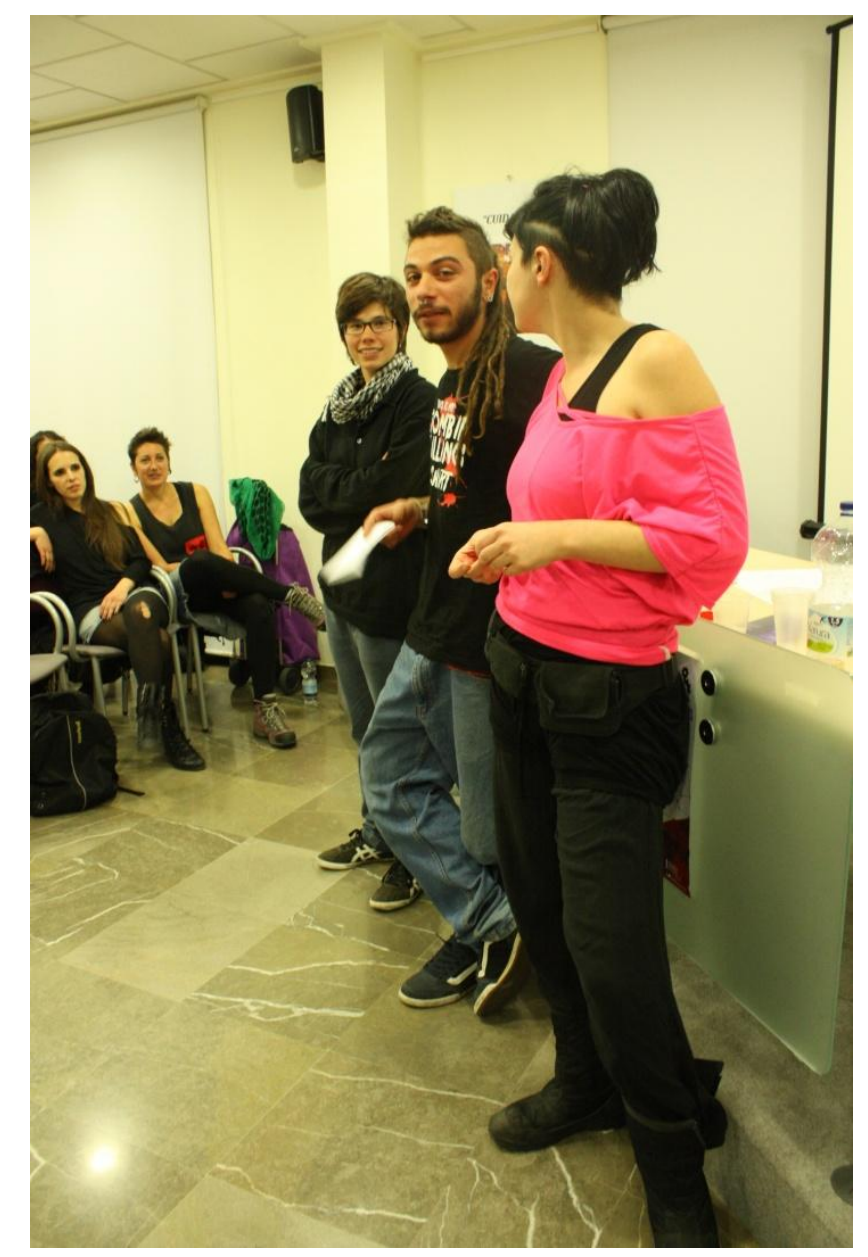

Foto $\mathrm{n}$ ㅇ 38: Jornadas "Claves feministas para tejer trayectorias. Encuentro de los movimientos feministas en Granada" (Febrero 2014)

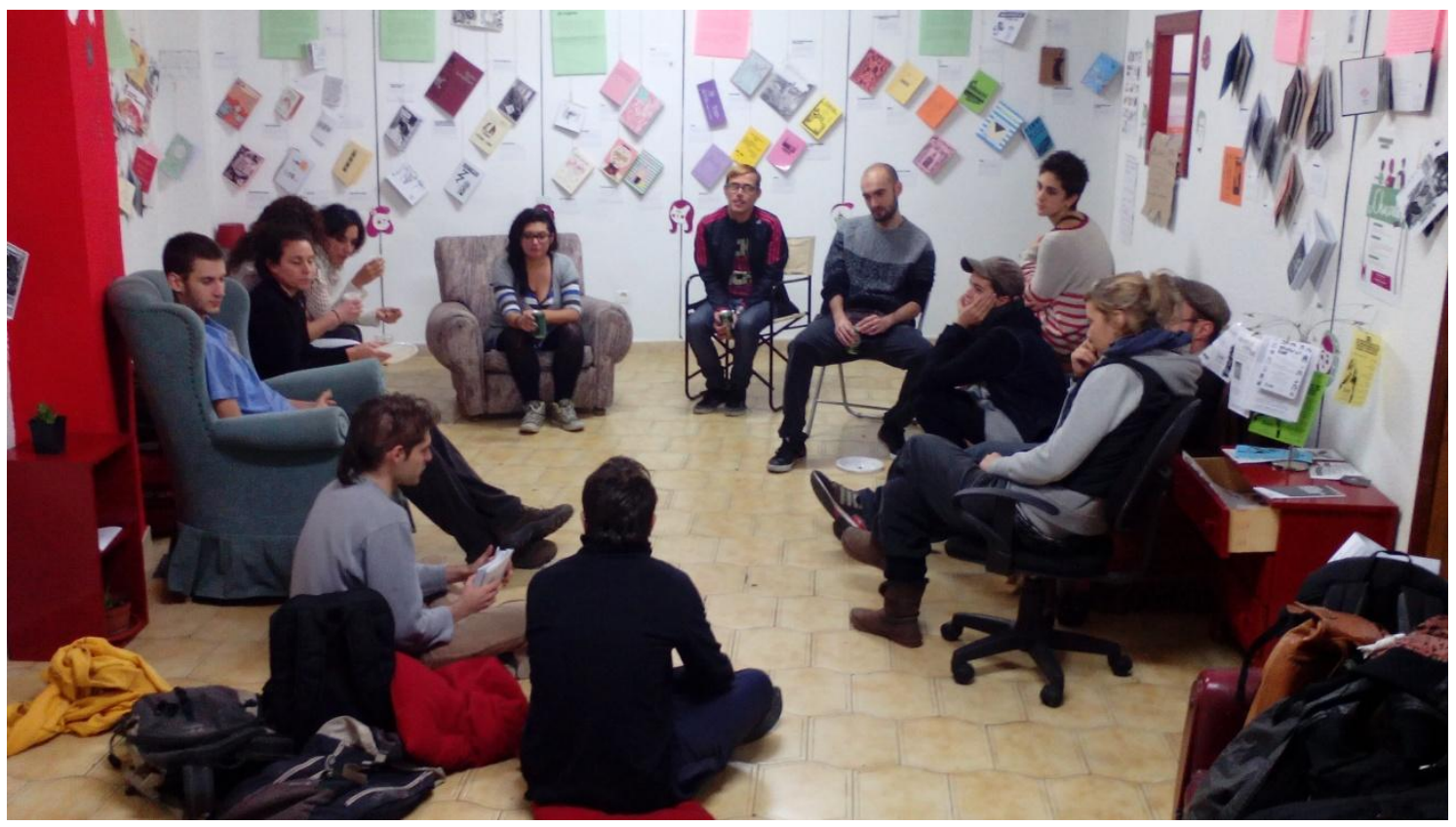

Foto no 39: Espacio de La Fábrika Crítica 


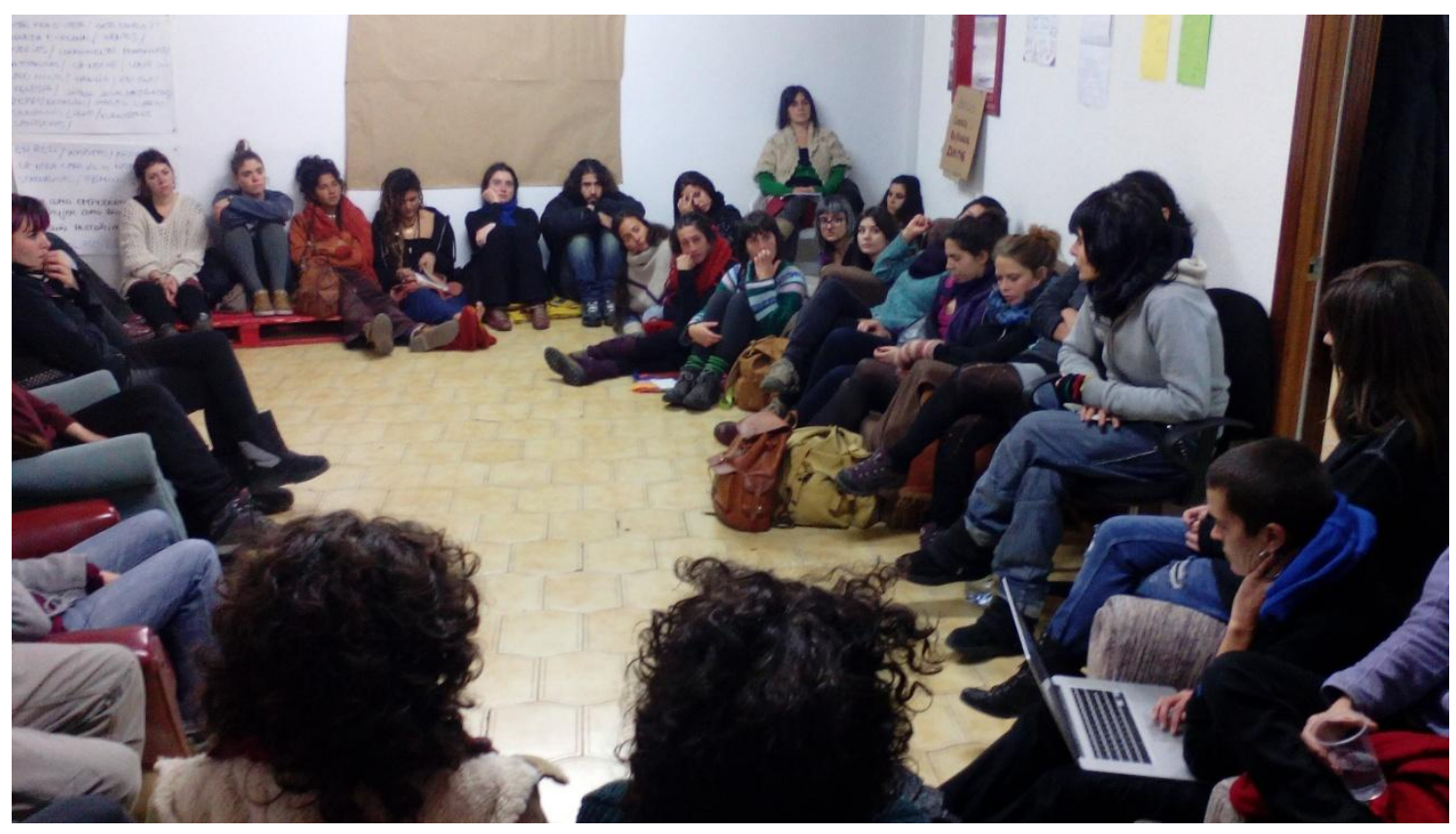

Foto no 40: Espacio de La Fábrika Crítica

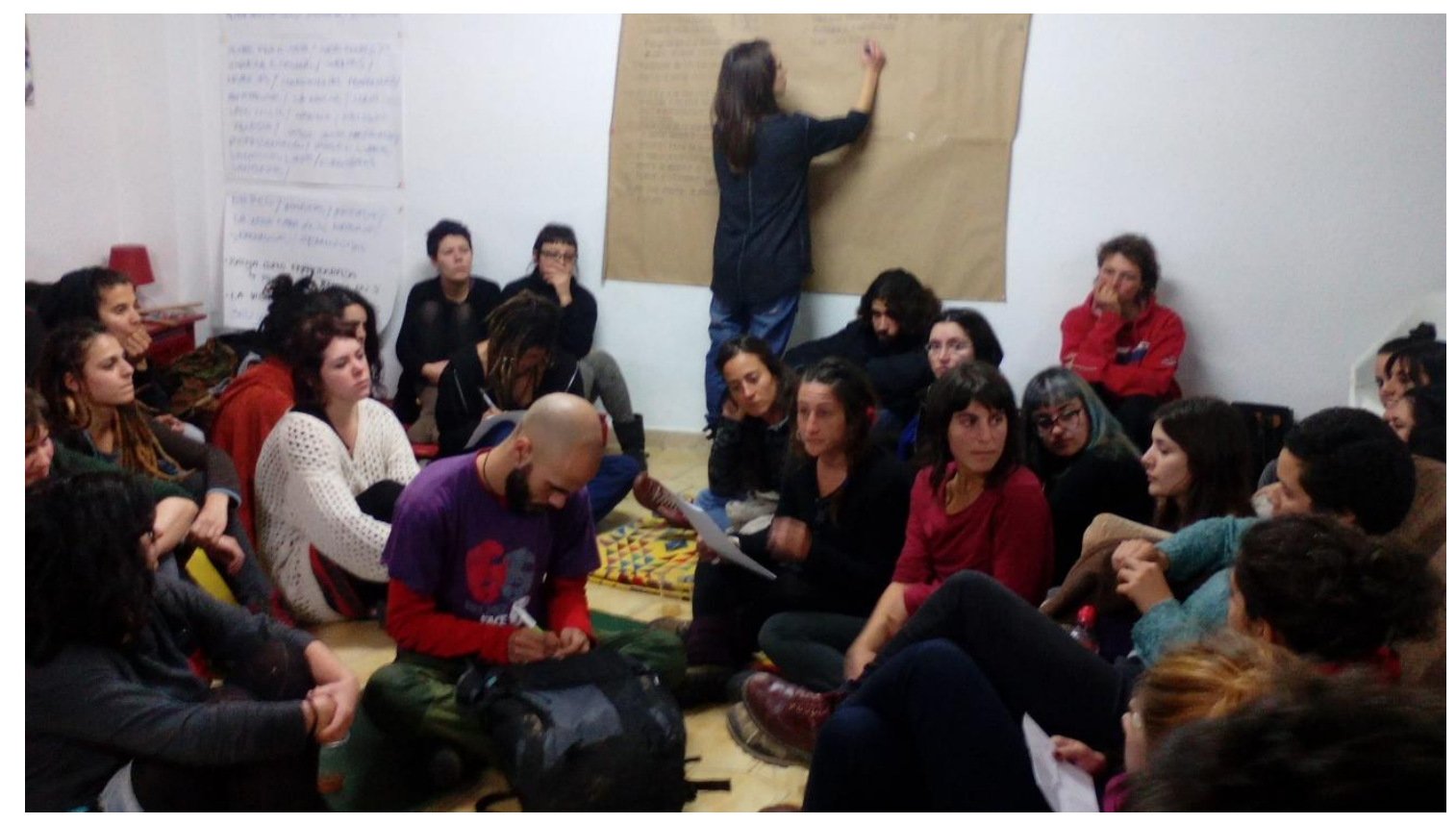

Foto no 41: Espacio de La Fábrika Crítica 


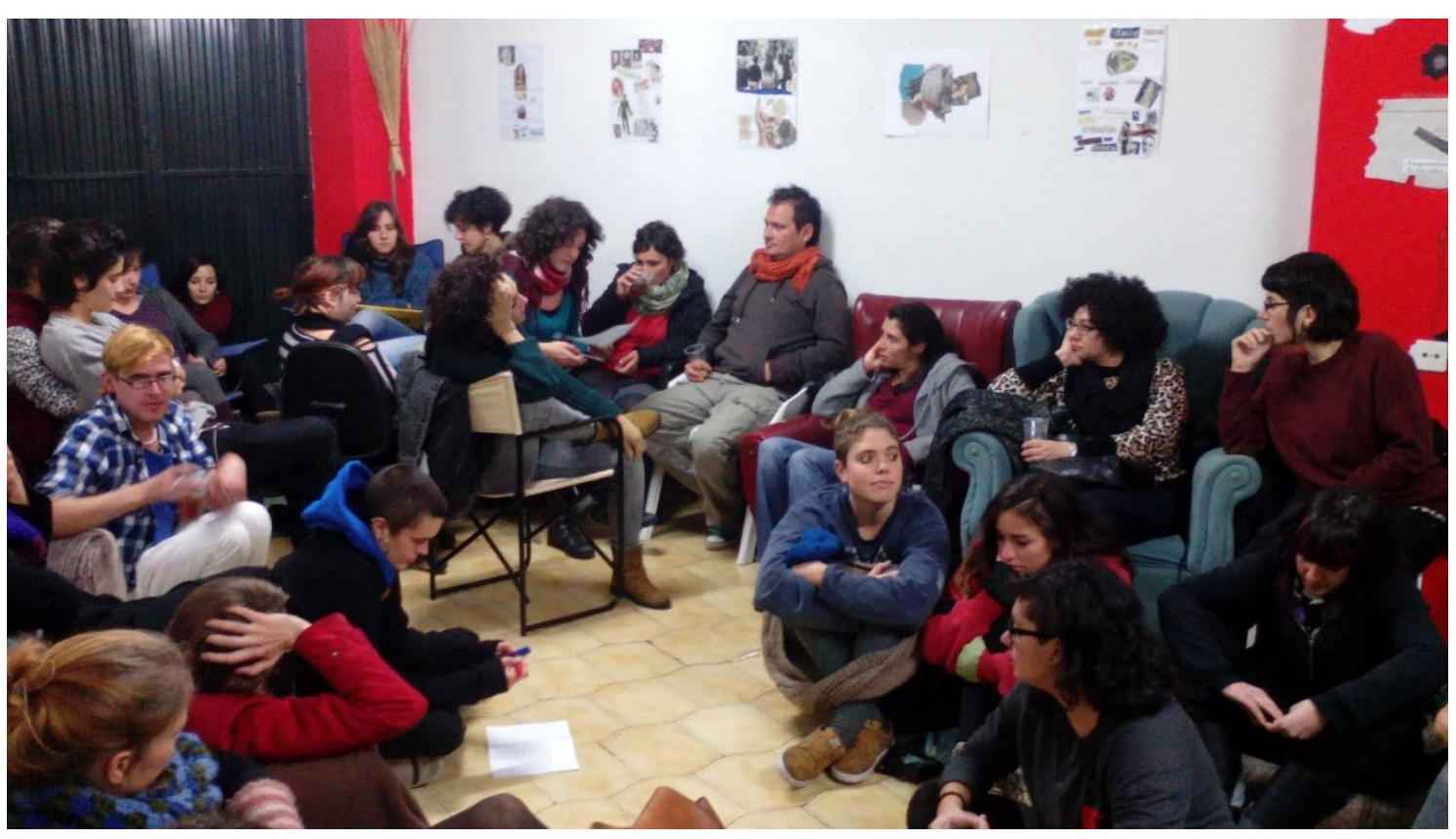

Foto no 42: Espacio de La Fábrika Crítica

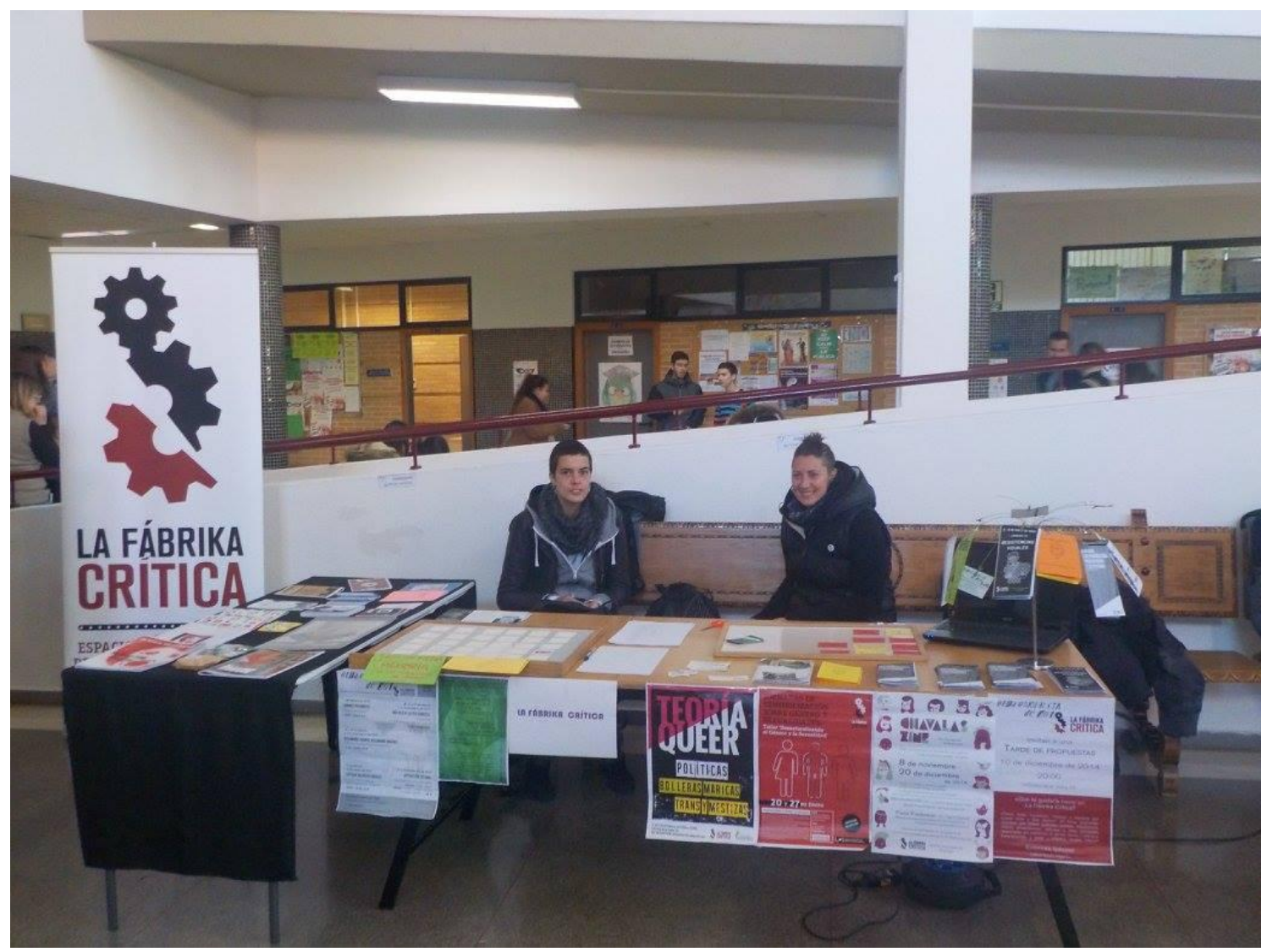

Foto no 43: La Fábrika Crítica y La Otra Eskuelita de Foto 